
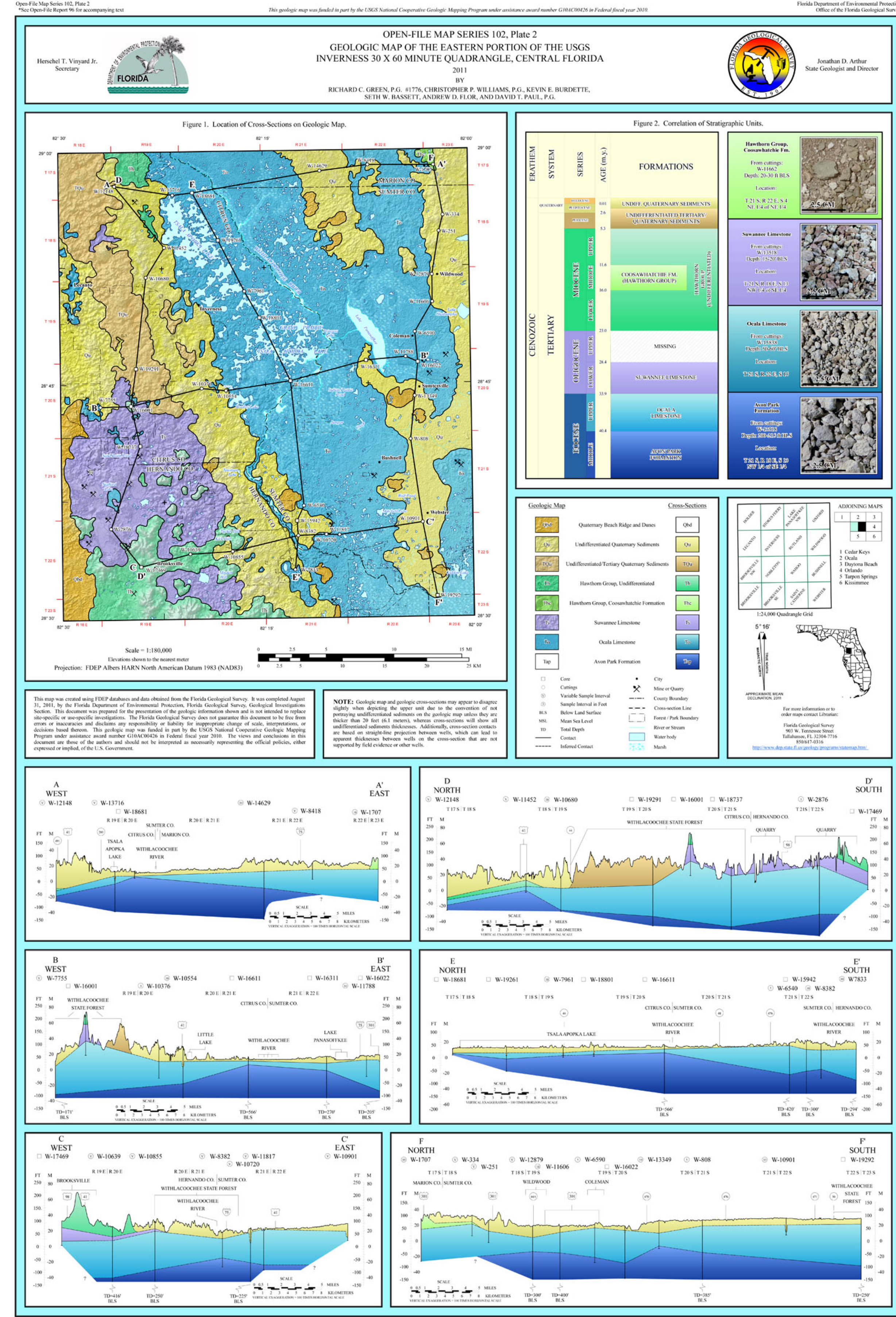


\section{STATE OF FLORIDA}

\section{DEPARTMENT OF ENVIRONMENTAL PROTECTION}

Herschel T. Vinyard Jr., Secretary

\section{LAND AND RECREATION}

Erma M. Slager, Acting Deputy Secretary

\section{FLORIDA GEOLOGICAL SURVEY}

Jonathan D. Arthur, State Geologist and Director
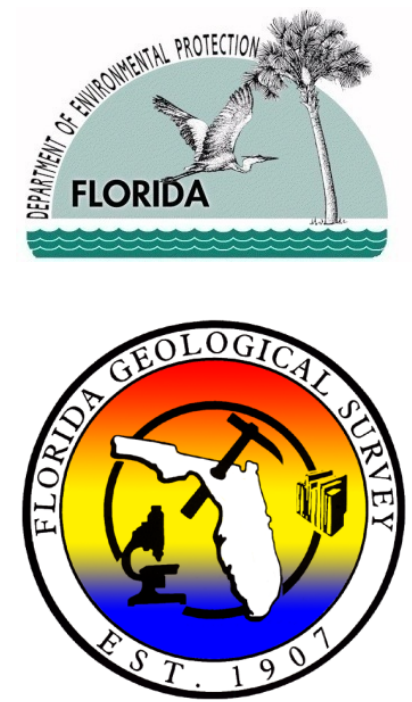

OPEN-FILE REPORT 96

Text to accompany geologic map of the eastern portion of the USGS Inverness 30 x 60 minute quadrangle, central Florida

\section{By}

Christopher P. Williams, Kevin E. Burdette, Richard C. Green, Seth W. Bassett, Andrew D. Flor, and David T. Paul

2011

ISSN (1058-1391)

This geologic map was funded in part by the USGS National Cooperative Geologic Mapping Program under assistance award number G10AC00426 in Federal fiscal year 2010 



\section{TABLE OF CONTENTS}

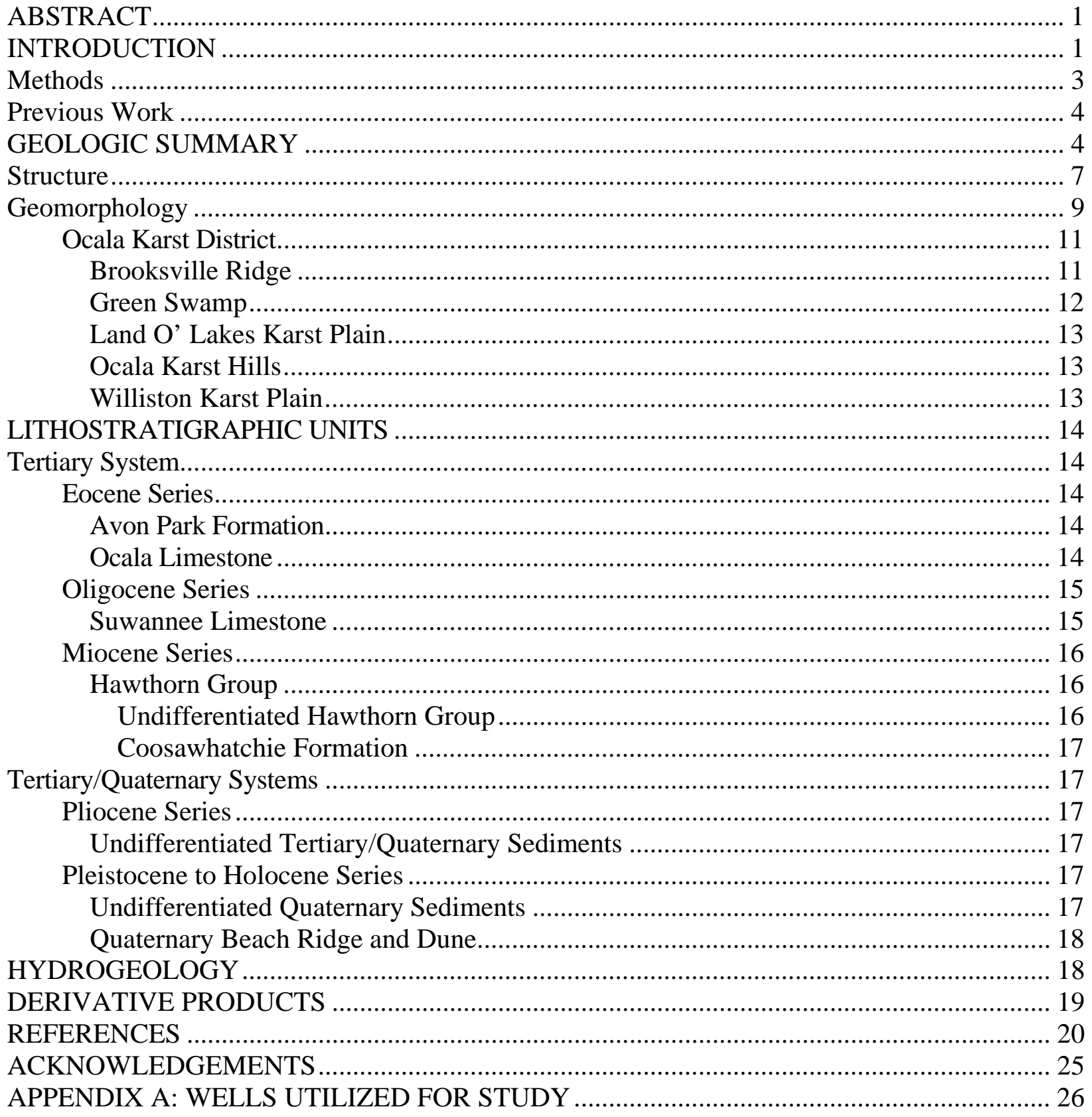

\section{LIST OF FIGURES}

Figure 1. Nearby areas mapped under the FGS STATEMAP Program. .......................................... 2

Figure 2. Location of selected river basins, springs, swallets, and other water bodies. ................... 6

Figure 3. Principal subsurface structures of north Florida............................................................ 8

Figure 4. Terraces in Florida.................................................................................................. 10 



\title{
Text to accompany geologic map of the eastern portion of the USGS Inverness 30 x 60 minute quadrangle, central Florida
}

\author{
Christopher P. Williams (P.G. \#2625), Kevin E. Burdette, Richard C. Green, P.G., \\ Seth W. Bassett, Andrew D. Flor, and David T. Paul, P.G.
}

\begin{abstract}
The accompanying 1:100,000 scale geologic map (Open-File Map Series 102, Plate 1) depicts the areal distribution of bedrock and surficial geologic units for the eastern portion of the USGS Inverness 30 x 60 minute quadrangle. The map was constructed using a combination of field mapping (at 1:24,000 scale), compilation of data from existing maps (various scales), core and cuttings analyses and descriptions, and analyses of various Geographic Information System (GIS) data sources. The resulting data were compiled in ESRI $^{\circledR}$ ArcGIS $^{\circledR}$ ArcMap $^{\mathrm{TM}}$ 9.3.1 software for publication as part of the Florida Geological Survey Open-File Map Series. Mapped units range in age from Upper Eocene to Quaternary. Important resources in the mapped area include groundwater, springs, sand, clay and limestone. Numerous springs, swallets (sinking streams), and other karst features are present in the study area. Understanding of geologic units, karst, springs and their interactions within the area aids urban and land planners, environmental professionals, and citizens in making land-use decisions. Examples include designing new construction projects, siting new water supply wells and energy production facilities, siting waste management and storage facilities, locating sources of mineable resources for aggregate supply, and protection of springs, surface and groundwater quality.
\end{abstract}

Keywords: Florida, geologic map, Ocala Limestone, Suwannee Limestone, Avon Park Formation, Hawthorn Group, geomorphology, hydrogeology, springs, swallets, sinkholes, Floridan aquifer system, Citrus County, Hernando County, Marion County, Sumter County, Brooksville Ridge, Lake Panasoffkee, Tsala Apopka Lake.

\section{INTRODUCTION}

The Florida Geological Survey (FGS) Open-File Report (OFR) 96 accompanies OpenFile Map Series (OFMS) 102, which is comprised of three plates. Plate 1 depicts the near-surface geology of the eastern half of the USGS Inverness 30 x 60 minute quadrangle (U.S. Geological Survey, 1978) on a light detection and ranging (LiDAR) digital elevation model (DEM). Plate 2 depicts six geologic cross-sections, a stratigraphic correlation chart, and representative photos for several of the lithologic units in the study area. Plate 3 is a geomorphology map on a LiDAR DEM, showing locations of known springs, sinkholes and swallets, along with photographs of selected exposures within the study area.

The study area lies south of Ocala, Florida and includes the community of Inverness. It includes portions of Citrus, Hernando, Sumter and Marion Counties (Figure 1). It lies due south of the eastern portion of the USGS Ocala 30 x 60 minute quadrangle, which was previously mapped under the STATEMAP program (Green et al., 2009a). The Withlacoochee and the Little Withlacoochee Rivers and Jumper Creek occur in the map area. Recharge to the Floridan aquifer system occurs over much of the study area, and it is the primary source of springs and drinking water in the region. 

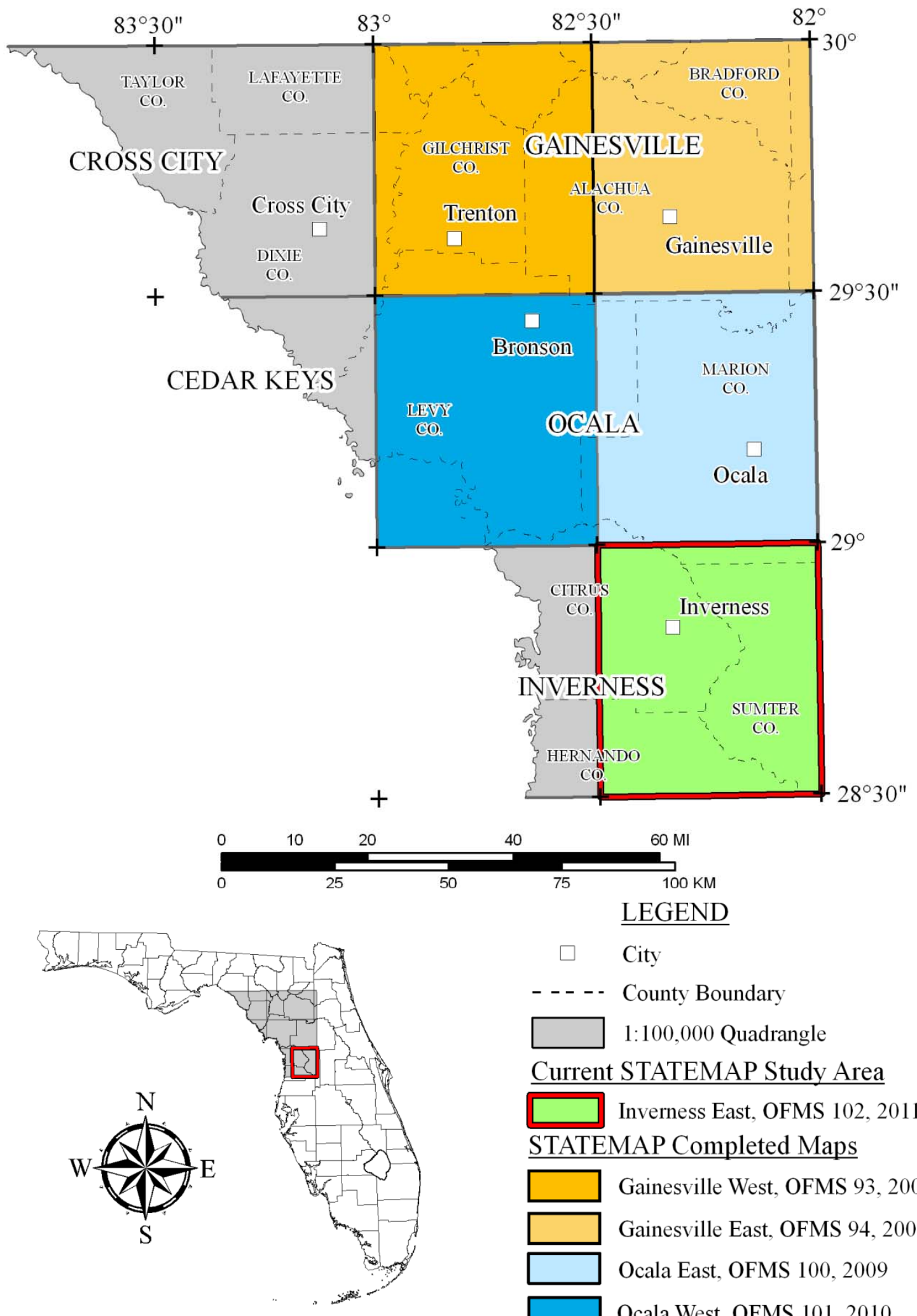

Current STATEMAP Study Area Inverness East, OFMS 102, 2011 STATEMAP Completed Maps प Gainesville West, OFMS 93, 2004 Gainesville East, OFMS 94, 2005 D Ocala East, OFMS 100, 2009

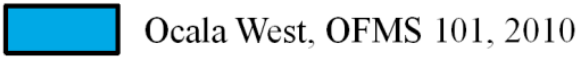

Figure 1. Nearby areas mapped under the FGS STATEMAP Program. 
One objective for this report is to provide basic geologic information for the accompanying OFMS 102. Information provided by this report and the plates in OFMS 102 reaches a diverse audience comprising professionals in geology, hydrology, engineering, environmental and urban planning, and laypersons, all of whom have varying levels of geologic knowledge. The maps can help users identify and interpret geologic features which impact activities related to groundwater quality and quantity, as well as aid in location of mineral resources, land-use planning and construction project design. Applied uses of the maps and data in this report include: 1) identifying potential new mineral resources, 2) characterizing zones of potential aquifer recharge and confinement, 3) aiding water-management decisions on groundwater flow and usage, 4) providing information on aquifer vulnerability to potential pollution, 5) ecosystem, wetlands and environmental characterization and 6) recreational uses.

\section{Methods}

Mapping efforts consisted of 1) reviewing and compiling existing geologic literature and data, 2) mapping geologic units in the field at 1:24,000 scale using standard techniques, 3) analyses of existing core and cuttings samples from the FGS sample repository, 4) new core drilling, 5) collecting and describing outcrop samples and 6) preparing a geologic map, geological cross-sections and geomorphic map of the area. Field work, performed during the fall of 2010 through the summer of 2011, consisted of sampling and describing numerous outcrops, and river and quarry exposures.

In the fall of 2010, the FGS's STATEMAP program undertook upgrading its collection methods for in situ data collection. The mobile GIS package that emerged to meet these requirements is an innovative GIS solution that is easy to use, reliable, low-cost, and highly customizable to the STATEMAP program's needs. A laptop computer with Microsoft ${ }^{\circledR}$ Windows XP operating system, full-sized monitor, and Garmin ${ }^{\circledR}$ GPS unit form the core of the vehiclebased system. Data collection is handled in ESRI's ArcPad ${ }^{\circledR}$, which runs a customized collection of tools that bypass time consuming digital forms and automatically attribute the relevant fields when a new point is added to the map: latitude and longitude; date and time; the type and geologic classification of observation; and the geologist recording the observation. The ease of use of these custom tools is further supplemented by a Logitech ${ }^{\circledR}$ G13, a 25 button keypad operated with the left hand. This piece of hardware allows the user to perform a variety of operations - toggle layers on and off; perform basic operations such as pan, zoom and switching the current ArcPad tool in use - by pressing a single key, rather than navigating multiple onscreen menus and forms; and record a variety of point, line and polygon features of a specific type or class. This ArcPad system quickly allowed us to digitally record the location of float and outcrop as well as other features that aided with geologic mapping.

Sixty-five new samples of geologic material were added to the FGS surface-sample archives (M-Series) and four cores (674 feet or 205.3 meters total) were drilled. Approximately 100 outcrops and exposures were also examined during this project. All data, including over 500 wells from the study area and bordering 7.5 minute quadrangles, were compiled and analyzed by the authors. Appendix A includes both FGS wells within the study area boundary and Water Management District well data points with top of limestone/dolostone rock information. An interpolated top of rock surface was developed using kriging along with a LiDAR derived DEM to generate an overburden thickness model. The map and accompanying plates were developed in ESRI $^{\circledR}$ ArcGIS $^{\circledR}$ ArcMap $^{\text {TM }}$ 9.3.1 software for publication as part of the FGS OFMS. 
Much of the study area is blanketed by a veneer of undifferentiated Tertiary and Quaternary sediments and soils. For this reason, and in keeping with geologic mapping practices developed by Scott et al. (2001), the authors have adopted the policy of mapping the first named geologic unit within 20 feet (6.1 meters) of the surface. If undifferentiated Tertiary/Quaternary (TQu) or undifferentiated Quaternary (Qu) sediments attain a thickness greater than 20 feet (6.1 meters), then they appear as the mapped unit. If these undifferentiated sediments are less than 20 feet (6.1 meters) thick, then the underlying lithostratigraphic unit appears on the map.

The region is generally vegetated, and public access in parts of the mapped area is hindered by the presence of numerous wetlands, farms, ranches and privately owned land. The authors had to rely on existing well and core data in these areas. Fieldwork access was typically limited to public roads, State-owned lands, County-owned lands, and Southwest Florida Water Management District-owned lands.

\section{Previous Work}

The current study builds on many previous geologic investigations in and around the present map area which were useful in preparing this report. A regional study of the geology of Citrus and Levy Counties was conducted by Vernon (1951) and is the baseline study for the current study area. Preliminary county geologic maps for Citrus (Campbell and Scott, 1992), Sumter (Campbell, 1993a), Hernando (Campbell, 1993b) and Marion (Scott, 1992) Counties at 1:126,720 scale were previously published by the FGS. However, each of these OFMS geologic maps were constructed in an average time-frame of two weeks utilizing selected in-house geologic data with little-to-no extra field work. Although these maps provided a starting point for the detailed geologic mapping undertaken for this project, significant refinement of prior geologic maps was possible as a result of this project. A statewide geologic map (Scott et al., 2001) was published by the FGS in digital format and provided a framework for the current, more detailed mapping. A structure-contour map of the top of the Floridan aquifer system (Allison et al., 1995; Arthur et al., 2008), and an isopach map of the Hawthorn Group in the region (Groszos and Rupert, 1992; Arthur et al., 2008) also proved useful.

This study benefited greatly from the work performed during geologic mapping of the USGS Ocala 30 x 60 minute quadrangle (Green et al., 2009a; Green et al., 2009b; Green et al., 2010; Williams et al., 2010). Some of the field relationships and stratigraphic problems were worked out during those projects and data gathered during those projects proved invaluable to the completion of this project.

\section{GEOLOGIC SUMMARY}

The near surface geology of the eastern portion of the USGS 30 x 60 minute Inverness quadrangle is composed of a complex mixture of Middle Eocene to Quaternary carbonate and siliciclastic sediments. A combination of factors, including fluvio-deltaic deposition, marine deposition, dissolution of underlying carbonates, erosion of sediments as a result of eustatic changes in sea level and structural features have influenced the geology of the study area.

Distinction between the Middle Eocene Avon Park Formation and the unconformably overlying unit, the Upper Eocene Ocala Limestone, is at times difficult in the study area. Dolomitization of the Avon Park Formation and common recrystallization of the lowermost Ocala Limestone has significantly altered the original rock lithology and fabric. Fossil indicators 
are only somewhat helpful because the latest deposits of the Avon Park Formation and the earliest deposits of the Ocala Limestone are both bank assemblages, consistent with deposition in a shallow-water limestone bank or plateau, not unlike the present day Bahama Bank (Bryan, 2004). Karst development on the surface of the Avon Park Formation and later the Ocala Limestone, in addition to regional erosion over the Ocala Platform, has left an undulatory contact that does not allow clear definition of regional outcrops based upon elevation. A modern analog is evident along the Waccasassa Bay and Withlacoochee Bay shorelines where modern islands of Ocala Limestone with elevations rarely more than 5 feet (1.5 meters) above MSL exist in shallow flats where water depths are typically less than 3 feet (0.9 meters) (Green et al., 2010; Plate 3, Photos 1 and 3).

Rarely, the Upper Eocene Ocala Limestone is missing entirely from the rock section and the Middle Eocene Avon Park is unconformably overlain by the Lower Oligocene Suwannee Limestone. In the study area, this was most notable at Jordan Sink in the Two Mile Prairie Tract of the Withlacoochee State Forest. This feature is located in the northeastern part of the USGS Holder 7.5 minute quadrangle. Most often, when the Suwannee Limestone is present, it is underlain by the Ocala Limestone. These two formations can both vary from wackestone to grainstone. Aside from several diagnostic foraminifera and echinoids, these limestones can be difficult to differentiate in cores or cuttings. At times, such as seen in Photo 1 of OFMS 102; Plate 3, there is a distinct contact between the two formations; however, this is not always (or even usually) present. The key distinction of Suwannee Limestone from Ocala Limestone is that there are some microfossil assemblage similarities between the Suwannee Limestone and the Avon Park Formation that are not similar to the Ocala Limestone. Both of the former contain Fallotella sp. which is only found infrequently at the base of the Ocala Limestone (personal communication, Jonathan Bryan). These units contain Discorinopsis sp. which is not found in the Ocala Limestone. The occurrence of Nummulites sp. and Lepidocyclina sp. in the Ocala Limestone distinguish it from the Suwannee Limestone and the Avon Park Formation.

The Hawthorn Group occurs in the southwestern portion of the study area as hilltops of weathered sandy clays and clayey sands. The presence of these siliciclastics is hypothesized by the authors to have effectively capped and hindered dissolution of the underlying limestones. Where the Miocene undifferentiated Hawthorn Group sediments are present, the Lower Oligocene Suwannee Limestone and/or Upper Eocene Ocala Limestone reside at a higher elevation relative to surrounding areas without Hawthorn sediments. The Middle Miocene Coosawhatchie Formation of the Hawthorn Group is present in the northeastern part of the study area in a few remnant hills at the southern end of the Ocala Karst Hills geomorphic province (OFMS 102; Plate 1 and OFMS 102; Plate 3, Figures 1 and 3).

Much of the eastern portion of the Inverness quadrangle is located within the South Withlacoochee River basin with part in the Oklawaha River and Crystal River to St. Petersburg basins (Figure 2). Within the study area, these rivers and their tributaries contain several documented springs (Scott et al., 2004). A first magnitude spring is defined as having a minimum average flow of 100 cubic feet per second, or 64.6 million gallons per day (Copeland, 2003). Many of these springs have shown significant increases in pollutants in the last few decades, particularly nitrate (Phelps, 1994; Phelps, 2004; Jones et al., 1996; Scott et al., 2002; Upchurch et al., 2004; Copeland et al., 2009). Detailed geologic mapping of lithostratigraphic units in this area provides critical data needed for future assessments of the vulnerability of the aquifer systems and springs to contamination. The recharge areas for many springs are located 


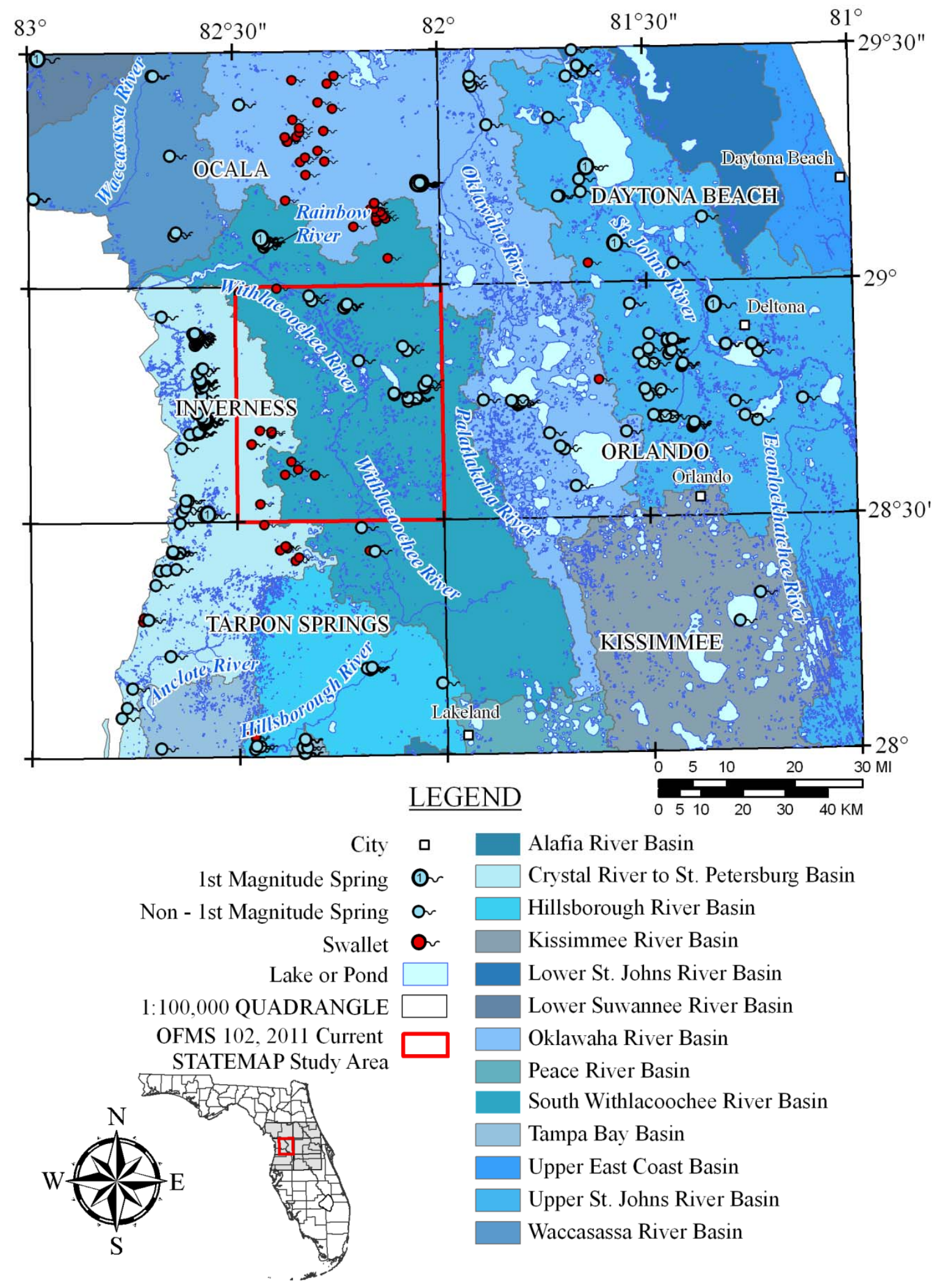

Figure 2. Location of selected river basins, springs, swallets, and other water bodies. 
within and nearby the current study area. Understanding the surficial geology of the map area is a key factor in developing management and protection plans, not only for the springs, but for the unconfined portions of the Floridan aquifer system.

A recent report on Lake Panasoffkee by the USGS studied groundwater input to the lake. McBride et al. (2011) determined that spring and groundwater discharge to Lake Panasoffkee is equivalent to a first magnitude spring. The low transmissivity values in the Upper Floridan aquifer system, noted in southern Levy County by Bush and Johnson (1988), match areas where the Avon Park Formation and/or highly recrystallized lowermost Ocala Limestone crop out at the surface. The trend of shallow depth to the Avon Park Formation continues southeast from Levy County along the Ocala Platform to the region encompassed by Tsala Apopka Lake. The authors of this present study hypothesize that the location of the Tsala Apopka Lake above the shallow Avon Park Formation on the southeastern portion of the Ocala Platform is largely influenced by the low transmissivity of the Avon Park Formation. The shallowing of the depth to the Avon Park Formation also appears to be a major factor in the trends of groundwater flow and age of water that flows into Lake Panasoffkee. A comprehensive study of the details of groundwater flow into Lake Panasoffkee, from which the former hypothesis is postulated, may be found in McBride et al. (2011).

\section{Structure}

Several structural variables have affected the geology of the region (Figure 3). The Peninsular Arch, a structurally high area which affected deposition from the Cretaceous to the early Cenozoic, is the dominant subsurface feature of the Florida peninsula (Applin and Applin, 1944; Applin, 1951; Puri and Vernon, 1964; Williams et al., 1977; Schmidt, 1984; Miller, 1986; Scott, 1997). The axis of the Peninsular Arch, which lies to the east of the study area, extends from southeastern Georgia to the vicinity of Lake Okeechobee in southern Florida in a general northwest to southeast trend. The crest of the arch passes beneath Alachua County and is highest in Union and Baker Counties north of the study area. The arch was a topographic high during most of the Cretaceous Period and had Upper Cretaceous sediments deposited upon it (Applin, 1951). It formed a relatively stable base for Eocene carbonate deposition (Williams et al., 1977). The arch did not affect mid-Tertiary to Holocene sediment deposition (Williams et al., 1977; Scott, 1997).

The Ocala Platform is the most prominent structure affecting the near surface depositional and post-depositional environments within the map area. Hopkins (1920) originally named this feature the Ocala Uplift. Vernon (1951) described the Ocala Uplift as a gentle flexure developed in Tertiary sediments with a northwest-southeast trending crest. Because there is continuing uncertainty about the origin of this feature, Scott (1988) used the term Ocala Platform, rather than Ocala Uplift or Ocala Arch, since it does not have a structural connotation.

The Ocala Platform, which underlies the current study area, influenced late Tertiary sediment deposition. Miocene sediments of the Hawthorn Group are thought to have been deposited across the platform (Scott, 1981a; Scott, 1988; Scott, 1991a). Post-Miocene erosion has removed sediments of the Hawthorn Group from much of the crest of the Ocala Platform, exposing Eocene and Oligocene carbonates (Cooke, 1945; Espenshade and Spencer, 1963; Scott, 1981b). This is evident throughout much of the central portion of the map area (OFMS 102; Plate 1). Undifferentiated sediments, thickest over the western and eastern portion of the study 
area, have subsequently been deposited on the exposed Eocene carbonates. These consist of residual clays, sands, and aeolian sands deposited during the Miocene to Holocene (Scott, 1997).

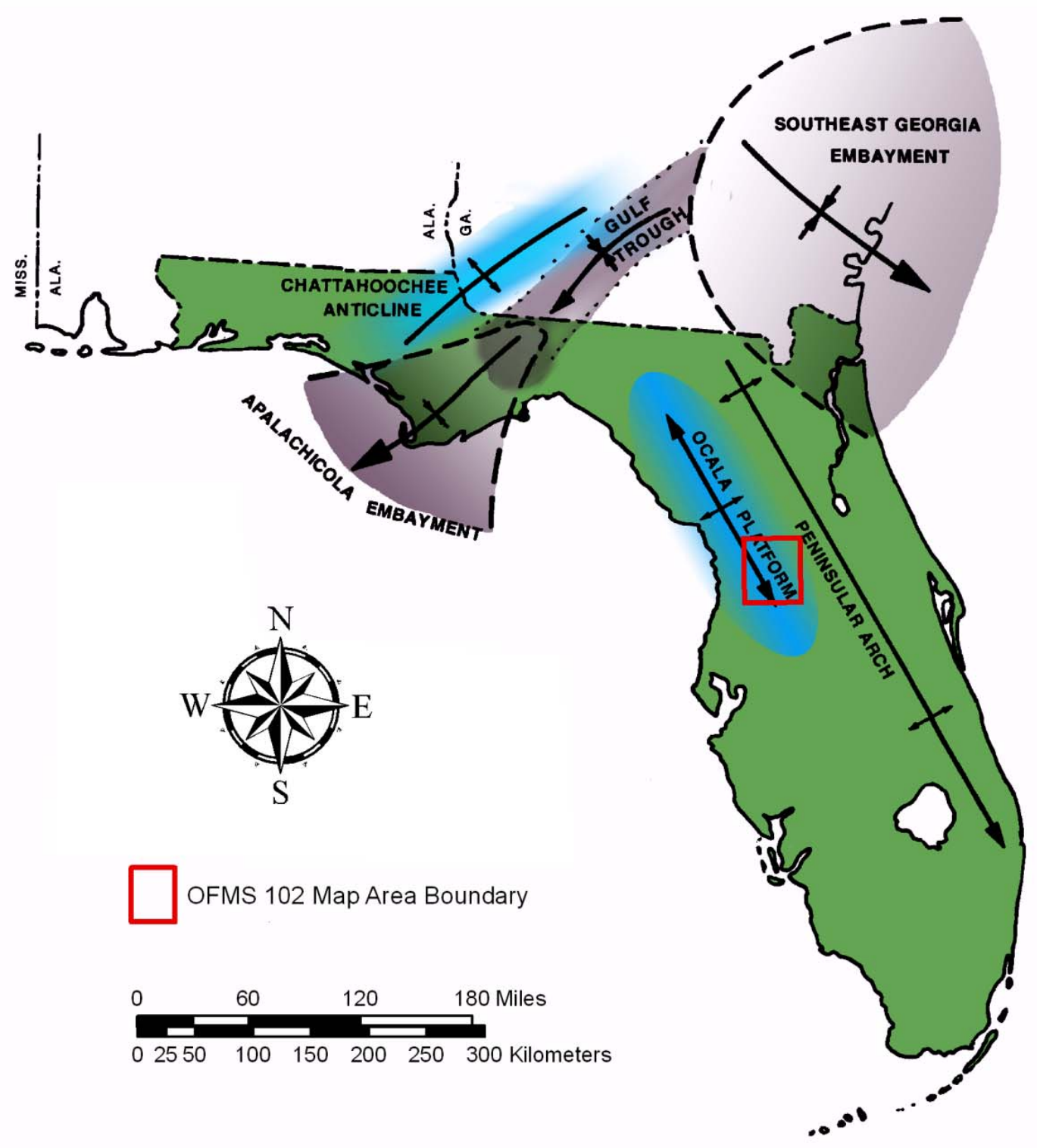

Figure 3. Principal subsurface structures of north Florida (modified from Puri and Vernon, 1964 and Schmidt, 1984). 
Vernon (1951), utilizing aerial photographs, mapped fracture patterns throughout northern peninsular Florida. Regionally, these fractures generally trend parallel to the axis of the Ocala Platform in a northwest-southeast orientation. A secondary system of fractures intersects these primary fractures at high angles in a northeast-southwest trend (Vernon, 1951; see p. 47-52 for discussion of fractures). Orientation of stream meanders along portions of the Withlacoochee River suggests that these fracture patterns may be a controlling factor in stream location.

Vernon (1951) also discussed the occurrence of faults in part of the Florida peninsula. He attributed the origin of the faults to his postulated uplift of the Ocala Platform (his Ocala Uplift). Although he described the occurrence and surface-strike orientation of the faults, there was no discussion of the dip of the faults. Vernon did mention that his postulated faults were very steeply inclined. Vernon (1951) also mentioned seeing slickensides and grabens in quarries in the study area. Similar features have been observed by several of the authors of this publication while doing fieldwork in the region. It is believed that these are related to karst collapse and localized block movement within karst features, not to faulting as Vernon (1951) suggested. When a cover collapse sinkhole forms, large blocks may move downward along fractures created by the collapse and create localized slickensides which are not related to structural faulting. Additionally, numerous wells that Vernon (1951) used for cross-sections, which depicted faults in his report, were investigated by Green et al. (2009b) and several wells were deemed to be karst features. For example, W-1198 (see Vernon, 1951; Figure 14), appears to be karst infill. Karst features in the study area are very common (OFMS 102; Plate 3, Photo 4).

A secondary critique of the faulting described by Vernon (1951) is the fact that many of the purported faults are actually offsets between biozonations within a formation, such as the Avon Park Formation, or between members of what Vernon (1951) called the Moodys Branch Formation (now Ocala Limestone; Puri, [1957], Scott, [1991b]). Through analyses and interpretation of hundreds of wells in the USGS Ocala and Inverness 30 x 60 minute quadrangles, the present authors recognize that there is great variability in the Ocala Limestone and the Avon Park Formation that is in large part related to original environments of deposition. Therefore, any faulting inferred based upon lithologic differences within the Avon Park Formation and Ocala Limestone are more likely variations due to environmental facies, not that these formations have distinct horizontal beds that are continuous and contiguous throughout the entire formation. It has already been discussed that the unconformable contact of the Avon Park Formation and the Ocala Limestone is not a planar surface, but formed on a topographically variable, karstified surface. Thus, adjacent localities where Ocala Limestone and Avon Park Formation are at the same elevation do not require a structural solution.

\section{Geomorphology}

Healy (1975) recognized six possible marine terraces within the study area (Figure 4) based upon elevation: the Talbot terrace at elevations between 25 and 42 feet (7.6 and 12.8 meters) above mean sea level (MSL), the Penholoway terrace at elevations between 42 and 70 feet (12.8 and 21.3 meters) above MSL, the Wicomico terrace at elevations between 70 to 100 feet (21.3 to 30.5 meters) above MSL, the Sunderland/Okefenokee terrace at elevations between 100 and 170 feet (30.5 and 51.8 meters) above MSL, the Coharie terrace at elevations between 170 and 215 feet (51.8 and 65.5 meters) above MSL, and Hazelhurst terrace at elevations between 215 and 320 feet (65.5 and 97.6 meters) above MSL. Detailed discussions and correlations of these marine terraces and relict shorelines have been attempted by many authors, 
including Matson and Sanford (1913), Cooke (1931, 1939), Flint (1940, 1971), MacNeil (1950), Alt and Brooks (1965), Pirkle et al. (1970), Healy (1975), and Colquhoun et al. (1991).

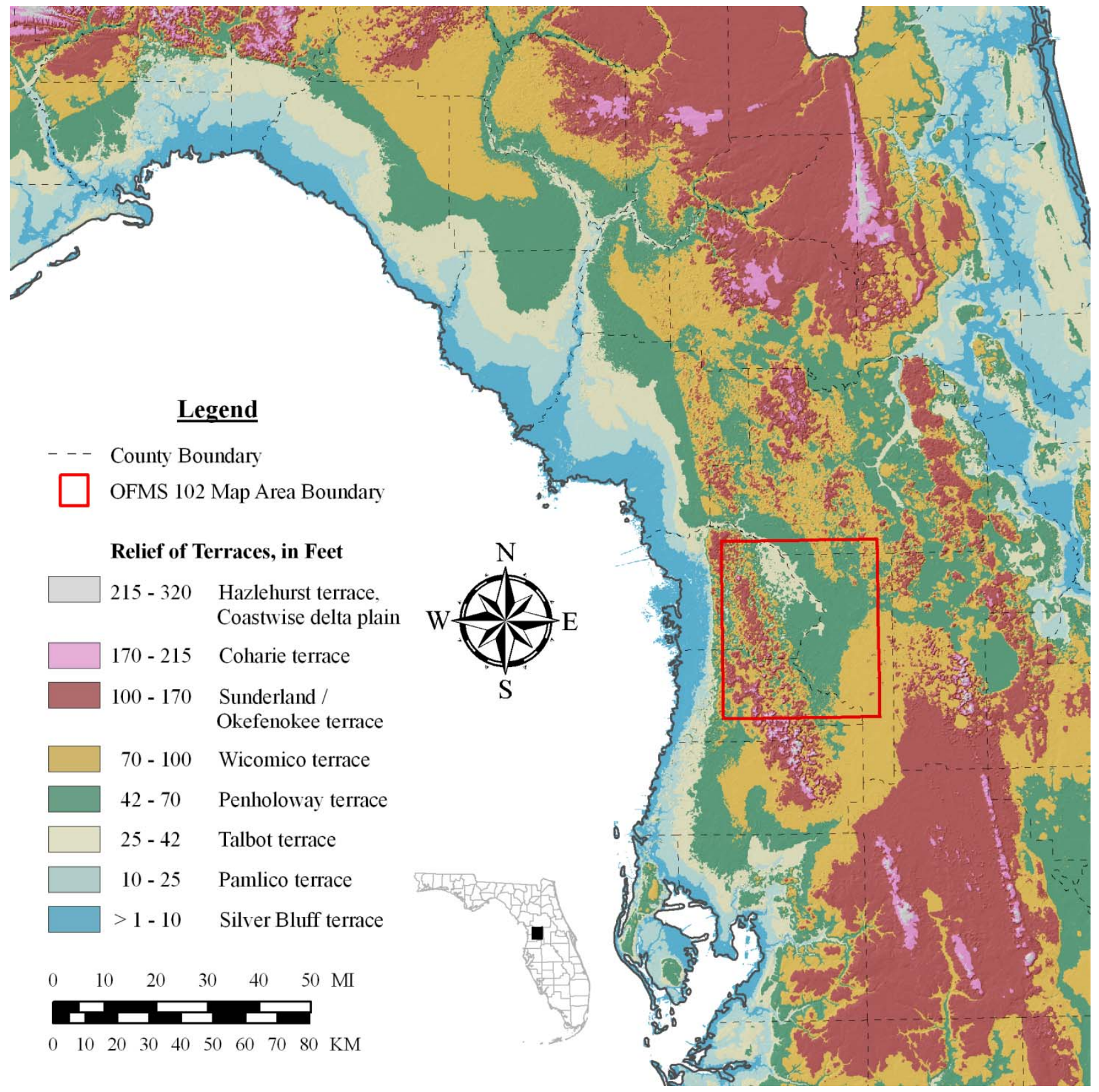

Figure 4. Terraces in Florida (after Healy, 1975). 
The terrace associated with the Brooksville Ridge is best related to the Penholoway, but the elevations of the Brooksville Ridge suggest that it may have formed at some earlier, higher sea level and the present terrace at the western toe is a later geomorphic event that modified the western flank of the ridge. White (1970) inferred by its elevation that the Brooksville Ridge must be related to the Wicomico with sea level over 100 feet (30.5 meters) above MSL. However, White (1970) also noted that the Brooksville Ridge has "suffered so much differential subsidence from solution of underlying limestone that it is difficult to correlate." Isostatic rebound initiated by carbonate dissolution further complicates tracing elevationally delineated features in Florida (Opdyke et al., 1984; Adams et al., 2010).

According to Scott et al. (in preparation), the study area is entirely within the Ocala Karst District (OFMS 102; Plate 3, Figure 2). Within the map area, the Ocala Karst District has been further subdivided topographically into five regional physiographic provinces: Brooksville Ridge, Green Swamp, Land O’ Lakes Karst Plain, Ocala Karst Hills and Williston Karst Plain.

\section{Ocala Karst District}

The Ocala Karst District encompasses a broad area from central Wakulla County in the panhandle of Florida, south to Hillsborough and Pinellas Counties in the west-central peninsula and inland to nearly the center of the peninsula (OFMS 102; Plate 3, Figures 2 and 3). Elevations within the district range from sea level along the Gulf of Mexico coast to a maximum of 300 feet (91.4 meters) above MSL on the Brooksville Ridge. Within the study area, elevations range from 4 feet (1.2 meters) to 271 feet (82.6 meters) above MSL in the southwest portion of the map area at the southern end of the Brooksville Ridge in Hernando County.

Carbonate sediments of the Middle Eocene Avon Park Formation, the Upper Eocene Ocala Limestone and Lower Oligocene Suwannee Limestone lie at or near the land surface in this district within the study area. There also exist Miocene undifferentiated Hawthorn Group and undifferentiated Tertiary/Quaternary sediments, particularly associated with the Brooksville Ridge. The northeastern portion of the study area has limited outcrops of Middle Miocene Hawthorn Group Coosawhatchie Formation sediments. The Ocala Karst District is dominated by sinkholes and shallow bowl-shaped depressions, producing a rolling topography. Generally, a variably permeable siliciclastic cover allows downward percolating groundwater to slowly dissolve the underlying limestone, leading to cover-collapse sinkholes and cover-subsidence features (Sinclair and Stewart, 1985). Cover-collapse sinkholes form rather abruptly from the structural failure of an underlying cavern roof. An excellent example of this is at Devil's Millhopper Geological State Park, located in Alachua County north of the present study area (Evans et al., 2004).

Cover subsidence features generally occur in areas where sediments sag as carbonates dissolve underneath. Typically, areas such as these have shallow sinks formed by the downward raveling of the siliciclastic overburden filling voids created by slow dissolution of underlying carbonates or by slow dissolution of the carbonate surface. Springs, sinking (swallets) and resurgent streams, and caverns commonly occur within the Ocala Karst District.

\section{Brooksville Ridge}

The Brooksville Ridge, described by White (1970) as "the most massive of the ridges which rise above the general level of the Central Upland", stands out in stark contrast to the surrounding 
karst plains. The Brooksville Ridge province encompasses most of the western portion of the study area (OFMS 102; Plate 3, Figures 1 and 3). It is separated into two sections (northern and southern) by the Withlacoochee River. The northern portion of the Brooksville Ridge begins in Gilchrist and Alachua Counties and terminates in Levy and Marion Counties. The southern portion extends from Citrus County southward into Pasco County.

The two sections of the ridge differ in elevation, length-to-width ratio and underlying geology. Elevations in the northern, narrower portion of the Brooksville Ridge range from approximately 50 feet (15.2 meters) to greater than 150 feet (45.7 meters) above MSL. Elevations in some sinkholes are less than 50 feet (15.2 meters) above MSL. The southern, broader part of the ridge ranges in elevation from approximately 50 feet (15.2 meters) to more than 300 feet (91 meters) above MSL. In a few sinkholes, elevations of approximately 10 feet (3 meters) above MSL occur. Within the study area, elevations in this province range from 5 feet (1.5 meters) to 270 feet (82.3 meters).

The topography of the Brooksville Ridge displays significant variability. The northern section has low, rolling karst hills interspersed with moderately shallow sinkholes. The southern portion of the ridge becomes progressively hillier and terrain relief increases from north to south. White (1970) describes the southern ridge area as having "the most irregular surface to be found in any area of comparable size in peninsular Florida." From the vicinity of Brooksville southward, the hills are higher and more closely spaced. North of Brooksville, the hills are more widely spaced and generally have lower elevations, an indication of more mature karst. The Brooksville Ridge is well drained with wet conditions existing only in the low lying karst features. There are no springs found on the ridge, but many swallets occur within the southern Brooksville Ridge.

The Upper Eocene Ocala Limestone underlies the northern portion of the Brooksville Ridge. Weathered Miocene undifferentiated Hawthorn Group sediments lie unconformably on the Ocala Limestone with undifferentiated Quaternary and/or Tertiary/Quaternary siliciclastics mantling the ridge. The southern portion of the Brooksville Ridge is more complex geologically than the northern section. The southern section of the Brooksville Ridge is present in the western third of the mapped area (OFMS 102; Plate 3, Figures 1 and 3). The province is underlain by carbonates of the Middle Eocene Avon Park Formation, the Upper Eocene Ocala Limestone and the Lower Oligocene Suwannee Limestone which are overlain by variable thicknesses of weathered Miocene undifferentiated Hawthorn Group sediments and undifferentiated Tertiary-Quaternary siliciclastics, Quaternary siliciclastics or relict dunes of the Quaternary Beach Ridge and Dune map unit.

\section{Green Swamp}

The Green Swamp province occupies parts of Hernando, Pasco, Sumter, Lake, Polk and Hillsborough Counties. It is bounded on the north by the Williston Karst Plain, on the west by the Brooksville Ridge and Land O' Lakes Karst Plain, on the south and east by the Lakeland-Lake Wales Ridge Complex, part of the Central Lakes District, and on the south by the Polk-DeSoto Plain, part of the Sarasota River District (OFMS 102; Plate 3, Figure 3). The entire area is very poorly drained and swampy conditions prevail due to the high potentiometric surface of the Floridan aquifer system. Elevations of the Green Swamp range from 39 feet (11.9 meters) to 197 feet (60 meters). Within the study area, elevations range from less than 70 feet (21.3 meters) in the southwest to 100 feet (30.1 meters) in the eastern part of the swamp. Few areas of sand dunes are found in the swamp. Karst features are common throughout Green Swamp but there are few springs. Green Swamp is primarily underlain by the Upper Eocene Ocala Limestone with the 
Lower Oligocene Suwannee Limestone under the southwestern part of the province. Miocene Hawthorn Group sediments occur scattered throughout the swamp. Undifferentiated TertiaryQuaternary and reworked Cypresshead Formation siliciclastic sediments cover much of Green Swamp. Within the study area, Green Swamp is underlain by Upper Eocene Ocala Limestone and undifferentiated Quaternary sediments.

\section{Land O’ Lakes Karst Plain}

The Land O’ Lakes Karst Plain province occurs from southwestern Hernando County southward to Pinellas and Hillsborough Counties. It lies west of the southern end of the Brooksville Ridge, west of the Green Swamp and north and west of the northern boundary of the Sarasota River District (OFMS 102; Plate 3, Figure 3). The occurrence of karst features varies from abundant and closely spaced to scattered. Sand dunes are present in several areas of the karst plain. This area varies from poorly drained to well drained and there are many springs. The northern half of the Land O' Lakes Karst Plain, including the present study area, is underlain by the Lower Oligocene

Suwannee Limestone. The Upper Oligocene to Lower Miocene Tampa Member of the Arcadia Formation, Hawthorn Group underlies the southern portion of the karst plain. Clays and sands of Miocene undifferentiated Hawthorn Group overlie the carbonate sediments over much of the area. Quaternary siliciclastic sediments cover much of the karst plain. Elevations in the Land O' Lakes Karst Plain range from sea level to 142 feet (43.3 meters). Elevations in the Land O' Lakes Karst Plain over the study area range from 25 feet (7.6 meters) to 135 feet (41.2 meters).

\section{Ocala Karst Hills}

The Ocala Karst Hills province occurs from north-central Marion County southward to northeastern Sumter County (OFMS 102; Plate 3, Figure 3). Several large springs are present in the Ocala Karst Hills, including the Silver Springs Group, which occurs near the eastern edge of the province along the boundary with the Central Lakes District. The karst in this province is relatively mature. The Upper Eocene Ocala Limestone underlies Quaternary siliciclastic sediments of varying thicknesses, while Middle Miocene Hawthorn Group Coosawhatchie Formation sediments are thin where present, or absent. Within the study area, Quaternary siliciclastic sediments overlie the Upper Eocene Ocala Limestone with some isolated outliers of Middle Miocene Hawthorn Group Coosawhatchie Formation sediments. Elevations in the Ocala Karst Hills range from 16 feet (4.9 meters) to 193 feet (58.8 meters). Elevations in the Ocala Karst Hills over the study area range from 50 feet (15.2 meters) to 144 feet (44.2 meters).

\section{Williston Karst Plain}

The Williston Karst Plain province, located on the eastern flank of the Brooksville Ridge, extends eastward to the Hawthorne Lakes Region, the Fairfield Karst Hills, the Ocala Karst Hills, the Tavares Lakes Region, and the Lakeland-Lake Wales Ridge Complex and is underlain by the Upper Eocene Ocala Limestone (OFMS 102; Plate 3, Figures 1 and 3). The study area is covered with variable thicknesses of undifferentiated Quaternary sediments (Scott et al., in preparation). Scattered wells in the Tsala Apopka Lake region reveal that occasionally the Upper Eocene Ocala Limestone is missing and only the Middle Eocene Avon Park Formation is present. 
The Williston Karst Plain abuts Green Swamp south of the study area (OFMS 102; Plate 3, Figure 3). Elevations of the Williston Karst Plain range from 8 feet (2.4 meters) to 162 feet (49.4 meters). Within the mapped area, elevations of the province range from 12 feet (3.6 meters) to 160 feet (48.8 meters) above MSL. Much of the plain is well drained and a number of springs, including the Rainbow Springs Group, just north of the current study area, occur within this province.

\section{LITHOSTRATIGRAPHIC UNITS}

\section{Tertiary System}

\section{Eocene Series}

\section{Avon Park Formation}

The Middle Eocene Avon Park Formation (Tap), first described by Applin and Applin (1944), is the oldest unit investigated in the present study area. The unit consists of cream to light-brown to tan, poorly- to well-indurated, variably fossiliferous limestone (grainstone to wackestone, with rare mudstone). The limestones are interbedded with tan to brown, very poorly- to well-indurated, very fine to medium crystalline, fossiliferous (molds and casts), vuggy dolostones. Organics are often present. Fossils present in the unit include mollusks, foraminifera (Spirolina sp., Lituonella floridana, Bolivina sp., and Cushmania [Dictyoconus] americana), echinoids, algae and carbonized plant remains.

The Avon Park Formation underlies the mapped area and is rarely within $20 \mathrm{ft}$ of land surface in the Tsala Apoka Lake region. The top of the Avon Park ranges from 23 feet (7 meters) above MSL in W-18801 (OFMS 102; Plate 2, cross-section E-E') to 142 feet (43.3 meters) below MSL in W-18737 (OFMS 102; Plate 2, cross-section D-D'). No wells utilized for cross-sections penetrated the entire thickness of the Avon Park Formation. In a few locations mapped as undifferentiated Quaternary sediments or Upper Eocene Ocala Limestone, it is possible to find wells in which the Avon Park Formation is within 20 feet of the surface in the Tsala Apoka Lake region. The Avon Park Formation forms part of the Floridan aquifer system (Southeastern Geological Society Ad Hoc Committee on Florida Hydrostratigraphic Unit Definition, 1986).

\section{Ocala Limestone}

The Upper Eocene Ocala Limestone (To), first described by Dall and Harris (1892), is a biogenic marine limestone comprised largely of foraminifera, mollusks, echinoids and bryozoans. Where present, the Ocala Limestone sits unconformably on the Avon Park Formation. When the Ocala Limestone is absent, such as in isolated locations near the Withlacoochee River and in the Tsala Apopka Lake vicinity, the Avon Park Formation may be in direct, unconformable contact with the overlying undifferentiated Quaternary sediments or rarely the Lower Oligocene Suwannee Limestone. An example of the latter is Jordan Sink, not far from the Withlacoochee River in the Two Mile Prairie Tract of the Withlacoochee State Forest in the northeastern portion of the USGS Holder 7.5 minute quadrangle. The Ocala Limestone is recrystallized to varying degrees, particularly within the northern and western parts of the study area, making the contact between the two units difficult to discern. Based on lithologic differences, the Ocala Limestone can be informally subdivided into an upper and lower unit 
(Scott, 1991b). This subdivision, while often apparent in cores and quarries, is not readily apparent in cuttings. As a consequence of this, the geologic cross-sections do not break out the upper and lower Ocala Limestone.

The upper unit is typically a white to cream, fine- to coarse grained, poorly- to wellindurated, moderately- to well-sorted, very fossiliferous limestone (wackestone, packstone, and grainstone). Fossils commonly include foraminifera (Lepidocyclina ocalana), bryozoans, mollusks, and a rich diversity of echinoids. The lower unit is typically a white to cream, fine- to medium-grained, poorly- to moderately-indurated, moderately- to well-sorted limestone (grainstone to packstone). Fossils include foraminifera (Amphistegina pinarensis, Nummulites [Camerina] vanderstoki, Nummulites [Operculinoides] ocalana), bryozoans, algae, mollusks, echinoids, and crabs.

The top of the Ocala Limestone ranges from 113 feet (34.4 meters) above MSL in W16001 (OFMS 102; Plate 2, cross-sections B-B' and D-D') to 37 feet (11.3 meters) below MSL in W-12148 (OFMS 102; Plate 2, cross-sections A-A' and D-D'). Approximately 70 percent of the wells utilized for geologic cross-sections penetrate the entire thickness of the Ocala Limestone. In these wells, the thickness of the Ocala Limestone ranges from being absent in W-7961 and W18801 on cross-section E-E' (OFMS 102; Plate 2) to 198 feet (60.4 meters) in W-18737 (OFMS 102; Plate 2, cross-section D-D'). In the Tsala Apoka Lake region, the Ocala Limestone thins, and rare rock outcrops of Avon Park Formation (Jordan Sink mentioned previously) are present. The Ocala Limestone is generally thickest in the southeastern portion of the study area off the nose of the Ocala Platform. The Ocala Limestone forms part of the Floridan aquifer system (Southeastern Geological Society Ad Hoc Committee on Florida Hydrostratigraphic Unit Definition, 1986).

\section{Oligocene Series}

\section{Suwannee Limestone}

The Lower Oligocene Suwannee Limestone (Ts), named by Cooke and Mansfield (1936), consists of dolomitized grainstone and packstone in the present field area. The unit is typically gray, tan, light brown to moderate brown, moderately- to very well-indurated, finely- to coarsely-crystalline, with limited occurrences of fossiliferous beds. Fossils present in the unit include mollusks, foraminifera (Fallotella sp.), corals and echinoids (Rhyncholampas gouldii). In the present field area the Suwannee Limestone is often highly karstified.

The Suwannee Limestone lies unconformably on the Ocala Limestone and rarely on the Avon Park Formation and is unconformably overlain by the undifferentiated Hawthorn Group or undifferentiated Quaternary sediments. Outcrops of Suwannee Limestone are concentrated in the southwestern portion of the study area in the southern Brooksville Ridge, with outliers present in portions of the Brooksville Ridge in the northwestern part of the study area. The top of the Suwannee Limestone ranges from 187 feet (54.3 meters) above MSL in W-16001 (OFMS 102; Plate 2, cross-sections B-B' and D-D') to 47 feet (14.3 meters) above MSL in W-10639 (OFMS 102; Plate 2, cross-section C-C'). The Suwannee Limestone forms part of the Floridan aquifer system (Southeastern Geological Society Ad Hoc Committee on Florida Hydrostratigraphic Unit Definition, 1986). 


\section{FLORIDA GEOLOGICAL SURVEY}

\section{Miocene Series}

Hawthorn Group

Sediments of the Miocene Hawthorn Group are thought to have been deposited over the Ocala Platform throughout the area, but post-Miocene erosion and karstification have removed sediments from the crest of the Ocala Platform, exposing the Eocene carbonates in the central portion of the map area (Cooke, 1945; Espenshade and Spencer, 1963; Scott, 1981b). Fossils in the Hawthorn Group are sparse but may include vertebrate remains, corals, and mollusks. Williams et al. (1977) report that the most commonly found fossils are oysters and coral heads. Within the mapped area, the Hawthorn Group is composed of Miocene undifferentiated Hawthorn Group (Th) sediments, and was observed as weathered outcrop in the southern part of the Brooksville Ridge and variably weathered in cores and cuttings. The Middle Miocene Coosawhatchie Formation of the Hawthorn Group (Thc) is found in a few isolated remnants in the northeastern study area within the Ocala Karst Hills Province.

\section{Undifferentiated Hawthorn Group}

The Miocene undifferentiated Hawthorn Group (Th) sediments are light olive gray and blue gray in unweathered sections and reddish brown to reddish gray in weathered sections. They consist of poorly- to moderately-consolidated, clayey sands to silty clays and relatively pure clays with little to no phosphate due to leaching and transport (Scott, 2001). These sediments are present as outcrops in the southwest quadrant of the study area and in the subsurface of the southern Brooksville Ridge (OFMS 102; Plate 1). They are typically deeply weathered. In the southern Brooksville Ridge, undifferentiated Hawthorn Group sediments are often overlain by more than 20 feet (6.1 meters) of undifferentiated Tertiary and Quaternary sediments and/or Quaternary sediments. Hard-rock phosphate deposits are associated with the undifferentiated Hawthorn Group sediments in several places along the eastern flank of the Brooksville Ridge. These hard-rock phosphate deposits were formed by dissolution of phosphate from the Hawthorn Group and subsequent precipitation in karst features within the Ocala Limestone (Scott, 2001).

Where present, undifferentiated Hawthorn Group sediments unconformably overlie the

Ocala Limestone or the Suwannee Limestone (Scott, 1988). They are at times unconformably overlain by undifferentiated Quaternary sediments or undifferentiated Tertiary/Quaternary sediments. Thin beds of the undifferentiated Hawthorn Group were penetrated in a few wells in the northwestern portion of the map area. In these, the top of the Hawthorn Group ranges from 41 feet (12.5 meters) above MSL in W-11452 (OFMS 102; Plate 2, cross-section D-D') to 27 feet (9.8 meters) below MSL in W-12148 (OFMS 102; Plate 2, cross-sections A-A' and D-D'). The undifferentiated Hawthorn Group is only 10-25 feet (3.1-7.6 meters) thick in each of these wells. Undifferentiated Hawthorn Group sediments also mantle hilltops in the southwestern part of the study area. The maximum elevation observed was 209 feet (63.7 meters) above MSL in W16001 (OFMS 102; Plate 2, cross-sections B-B' and D-D'). Undifferentiated Hawthorn Group sediments are often clayey sands with some permeability, and only rarely consist of relatively pure clays. The undifferentiated Hawthorn Group sediments generally have low permeability and form part of the intermediate aquifer system/intermediate confining unit (Southeastern Geological Society Ad Hoc Committee on Florida Hydrostratigraphic Unit Definition, 1986). 
Coosawhatchie Formation

The Middle Miocene Coosawhatchie Formation (Thc) is exposed or lies beneath a thin overburden on the eastern flank of the Ocala Platform in the present study area. It typically ranges from a light gray to olive gray, poorly-consolidated, variably clayey sand with minor dolostone, to an olive gray, poorly- to moderately-consolidated, slightly sandy, silty clay. The unit may contain 20 percent or more phosphate but generally has less than 10 percent phosphate (Scott, 1988). The Coosawhatchie Formation lies unconformably on the Ocala Limestone and is unconformably overlain by undifferentiated Quaternary sediments (Qu). The top of the Coosawhatchie Formation ranges from 78 feet (23.8 meters) above MSL in W-1707 (OFMS 102; Plate 2, cross-sections A-A' and F-F') to 76 feet (23.2 meters) above MSL in W-334 (OFMS 102; Plate 2, cross-section F-F') to and occurs in the northeastern portion of the study area. The Coosawhatchie Formation is between 18-30 feet (5.5-9.1 meters) thick based upon information from the previously mentioned wells. Permeability of the Coosawhatchie sediments is generally low, forming part of the intermediate confining unit/aquifer system (Southeastern Geological Society Ad Hoc Committee on Florida Hydrostratigraphic Unit Definition, 1986).

\title{
Tertiary/Quaternary Systems
}

\section{Pliocene Series}

\author{
Undifferentiated Tertiary/Quaternary Sediments
}

Undifferentiated Tertiary/Quaternary sediments (TQu) are siliciclastics that are separated from the lithologically similar undifferentiated Quaternary sediments solely on the basis of elevation (Scott et al., 2001). Pleistocene sea levels reached a maximum of approximately 100 feet (30.5 meters) above MSL (Colquhoun, 1969). The sediments which occur above 100 feet (30.5 meters) MSL are predominately older than Pleistocene but may have been reworked during the Pleistocene. They are present in the northwestern portion of the map area (OFMS 102; Plate 1) in areas where elevations exceed 100 feet (30.5 meters). Some areas below 100 feet (30.5 meters) may be included in the undifferentiated Tertiary/Quaternary sediments where not including them would have created very complex map polygons. These poorly-consolidated to unconsolidated siliciclastics are white to gray to orange to blue-green, fine- to coarse-grained, clean to clayey unfossiliferous sands, sandy clays and clays with variable admixtures of clay and organics. Permeable sediments of the undifferentiated Tertiary/Quaternary sediments form part of the surficial aquifer system (Southeastern Geological Society Ad Hoc Committee on Florida Hydrostratigraphic Unit Definition, 1986).

\section{Pleistocene to Holocene Series}

\section{Undifferentiated Quaternary Sediments}

Undifferentiated Quaternary sediments $(\mathrm{Qu})$ lie unconformably on the Avon Park Formation, the Ocala Limestone, the Suwannee Limestone, undifferentiated Hawthorn Group, or on Coosawhatchie Formation sediments. The Avon Park Formation and the undifferentiated Quaternary sediments are only in direct contact in some instances where the Ocala Limestone is absent from the section. 
The undifferentiated Quaternary sediments present in the western and eastern portions of the mapped area are highly variable in thickness. Data from this project indicate that the surface of the Ocala Limestone in these areas is heavily karstified. Overlying sediments may range from 20 feet (6.1 meters) to over 130 feet (39.6 meters) thick on the Brooksville Ridge. Relief on the surface of the Ocala Limestone regularly exceeds 30 feet (9.1 meters) in karstic areas. Much of these undifferentiated sediments are derived from erosion and weathering of Hawthorn Group and younger units such as the Cypresshead Formation, and sinkholes may contain Hawthorn Group sediments (Scott, 1992). Field evidence also shows that small pinnacles of Ocala Limestone or Suwannee Limestone and outliers of weathered Hawthorn Group sediments can occur in these areas.

Generally, these undifferentiated Quaternary sediments consist of white to gray to orange to blue-green, fine- to coarse-grained, clean to clayey unfossiliferous sands, sandy clays and clays with variable admixtures of organics. They are only separated from the undifferentiated Tertiary/Quaternary sediments due to current elevations below 100 feet (30.5 meters). The undifferentiated Quaternary sediments form part of the surficial aquifer system (Southeastern Geological Society Ad Hoc Committee on Florida Hydrostratigraphic Unit Definition, 1986). Where these sediments lack clays and overlie the Eocene or Oligocene limestones, they are hydraulically connected to the Floridan aquifer system.

Quaternary Beach Ridge and Dune

The sediments of the beach ridge and dune (Qbd) are a subdivision of the undifferentiated Quaternary sediments that are noted on the basis of surficial expression of beach ridges and dunes. These sediments typically unconformably overlie the Ocala Limestone or the Suwannee Limestone. Beach ridge and dune sediments occur in three generalized areas in the study area. The most continuous region is in the southwestern part of the study area along the western flank of the southern Brooksville Ridge. Another location is along the southeastern flank of the Brooksville Ridge. Many of these dunes were single parabolic dunes or remnants too small to individually map, but a few larger sets are mapped (OFMS 102; Plate 1). The last area occurs in the eastern portion of the study area, within the Williston Karst Plain, and are the largest fields averaging $3.4 \mathrm{~km}^{2}$. These dunes form along the highlands of undifferentiated Quaternary Sediments which lie to the east of the lowlands of the Tsala Apopka Lake and Withlacoochee River valley both north-northwest and south-southeast of Lake Panasoffkee. Subdivisions of the undifferentiated Quaternary sediments are not formally recognized lithostratigraphic units, but are noted to facilitate a better understanding of Florida's Quaternary geology (Scott, 2001).

Beach ridge and dune sediments are dominantly siliciclastic sands and are unconsolidated to poorly consolidated. Organics typically occur as disseminated organic matrix, roots and plant debris, carbonized remains or charcoal. These sediments are considered part of the surficial aquifer system (Southeastern Geological Society Ad Hoc Committee on Florida Hydrostratigraphic Unit Definition, 1986).

\section{HYDROGEOLOGY}

Hydrostratigraphic units within the map area, in ascending order, consist of the Floridan aquifer system (FAS), the intermediate aquifer system/intermediate confining unit (IAS/ICU), and the surficial aquifer system (SAS) (Southeastern Geological Society Ad Hoc Committee on 
Florida Hydrostratigraphic Unit Definition, 1986). The FAS, the primary source for springs and drinking water in the region, is generally comprised of carbonate units of the Avon Park Formation, the Ocala Limestone, and the Suwannee Limestone. The sands, silts, clays and carbonates of the Hawthorn Group comprise the IAS/ICU. The IAS/ICU is highly localized and laterally discontinuous in the study area. The SAS is comprised of the undifferentiated Tertiary/Quaternary sediments (TQu), the undifferentiated Quaternary sediments (Qu) and the Beach Ridge and Dune sediments (Qbd).

Where clayey siliciclastic sediments of the Hawthorn Group and younger units are thick and continuous, they provide confinement for the FAS, but where the clayey siliciclastic sediments of the Hawthorn Group and younger units are thin, missing or lack significant clay component, karst features often occur. Swallets (stream-to-sink features) are of particular concern to geoscientists and hydrogeologists. Several of these are found in the southern Brookville Ridge, particularly where areas of undifferentiated Hawthorn Group sediments thinly cover the Suwannee Limestone (OFMS 102; Plate 3, Figure 1).

\section{DERIVATIVE PRODUCTS}

Several derivative products will come from this project. During the mapping project, data from over 500 wells were analyzed (Appendix A includes those within the study area boundary and top of limestone rock information from Water Management District wells). Formation picks, made on all available wells with cores and cuttings samples, allow creation of a structure contour map of the top of the Floridan aquifer system, along with the construction of structure contour and isopach maps of the IAS/ICU in the area. Additional derivative data anticipated to come from this mapping effort include aquifer vulnerability assessment maps. Data derived from prior STATEMAP products have often been used to augment other Florida Geological Survey and Florida Aquifer Vulnerability Assessment (FAVA) projects in the state (Arthur et al., 2007; Baker et al., 2007). 


\section{FLORIDA GEOLOGICAL SURVEY}

\section{REFERENCES}

Adams, P.N., Opdyke, N.D., and Jaeger, J.M., 2010, Isostatic uplift driven by karstification and sea-level oscillation: Modeling landscape evolution in North Florida: Geology, v. 38, p. 531534.

Allison, D., Groszos, M., and Rupert, F., 1995, Top of rock of the Floridan aquifer system in the Suwannee River Water Management District: Florida Geological Survey Open-File Map Series 84, scale 1:475,000.

Alt, D., and Brooks, H.K., 1965, Age of the Florida marine terraces: Journal of Geology, v. 73, p. 406-411.

Applin, P., 1951, Possible future petroleum provinces of North America - Florida: American Association of Petroleum Geologists Bulletin, v. 35, p. 405-407.

Applin, P.L., and Applin, E.R., 1944, Regional subsurface stratigraphy and structure of Florida and southern Georgia: American Association of Petroleum Geologists Bulletin, v. 28, p. 1673-1753.

Arthur, J.D., Wood, H.A.R., Baker, A.E., Cichon, J.R., and Raines, G.L., 2007, Development and implementation of a Bayesian-based aquifer vulnerability assessment in Florida: Natural Resources Research, v. 16, p. 93-107.

Arthur, J.D., Fischler, C., Kromhout, C., Clayton, J.M., Kelley, G.M., Lee, R.A., Li, L., O’Sullivan, M., Green, R.C., and Werner, C.L., 2008, Hydrogeologic framework of the Southwest Florida Water Management District: Florida Geological Survey Bulletin 68, 102 p., 59 plates.

Baker, A.E., Wood, H.A.R., and Cichon, J.R., 2007, The Marion County Aquifer Vulnerability Assessment: unpublished report submitted to Marion County Board of County Commissioners in fulfillment of Marion County Project No. SS06-01, March 2007, 42 p.

Bryan, J.R., 2004, Larger foraminifera: Introduction, biology, ecology, taxonomic and stratigraphic listings and comments on Florida fossil assemblages: Florida Paleontological Society, Florida Fossil Invertebrates, Part 6, 28 p.

Bush, P.W., and Johnston, R.A., 1988, Ground-water hydraulics, regional flow, and groundwater development of the Floridan aquifer system in Florida and in parts of Georgia, South Carolina, and Alabama: U.S. Geological Survey Professional Paper 1403-C, 80 p.

Campbell, K.M., 1993a, Geologic map of Sumter County, Florida: Florida Geological Survey Open-File Map Series 35, Scale 1:126,720.

1993b, Geologic map of Hernando County, Florida: Florida Geological Survey Open-File Map Series 35, Scale 1:126,720. 
Campbell, K.M., and Scott, T.M., 1992, Geologic Map of Citrus County, Florida: Florida Geological Survey Open-File Map Series 10, Scale 1:126,720.

Colquhoun, D.J., 1969, Coastal plain terraces in the Carolinas and Georgia, U.S.A., in Wright, H.E., Jr., ed., Quaternary Geology and Climate: Volume 16 of the Proceedings of the VII Congress of the International Association for Quaternary Research, p. 150-162.

Colquhoun, D.J., Johnson, G.H., Peebles, P.C., Huddlestun, P.F., and Scott, T., 1991, Quaternary geology of the Atlantic Coastal Plain, in Morrison, R.B., ed., Quaternary nonglacial geology; Conterminous U.S.: Boulder, Colorado, Geological Society of America, The Geology of North America, v. K-2, p. 629-650.

Cooke, C.W., 1931, Seven coastal terraces in the southeastern United States: Washington Academy of Sciences Journal, v. 21, p. 503-513.

Cooke, C.W., and Mansfield, W.C., 1936, Suwannee limestone of Florida (abstract): Geological Society of America Proceedings 1935, p. 71-72.

Cooke, C.W., 1939, Scenery of Florida interpreted by a geologist: Florida Geological Survey Bulletin 17, 120 p. , 1945, Geology of Florida: Florida Geological Survey Bulletin 29, 342 p.

Copeland, R., 2003, Florida spring classification system and spring glossary: Florida Geological Survey Special Publication 52, 17 p.

Copeland, R., Doran, N.A., White, A.J., and Upchurch, S.B., 2009, Regional and statewide trends in Florida's spring and well groundwater quality (1991-2003): Florida Geological Survey Bulletin 69, 203 p.

Dall, W.H., and Harris, G.D., 1892, Correlation papers, Neocene: United States Geological Survey Bulletin 84, 349 p.

Espenshade, G.H., and Spencer, C.W., 1963, Geologic features of phosphate deposits of northern peninsular Florida: United States Geological Survey Bulletin 1118, 115 p.

Evans, W.L., III, Green, R.C., Bryan, J.R., and Paul, D.T., 2004, Geologic map of the western portion of the USGS 1:100,000 scale Gainesville quadrangle, northern Florida: Florida Geological Survey Open-File Map Series 93, scale 1:100,000, 2 plates.

Flint, R.F., 1940, Pleistocene features of the Atlantic coastal plain: American Journal of Science, v. 238, p. 757-787. 1971, Glacial and Quaternary Geology: New York, John Wiley and Sons, Inc., 892 p. 


\section{FLORIDA GEOLOGICAL SURVEY}

Green, R.C., Evans, W.L., III, Paul, D.T., and Scott, T.M., 2005, Geologic map of the eastern portion of the USGS 1:100,000 scale Gainesville quadrangle, northern Florida: Florida Geological Survey Open-File Map Series 94, scale 1:100,000, 2 plates.

Green, R.C., Williams, C.P., Paul, D.T., Kromhout, C., and Scott, T.M., 2009a, Geologic map of the eastern portion of the USGS Ocala 30 x 60 minute quadrangle, north-central Florida: Florida Geological Survey Open-File Map Series 100, scale 1:100,000, 3 plates.

Green, R.C., Williams, C.P., Paul, D.T., Kromhout, C., and Scott, T.M., 2009b, Text to accompany geologic map of the eastern portion of the USGS Ocala $30 \times 60$ minute quadrangle, north-central Florida: Florida Geological Survey Open-File Report 93, 29 p.

Green, R.C., Williams, C.P., Flor, A.D., Paul, D.T., Kromhout, C., and Scott, T.M., 2010, Geologic map of the western portion of the USGS Ocala 30 x 60 minute quadrangle, northcentral Florida, Florida Geological Survey Open-File Map Series 101, scale 1:100,000, 3 plates.

Groszos, M., and Rupert, F.R., 1992, An isopach map of the Hawthorn Group in the Suwannee River Water Management District: Florida Geological Survey Open-File Map Series 2, scale 1:250, 000 .

Healy, H.G., 1975, Terraces and shorelines of Florida: Florida Geological Survey Map Series 71, scale: 1:2,095,200.

Hopkins, O.B., 1920, Drilling for oil in Florida: United States Geological Survey Press Bulletin, April, 1920.

Jones, G.W., Upchurch, S.B., and Champion, K.M., 1996, Origin of nitrate in groundwater discharging from Rainbow Springs, Marion County, Florida: Southwest Florida Water Management District Report, 155 p.

MacNeil, F.S., 1950, Pleistocene shorelines in Florida and Georgia: U.S. Geological Survey Professional Paper 221-F, p. 95-107.

Matson, G.C., and Sanford, S., 1913, Geology and groundwater of Florida: U.S. Geological Survey Water Supply Paper 319, 445 p.

McBride, W.S., Bellino, J.C., and Swancar, A., 2011, Hydrology, water budget, and water chemistry of Lake Panasoffkee, west-central Florida: U.S. Geological Survey Scientific Investigations Report 2010-5237, 96 p.

Miller, J.A., 1986, Hydrogeologic framework of the Florida aquifer system in Florida and in parts of Georgia, Alabama, and South Carolina: Regional Aquifer-System Analysis: U.S. Geological Survey Professional Paper 1403-B, 91 p., 33 plates. 
Opdyke, N.D., Spangler, D.P., Smith, D.L., Jones, R.C., and Lindquist, R.C., 1984, Origin of the epeirogenic uplift of Pliocene-Pleistocene beach ridges in Florida and development of the Florida karst: Geology, v. 12, p. 226-228.

Phelps, G.G., 1994, Hydrogeology, water quality and potential for contamination of the Upper Floridan Aquifer in the Silver Springs Ground-Water Basin, Central Marion County, Florida: U.S. Geological Survey Water-Resources Investigations Report 92-4159, 69 p.

, 2004, Chemistry of groundwater in the Silver Springs Basin, with an emphasis on Nitrate: U.S. Geological Survey Scientific Investigations Report 2004-5144, 54 p.

Pirkle, E.C., Jr., Yoho, W.H., and Hendry, C.W., Jr., 1970, Ancient sea level stands in Florida: Florida Geological Survey Bulletin 52, 61 p.

Puri, H.S., 1957, Stratigraphy and zonation of the Ocala Group: Florida Geological Survey Bulletin 38, 248 p.

Puri, H.S., and Vernon, R.O., 1964, Summary of the geology of Florida and a guidebook to the classic exposures: Florida Geological Survey Special Publication 5, revised, 312 p.

Schmidt, W., 1984, Neogene stratigraphy and geologic history of the Apalachicola Embayment: Florida Geological Survey Bulletin 58, 146 p.

Scott, T.M., 1981a, The paleo-extent of the Miocene Hawthorn Formation in peninsular Florida [abstract]: Florida Scientist, v. 44, Supplement 1, p. 42.

, 1981b, The Hawthorn Formation of North Florida: Southeastern Geological Society, Field Conference Guidebook, v. 23, p. 15-23.

, 1988, The lithostratigraphy of the Hawthorn Group (Miocene) of Florida: Florida Geological Survey Bulletin 59, 148 p.

, 1991a, Depositional patterns of the Hawthorn Group in Florida: Geological Society of America Abstracts with Programs, v. 23, no. 1, p. 126.

, 1991b, A geological overview, in Scott, T.M., Lloyd, J.M., and Maddox, G.L., eds., Florida's ground-water quality monitoring program, hydrogeologic framework: Florida Geological Survey Special Publication 32, 97 p.

1992, Geologic map of Marion County, Florida: Florida Geological Survey OpenFile Map Series 13, scale 1:126,720.

, 1997, Miocene to Holocene history of Florida, in Randazzo, A.F. and Jones, D.S., eds., The geology of Florida: Gainesville, University Press of Florida, 327 p. 


\section{FLORIDA GEOLOGICAL SURVEY}

, 2001, Text to accompany the geologic map of Florida: Florida Geological Survey Open-File Report 80, 29 p.

, 2005, Revisions to the geomorphology of Florida focusing on the eastern panhandle and north-central Florida, in Southeastern Geological Society Field Trip Guidebook 44, p. 18-36.

Scott, T.M., Campbell, K.M., Rupert, F.R., Arthur, J.A., Green, R.C., Means, G.H., Missimer, T.M., Lloyd, J.M., and Duncan, J.G., 2001, Geologic map of Florida: Florida Geological Survey Map Series 146, scale 1:750,000.

Scott, T.M., Means, G.H., Means, R.C., and Meegan R.P., 2002, First magnitude springs of Florida: Florida Geological Survey Open-File Report 85, 138 p.

Scott, T.M., Means, G.H., Meegan, R.P., Means, R.C., Upchurch, S.B., Copeland, R.E., Jones, J., Roberts, T., and Willet, A., 2004, Springs of Florida: Florida Geological Survey Bulletin 66, 377 p.

Scott, T.M., Paul, D.T., Means, G.H., and Williams, C.P. (in preparation) Geomorphic map of Florida: Florida Geological Survey, scale 1:750,000.

Sinclair, W.C., and Stewart, J.W., 1985, Sinkhole type, development, and distribution in Florida: Florida Geological Survey Map Series 110, scale 30 miles to 1 inch.

Southeastern Geological Society Ad Hoc Committee on Florida Hydrostratigraphic Unit Definition, 1986, Hydrogeological units of Florida: Florida Geological Survey Special Publication 28, 8 p.

Upchurch, S.B., Champion, K.M., Schnieder, J.C., Hornsby, D., Ceryak, R., and Zwanka, W., 2004, Defining springshed boundaries and water-quality domains near first-magnitude springs in north Florida [abstract]: Florida Scientist, v. 67, Supplement 1, 52 p.

U.S. Geological Survey, 1978, 1:100,000-scale metric topographic map of Ocala, Florida: Reston, U.S. Geological Survey, 1 sheet.

Vernon, R.O., 1951, Geology of Citrus and Levy Counties, Florida: Florida Geological Survey Bulletin 33, 256 p.

White, W.A., 1970, The geomorphology of the Florida peninsula: Florida Geological Survey Bulletin 51, 164 p.

Williams, C.P., Green, R.C., Flor, A.D., Paul, D.T., Scott, T.M., and Kromhout, C., 2010, Text to accompany geologic map of the western portion of the USGS Ocala $30 \times 60$ minute quadrangle, north-central Florida, Florida Geological Survey Open-File Report 94, 29 p. 
Williams, K.E., Nicol, D., and Randazzo, A.F., 1977, The geology of the western part of Alachua County, Florida: Florida Geological Survey Report of Investigation 85, 97 p.

\section{ACKNOWLEDGEMENTS}

The authors extend many thanks to the personnel that assisted with access to land holdings: Colleen Werner and Wilbur Priest at the Withlacoochee State Forest who provided much assistance with road access and facilitating coring on their land, and Dave Dewitt from the Southwest Florida Water Management District.

Ken Campbell, David Paul, Jesse Hurd, Eric Thomas and Guy Richardson provided field support for drilling operations. Amber Raynsford and Lisa Fulton worked to make sure all wells were appropriately located using every piece of archived well location information that could be found. Thank you to Frank Rupert, Jackie Lloyd, Clint Kromhout, and Harley Means who reviewed, discussed and edited the product. Tom Scott continues to be an asset to geologic mapping in Florida and the ongoing work to revise the state's geomorphic map. This geologic map was funded in part by the Office of the Florida Geological Survey of the Florida Department of Environmental Protection and by the United States Geological Survey National Cooperative Geologic Mapping Program under assistance award number G10AC00426 in Federal fiscal year 2010. 
FLORIDA GEOLOGICAL SURVEY

\section{APPENDIX A: WELLS UTILIZED FOR STUDY}

\begin{tabular}{|c|c|c|c|c|c|c|c|c|}
\hline $\begin{array}{l}\text { Map } \\
\text { ID }\end{array}$ & Well Label & Data Source & Sample Type & Longitude & Latitude & 24K Quad & $\begin{array}{c}\text { Elevation } \\
(\mathrm{ft})\end{array}$ & $\begin{array}{c}\text { Total } \\
\text { Depth }(\mathrm{ft})\end{array}$ \\
\hline 1 & W-251 & FGS & Cuttings & -82.036503 & 28.911588 & OXFORD & 78 & 85 \\
\hline 2 & W-334 & FGS & Cuttings & -82.031389 & 28.928611 & OXFORD & 101 & 80 \\
\hline 3 & W-808 & FGS & Cuttings & -82.074519 & 28.689534 & BUSHNELL & 80 & 385 \\
\hline 4 & W-1707 & FGS & Cuttings & -82.041750 & 28.982555 & OXFORD & 88 & 165 \\
\hline 5 & W-2876 & FGS & Cuttings & -82.440744 & 28.596869 & BROOKSVILLE & 123 & 1154 \\
\hline 6 & W-6540 & FGS & Cuttings & -82.205636 & 28.619599 & SAINT CATHERINE & 42 & 420 \\
\hline 7 & W-6590 & FGS & Cuttings & -82.067546 & 28.804084 & WILDWOOD & 71 & 150 \\
\hline 8 & W-7755 & FGS & Cuttings & -82.451546 & 28.727385 & BROOKSVILLE NW & 33 & 171 \\
\hline 9 & W-7833 & FGS & Cuttings & -82.217145 & 28.551133 & SAINT CATHERINE & 53 & 294 \\
\hline 10 & W-7961 & FGS & Cuttings & -82.274685 & 28.849512 & INVERNESS & 47 & 40 \\
\hline 11 & W-8382 & FGS & Cuttings & -82.212896 & 28.587640 & SAINT CATHERINE & 56 & 135 \\
\hline 12 & W-8418 & FGS & Cuttings & -82.122037 & 28.983606 & LAKE PANASOFFKEE NW & 73 & 66 \\
\hline 13 & W-10376 & FGS & Cuttings & -82.328130 & 28.746052 & NOBLETON & 95 & 125 \\
\hline 14 & W-10554 & FGS & Cuttings & -82.298359 & 28.743866 & NOBLETON & 91 & 200 \\
\hline 15 & W-10639 & FGS & Cuttings & -82.344525 & 28.569087 & BROOKSVILLE SE & 87 & 416 \\
\hline 16 & W-10680 & FGS & Cuttings & -82.394628 & 28.865368 & LECANTO & 60 & 143 \\
\hline 17 & W-10720 & FGS & Cuttings & -82.178782 & 28.588554 & SAINT CATHERINE & 70 & 225 \\
\hline 18 & W-10855 & FGS & Cuttings & -82.293074 & 28.571484 & BROOKSVILLE SE & 99 & 250 \\
\hline 19 & W-10901 & FGS & Cuttings & -82.061706 & 28.600266 & WEBSTER & 90 & 66 \\
\hline 20 & W-11452 & FGS & Cuttings & -82.371655 & 28.897282 & HOLDER & 67 & 73 \\
\hline 21 & W-11606 & FGS & Cuttings & -82.045715 & 28.835873 & WILDWOOD & 60 & 400 \\
\hline 22 & W-11788 & FGS & Cuttings & -82.079129 & 28.777666 & WILDWOOD & 55 & 80 \\
\hline 23 & W-11817 & FGS & Cuttings & -82.162514 & 28.588340 & SAINT CATHERINE & 63 & 160 \\
\hline 24 & W-12148 & FGS & Cuttings & -82.431580 & 28.963309 & HOLDER & 78 & 178 \\
\hline 25 & W-12879 & FGS & Cuttings & -82.045588 & 28.865104 & WILDWOOD & 58 & 300 \\
\hline 26 & W-13349 & FGS & Cuttings & -82.068798 & 28.735642 & BUSHNELL & 80 & 180 \\
\hline 27 & W-13716 & FGS & Cuttings & -82.360967 & 28.953119 & STOKES FERRY & 40 & 158 \\
\hline 28 & W-14629 & FGS & Cuttings & -82.180750 & 28.977556 & LAKE PANASOFFKEE NW & 74 & 221 \\
\hline 29 & W-15942 & FGS & Core & -82.214191 & 28.603931 & SAINT CATHERINE & 64 & 300 \\
\hline 30 & W-16001 & FGS & Core & -82.414503 & 28.728205 & BROOKSVILLE NW & 219 & 162 \\
\hline 31 & W-16022 & FGS & Core & -82.064448 & 28.771891 & WILDWOOD & 57 & 204.5 \\
\hline 32 & W-16311 & FGS & Core & -82.127374 & 28.774567 & RUTLAND & 52 & 270 \\
\hline 33 & W-16611 & FGS & Core & -82.219722 & 28.753611 & RUTLAND & 51 & 566 \\
\hline 34 & W-17469 & FGS & Core & -82.404322 & 28.556189 & BROOKSVILLE & 99 & 95 \\
\hline 35 & W-18681 & FGS & Core & -82.337056 & 28.955556 & STOKES FERRY & 42 & 26 \\
\hline 36 & W-18737 & FGS & Core & -82.403800 & 28.685367 & BROOKSVILLE NW & 91 & 242.6 \\
\hline 37 & W-18801 & FGS & Core & -82.256750 & 28.821083 & INVERNESS & 43 & 41 \\
\hline 38 & W-19261 & FGS & Core & -82.305944 & 28.904638 & STOKES FERRY & 44 & 93.6 \\
\hline 39 & W-19291 & FGS & Core & -82.407833 & 28.768000 & LECANTO & 118 & 254.25 \\
\hline 40 & W-19292 & FGS & Core & -82.044588 & 28.521919 & WEBSTER & 88 & 250 \\
\hline 41 & W-3 & FGS & Cuttings & -82.063056 & 28.645833 & BUSHNELL & 76 & 3090 \\
\hline 42 & W-274 & FGS & Cuttings & -82.366846 & 28.616211 & BROOKSVILLE SE & 261 & 804 \\
\hline 43 & W-807 & FGS & Cuttings & -82.073956 & 28.690208 & BUSHNELL & 79 & 370 \\
\hline 44 & W-874 & FGS & Cuttings & -82.302265 & 28.748924 & NOBLETON & 63 & 200 \\
\hline 45 & W-1442 & FGS & Cuttings & -82.254496 & 28.506684 & BROOKSVILLE SE & 160 & 270 \\
\hline 46 & W-1712 & FGS & Cuttings & -82.018597 & 28.987167 & OXFORD & 79 & 111 \\
\hline 47 & W-1721 & FGS & Cuttings & -82.055340 & 28.656896 & BUSHNELL & 89 & 347 \\
\hline 48 & W-1735 & FGS & Cuttings & -82.024087 & 28.871130 & WILDWOOD & 84 & 160 \\
\hline 49 & W-1762 & FGS & Cuttings & -82.018597 & 28.987167 & OXFORD & 80 & 141 \\
\hline 50 & W-1767 & FGS & Cuttings & -82.499742 & 28.947152 & HOLDER & 113 & 233 \\
\hline 51 & W-1790 & FGS & Cuttings & -82.433732 & 28.669967 & BROOKSVILLE NW & 160 & 325 \\
\hline 52 & W-2645 & FGS & Cuttings & -82.046597 & 28.860573 & WILDWOOD & 62 & 145 \\
\hline 53 & W-2688 & FGS & Cuttings & -82.046590 & 28.859739 & WILDWOOD & 65 & 105 \\
\hline 54 & W-3675 & FGS & Cuttings & -82.177045 & 28.509406 & SAINT CATHERINE & 65 & 820 \\
\hline 55 & W-3711 & FGS & Cuttings & -82.296447 & 28.752085 & INVERNESS & 70 & 212 \\
\hline 56 & W-4114 & FGS & Cuttings & -82.390165 & 28.550695 & BROOKSVILLE & 142 & 656 \\
\hline 57 & W-4410 & FGS & Cuttings & -82.176380 & 28.512203 & SAINT CATHERINE & 183 & 1300 \\
\hline 58 & W-4697 & FGS & Cuttings & -82.377003 & 28.579547 & BROOKSVILLE & 101 & 337 \\
\hline
\end{tabular}


OPEN-FILE REPORT 96

\begin{tabular}{|c|c|c|c|c|c|c|c|c|}
\hline $\begin{array}{l}\text { Map } \\
\text { ID }\end{array}$ & Well Label & Data Source & Sample Type & Longitude & Latitude & 24K Quad & $\begin{array}{c}\text { Elevation } \\
(\mathrm{ft})\end{array}$ & $\begin{array}{c}\text { Total } \\
\text { Depth }(\mathrm{ft})\end{array}$ \\
\hline 59 & W-4830 & FGS & Cuttings & -82.386040 & 28.547118 & BROOKSVILLE & 143 & 620 \\
\hline 60 & W-4879 & FGS & Cuttings & -82.029265 & 28.866805 & WILDWOOD & 83 & 105 \\
\hline 61 & W-5608 & FGS & Cuttings & -82.394115 & 28.532869 & BROOKSVILLE & 143 & 207 \\
\hline 62 & W-5694 & FGS & Cuttings & -82.300261 & 28.519708 & BROOKSVILLE SE & 117 & 200 \\
\hline 63 & W-5759 & FGS & Cuttings & -82.201427 & 28.572258 & SAINT CATHERINE & 56 & 72 \\
\hline 64 & W-6234 & FGS & Cuttings & -82.490902 & 28.663316 & BROOKSVILLE NW & 121 & 667 \\
\hline 65 & W-6392 & FGS & Cuttings & -82.110700 & 28.666350 & BUSHNELL & 77 & 80 \\
\hline 66 & W-6393 & FGS & Cuttings & -82.110700 & 28.666350 & BUSHNELL & 76 & 90 \\
\hline 67 & W-6394 & FGS & Cuttings & -82.110700 & 28.666350 & BUSHNELL & 76 & 90 \\
\hline 68 & W-6475 & FGS & Cuttings & -82.113334 & 28.761938 & WILDWOOD & 53 & 210 \\
\hline 69 & W-6541 & FGS & Cuttings & -82.205636 & 28.619599 & SAINT CATHERINE & 42 & 414 \\
\hline 70 & W-6551 & FGS & Cuttings & -82.113334 & 28.761938 & WILDWOOD & 47 & 57 \\
\hline 71 & W-6562 & FGS & Cuttings & -82.406399 & 28.532592 & BROOKSVILLE & 101 & 420 \\
\hline 72 & W-6670 & FGS & Cuttings & -82.427169 & 28.957643 & HOLDER & 45 & 1116 \\
\hline 73 & W-7311 & FGS & Cuttings & -82.047693 & 28.848728 & WILDWOOD & 61 & 65 \\
\hline 74 & W-7602 & FGS & Cuttings & -82.377699 & 28.923861 & HOLDER & 67 & 65 \\
\hline 75 & W-7728 & FGS & Cuttings & -82.426085 & 28.551176 & BROOKSVILLE & 79 & 180 \\
\hline 76 & W-7736 & FGS & Cuttings & -82.209730 & 28.568552 & SAINT CATHERINE & 66 & 85 \\
\hline 77 & W-7737 & FGS & Cuttings & -82.222172 & 28.583163 & SAINT CATHERINE & 55 & 65 \\
\hline 78 & W-7750 & FGS & Cuttings & -82.354005 & 28.829406 & INVERNESS & 77 & 80 \\
\hline 79 & W-7756 & FGS & Cuttings & -82.450711 & 28.726419 & BROOKSVILLE NW & 50 & 41.5 \\
\hline 80 & W-7757 & FGS & Cuttings & -82.450014 & 28.777756 & LECANTO & 72 & 64 \\
\hline 81 & W-7759 & FGS & Cuttings & -82.478333 & 28.903611 & HOLDER & 68 & 335 \\
\hline 82 & W-7782 & FGS & Cuttings & -82.139539 & 28.670120 & WAHOO & 63 & 80 \\
\hline 83 & W-7882 & FGS & Cuttings & -82.103335 & 28.754730 & WILDWOOD & 55 & 60 \\
\hline 84 & W-7893 & FGS & Cuttings & -82.359977 & 28.540767 & BROOKSVILLE SE & 89 & 446 \\
\hline 85 & W-7906 & FGS & Cuttings & -82.327534 & 28.996482 & STOKES FERRY & 52 & 45 \\
\hline 86 & W-7911 & FGS & Cuttings & -82.078760 & 28.865040 & WILDWOOD & 54 & 37 \\
\hline 87 & W-7960 & FGS & Cuttings & -82.333623 & 28.832957 & INVERNESS & 76 & 48 \\
\hline 88 & W-7962 & FGS & Cuttings & -82.230520 & 28.848657 & RUTLAND & 42 & 31 \\
\hline 89 & W-7963 & FGS & Cuttings & -82.212488 & 28.853111 & RUTLAND & 50 & 22 \\
\hline 90 & W-7964 & FGS & Cuttings & -82.189771 & 28.856972 & RUTLAND & 46 & 31 \\
\hline 91 & W-7970 & FGS & Cuttings & -82.122814 & 28.776126 & WILDWOOD & 51 & 203 \\
\hline 92 & W-8010 & FGS & Cuttings & -82.129281 & 28.675544 & WAHOO & 65 & 80 \\
\hline 93 & W-8021 & FGS & Cuttings & -82.315378 & 28.524444 & BROOKSVILLE SE & 75 & 170 \\
\hline 94 & W-8038 & FGS & Cuttings & -82.344043 & 28.702415 & NOBLETON & 80 & 360 \\
\hline 95 & W-8075 & FGS & Cuttings & -82.043611 & 28.987222 & OXFORD & 85 & 285 \\
\hline 96 & W-8188 & FGS & Cuttings & -82.230607 & 28.528353 & SAINT CATHERINE & 74 & 6209 \\
\hline 97 & W-8211 & FGS & Cuttings & -82.390126 & 28.568704 & BROOKSVILLE & 160 & 524 \\
\hline 98 & W-8222 & FGS & Cuttings & -82.043486 & 28.856010 & WILDWOOD & 61 & 125 \\
\hline 99 & W-8255 & FGS & Cuttings & -82.047769 & 28.837731 & WILDWOOD & 56 & 80 \\
\hline 100 & W-8328 & FGS & Cuttings & -82.346449 & 28.631750 & NOBLETON & 97 & 262 \\
\hline 101 & W-8379 & FGS & Cuttings & -82.031089 & 28.866986 & WILDWOOD & 81 & 150 \\
\hline 102 & W-8381 & FGS & Cuttings & -82.212839 & 28.584093 & SAINT CATHERINE & 57 & 124 \\
\hline 103 & W-8429 & FGS & Cuttings & -82.402370 & 28.535904 & BROOKSVILLE & 100 & 105 \\
\hline 104 & W-8508 & FGS & Cuttings & -82.340156 & 28.530135 & BROOKSVILLE SE & 101 & 175 \\
\hline 105 & W-8604 & FGS & Cuttings & -82.405877 & 28.539779 & BROOKSVILLE & 84 & 208 \\
\hline 106 & W-8878 & FGS & Cuttings & -82.018495 & 28.837384 & WILDWOOD & 70 & 100 \\
\hline 107 & W-10299 & FGS & Cuttings & -82.393672 & 28.527105 & BROOKSVILLE & 205 & 325 \\
\hline 108 & W-10306 & FGS & Cuttings & -82.402502 & 28.550627 & BROOKSVILLE & 129 & 165 \\
\hline 109 & W-10331 & FGS & Cuttings & -82.050663 & 28.769439 & WILDWOOD & 70 & 565 \\
\hline 110 & W-10396 & FGS & Cuttings & -82.263645 & 28.521046 & BROOKSVILLE SE & 116 & 203 \\
\hline 111 & W-10464 & FGS & Cuttings & -82.234726 & 28.524722 & SAINT CATHERINE & 79 & 136 \\
\hline 112 & W-10465 & FGS & Cuttings & -82.024888 & 28.861443 & WILDWOOD & 65 & 409 \\
\hline 113 & W-10534 & FGS & Cuttings & -82.191424 & 28.503903 & SAINT CATHERINE & 72 & 150 \\
\hline 114 & W-10619 & FGS & Cuttings & -82.428650 & 28.898430 & HOLDER & 100 & 118 \\
\hline 115 & W-10622 & FGS & Cuttings & -82.025000 & 28.861389 & WILDWOOD & 65 & 700 \\
\hline 116 & W-10631 & FGS & Cuttings & -82.079841 & 28.617160 & WEBSTER & 80 & 130 \\
\hline 117 & W-10683 & FGS & Cuttings & -82.331555 & 28.504390 & SPRING LAKE & 116 & 445 \\
\hline 118 & W-10686 & FGS & Cuttings & -82.180075 & 28.506615 & SAINT CATHERINE & 65 & 115 \\
\hline 119 & W-10691 & FGS & Cuttings & -82.342692 & 28.570993 & BROOKSVILLE SE & 90 & 410 \\
\hline
\end{tabular}


FLORIDA GEOLOGICAL SURVEY

\begin{tabular}{|c|c|c|c|c|c|c|c|c|}
\hline $\begin{array}{l}\text { Map } \\
\text { ID }\end{array}$ & Well Label & Data Source & Sample Type & Longitude & Latitude & 24K Quad & $\begin{array}{c}\text { Elevation } \\
(\mathrm{ft})\end{array}$ & $\begin{array}{c}\text { Total } \\
\text { Depth }(\mathrm{ft})\end{array}$ \\
\hline 120 & W-10829 & FGS & Cuttings & -82.378372 & 28.835658 & LECANTO & 76 & 274 \\
\hline 121 & W-10937 & FGS & Cuttings & -82.045715 & 28.835873 & WILDWOOD & 60 & 250 \\
\hline 122 & W-11073 & FGS & Cuttings & -82.307575 & 28.795276 & INVERNESS & 50 & 95 \\
\hline 123 & W-11098 & FGS & Cuttings & -82.335694 & 28.840215 & INVERNESS & 53 & 800 \\
\hline 124 & W-11209 & FGS & Cuttings & -82.477102 & 28.514463 & BROOKSVILLE & 75 & 155 \\
\hline 125 & W-11218 & FGS & Cuttings & -82.310730 & 28.702647 & NOBLETON & 65 & 375 \\
\hline 126 & W-11220 & FGS & Cuttings & -82.309897 & 28.615123 & BROOKSVILLE SE & 50 & 300 \\
\hline 127 & W-11258 & FGS & Cuttings & -82.459534 & 28.928464 & HOLDER & 79 & 90 \\
\hline 128 & W-11260 & FGS & Cuttings & -82.492817 & 28.928038 & HOLDER & 110 & 200 \\
\hline 129 & W-11292 & FGS & Cuttings & -82.465152 & 28.541932 & BROOKSVILLE & 77 & 192 \\
\hline 130 & W-11293 & FGS & Cuttings & -82.458973 & 28.540733 & BROOKSVILLE & 96 & 137 \\
\hline 131 & W-11335 & FGS & Cuttings & -82.095228 & 28.879530 & OXFORD & 51 & 200 \\
\hline 132 & W-11422 & FGS & Cuttings & -82.096240 & 28.873110 & WILDWOOD & 50 & 200 \\
\hline 133 & W-11453 & FGS & Cuttings & -82.112411 & 28.762614 & WILDWOOD & 50 & 100 \\
\hline 134 & W-11564 & FGS & Cuttings & -82.078760 & 28.865040 & WILDWOOD & 63 & 163 \\
\hline 135 & W-11646 & FGS & Cuttings & -82.064130 & 28.618995 & WEBSTER & 85 & 190 \\
\hline 136 & W-11650 & FGS & Cuttings & -82.111783 & 28.879541 & OXFORD & 55 & 140 \\
\hline 137 & W-11653 & FGS & Cuttings & -82.311731 & 28.791601 & INVERNESS & 33 & 90 \\
\hline 138 & W-11662 & FGS & Cuttings & -82.105157 & 28.694487 & BUSHNELL & 69 & 150 \\
\hline 139 & W-11761 & FGS & Cuttings & -82.145831 & 28.631858 & WAHOO & 67 & 65 \\
\hline 140 & W-11784 & FGS & Cuttings & -82.177778 & 28.996156 & LAKE PANASOFFKEE NW & 77 & 112 \\
\hline 141 & W-11827 & FGS & Cuttings & -82.244526 & 28.865059 & RUTLAND & 40 & 96 \\
\hline 142 & W-11950 & FGS & Cuttings & -82.013464 & 28.646043 & BUSHNELL & 90 & 110 \\
\hline 143 & W-11995 & FGS & Cuttings & -82.095228 & 28.879530 & OXFORD & 49 & 250 \\
\hline 144 & W-12003 & FGS & Cuttings & -82.292692 & 28.529044 & BROOKSVILLE SE & 69 & 886 \\
\hline 145 & W-12057 & FGS & Cuttings & -82.091112 & 28.871880 & WILDWOOD & 57 & 170 \\
\hline 146 & W-12073 & FGS & Cuttings & -82.328373 & 28.821157 & INVERNESS & 63 & 95 \\
\hline 147 & W-12149 & FGS & Cuttings & -82.427014 & 28.958220 & HOLDER & 62 & 130 \\
\hline 148 & W-12179 & FGS & Cuttings & -82.029069 & 28.879691 & OXFORD & 72 & 153 \\
\hline 149 & W-12180 & FGS & Cuttings & -82.029069 & 28.879691 & OXFORD & 80 & 206 \\
\hline 150 & W-12194 & FGS & Cuttings & -82.477070 & 28.770887 & LECANTO & 65 & 94 \\
\hline 151 & W-12241 & FGS & Cuttings & -82.212638 & 28.820886 & RUTLAND & 42 & 60 \\
\hline 152 & W-12267 & FGS & Cuttings & -82.475719 & 28.840470 & LECANTO & 70 & 405 \\
\hline 153 & W-12873 & FGS & Cuttings & -82.294901 & 28.746297 & NOBLETON & 41 & 193 \\
\hline 154 & W-13137 & FGS & Cuttings & -82.476609 & 28.986748 & HOLDER & 74 & 110 \\
\hline 155 & W-13173 & FGS & Cuttings & -82.118889 & 28.777778 & WILDWOOD & 50 & 170 \\
\hline 156 & W-13350 & FGS & Cuttings & -82.037932 & 28.929384 & OXFORD & 100 & 100 \\
\hline 157 & W-13518 & FGS & Cuttings & -82.456511 & 28.656988 & BROOKSVILLE NW & 105 & 344.5 \\
\hline 158 & W-14265 & FGS & Cuttings & -82.359699 & 28.614530 & BROOKSVILLE SE & 95 & 185 \\
\hline 159 & W-14450 & FGS & Cuttings & -82.260628 & 28.645911 & NOBLETON & 51 & 37 \\
\hline 160 & W-14457 & FGS & Cuttings & -82.475917 & 28.913809 & HOLDER & 57 & 465 \\
\hline 161 & W-14661 & FGS & Cuttings & -82.442148 & 28.584764 & BROOKSVILLE & 86 & 452 \\
\hline 162 & W-14916 & FGS & Cuttings & -82.377290 & 28.716812 & BROOKSVILLE NW & 100 & 252 \\
\hline 163 & W-14917 & FGS & Cuttings & -82.364910 & 28.725311 & NOBLETON & 158 & 260 \\
\hline 164 & W-15063 & FGS & Cuttings & -82.292692 & 28.529044 & BROOKSVILLE SE & 69 & 410 \\
\hline 165 & W-15366 & FGS & Cuttings & -82.344055 & 28.701714 & NOBLETON & 80 & 400 \\
\hline 166 & W-15590 & FGS & Core & -82.054255 & 28.513861 & WEBSTER & 88 & 26.1 \\
\hline 167 & W-15596 & FGS & Core & -82.018999 & 28.506312 & WEBSTER & 93 & 23.9 \\
\hline 168 & W-15645 & FGS & Cuttings & -82.365000 & 28.724444 & NOBLETON & 158 & 284 \\
\hline 169 & W-15681 & FGS & Cuttings & -82.402222 & 28.556667 & BROOKSVILLE & 102 & 714.5 \\
\hline 170 & W-15838 & FGS & Cuttings & -82.096266 & 28.660796 & BUSHNELL & 83 & 710 \\
\hline 171 & W-15866 & FGS & Cuttings & -82.096389 & 28.660000 & BUSHNELL & 82 & 750 \\
\hline 172 & W-15992 & FGS & Cuttings & -82.382661 & 28.645559 & BROOKSVILLE NW & 155 & 115 \\
\hline 173 & W-16006 & FGS & Core & -82.153600 & 28.802977 & RUTLAND & 48 & 154 \\
\hline 174 & W-16253 & FGS & Cuttings & -82.181287 & 28.509234 & SAINT CATHERINE & 75 & 61 \\
\hline 175 & W-16310 & FGS & Core & -82.091977 & 28.748854 & BUSHNELL & 63 & 144.5 \\
\hline 176 & W-16617 & FGS & Core & -82.228303 & 28.880258 & LAKE PANASOFFKEE NW & 52 & 704 \\
\hline 177 & W-16644 & FGS & Core & -82.094825 & 28.799845 & WILDWOOD & 52 & 154 \\
\hline 178 & W-17659 & FGS & Cuttings & -82.011860 & 28.967790 & OXFORD & 69 & 101 \\
\hline 179 & W-18119 & FGS & Core & -82.465278 & 28.793056 & LECANTO & 107 & 51 \\
\hline 180 & W-18598 & FGS & Cuttings & -82.364861 & 28.725139 & NOBLETON & 157 & 29 \\
\hline
\end{tabular}


OPEN-FILE REPORT 96

\begin{tabular}{|c|c|c|c|c|c|c|c|c|}
\hline $\begin{array}{l}\text { Map } \\
\text { ID }\end{array}$ & Well Label & Data Source & Sample Type & Longitude & Latitude & 24K Quad & $\begin{array}{c}\text { Elevation } \\
(\mathrm{ft})\end{array}$ & $\begin{array}{c}\text { Total } \\
\text { Depth }(\mathrm{ft})\end{array}$ \\
\hline 181 & W-18599 & FGS & Core & -82.413833 & 28.856611 & LECANTO & 132 & 59 \\
\hline 182 & W-18604 & FGS & Core & -82.012222 & 28.938611 & OXFORD & 70 & 86.5 \\
\hline 183 & W-18680 & FGS & Core & -82.480589 & 28.738639 & BROOKSVILLE NW & 59 & 88 \\
\hline 184 & W-18800 & FGS & Core & -82.131690 & 28.843042 & RUTLAND & 44 & 48 \\
\hline 185 & W-18802 & FGS & Core & -82.147944 & 28.856944 & RUTLAND & 47 & 22 \\
\hline 186 & W-18804 & FGS & Core & -82.237028 & 28.601639 & SAINT CATHERINE & 73 & 1290 \\
\hline 187 & W-18988 & FGS & Core & -82.001594 & 28.829942 & WILDWOOD & 73 & 2037 \\
\hline 188 & W-19235 & FGS & Core & -82.305433 & 28.806864 & INVERNESS & 31 & 37 \\
\hline 189 & W-19245 & FGS & Core & -82.109158 & 28.650478 & BUSHNELL & 75 & 2157 \\
\hline 190 & W-19263 & FGS & Core & -82.385333 & 28.996472 & HOLDER & 28 & 75.7 \\
\hline 191 & W-50028 & FGS & Core & -82.413861 & 28.856567 & LECANTO & 132 & 182 \\
\hline 192 & 770539 & SWFWMD & Water Well & -82.410508 & 28.993897 & HOLDER & 76 & - \\
\hline 193 & 777685 & SWFWMD & Water Well & -82.495778 & 28.947500 & HOLDER & 117 & - \\
\hline 194 & 762005 & SWFWMD & Water Well & -82.354500 & 28.538922 & BROOKSVILLE SE & 105 & - \\
\hline 195 & 763021 & SWFWMD & Water Well & -82.283586 & 28.991633 & STOKES FERRY & 60 & - \\
\hline 196 & 768221 & SWFWMD & Water Well & -82.087722 & 28.583111 & WEBSTER & 79 & - \\
\hline 197 & 775568 & SWFWMD & Water Well & -82.001917 & 28.933528 & OXFORD & 78 & - \\
\hline 198 & 766863 & SWFWMD & Water Well & -82.005914 & 28.983058 & OXFORD & 93 & - \\
\hline 199 & 755175 & SWFWMD & Water Well & -82.024772 & 28.738319 & BUSHNELL & 81 & - \\
\hline 200 & 754407 & SWFWMD & Water Well & -82.025456 & 28.786850 & WILDWOOD & 75 & - \\
\hline 201 & 779954 & SWFWMD & Water Well & -82.026725 & 28.774589 & WILDWOOD & 76 & - \\
\hline 202 & 770795 & SWFWMD & Water Well & -82.027722 & 28.804117 & WILDWOOD & 64 & - \\
\hline 203 & 750703 & SWFWMD & Water Well & -82.029247 & 28.763161 & WILDWOOD & 68 & - \\
\hline 204 & 782775 & SWFWMD & Water Well & -82.032761 & 28.913164 & OXFORD & 78 & - \\
\hline 205 & 765500 & SWFWMD & Water Well & -82.032778 & 28.743278 & BUSHNELL & 75 & - \\
\hline 206 & 764921 & SWFWMD & Water Well & -82.033611 & 28.575333 & WEBSTER & 94 & - \\
\hline 207 & 781557 & SWFWMD & Water Well & -82.034942 & 28.881333 & OXFORD & 63 & - \\
\hline 208 & 776512 & SWFWMD & Water Well & -82.035633 & 28.756219 & WILDWOOD & 72 & - \\
\hline 209 & 774193 & SWFWMD & Water Well & -82.036194 & 28.804917 & WILDWOOD & 69 & - \\
\hline 210 & 765145 & SWFWMD & Water Well & -82.036508 & 28.936389 & OXFORD & 89 & - \\
\hline 211 & 772763 & SWFWMD & Water Well & -82.041122 & 28.959086 & OXFORD & 103 & - \\
\hline 212 & 770479 & SWFWMD & Water Well & -82.042217 & 28.597511 & WEBSTER & 90 & - \\
\hline 213 & 775696 & SWFWMD & Water Well & -82.043242 & 28.966972 & OXFORD & 98 & - \\
\hline 214 & 774187 & SWFWMD & Water Well & -82.045444 & 28.811806 & WILDWOOD & 64 & - \\
\hline 215 & 775863 & SWFWMD & Water Well & -82.046033 & 28.855072 & WILDWOOD & 61 & - \\
\hline 216 & 756280 & SWFWMD & Water Well & -82.046883 & 28.573311 & WEBSTER & 89 & - \\
\hline 217 & 762102 & SWFWMD & Water Well & -82.049167 & 28.802444 & WILDWOOD & 61 & - \\
\hline 218 & 764983 & SWFWMD & Water Well & -82.050611 & 28.812083 & WILDWOOD & 62 & - \\
\hline 219 & 780812 & SWFWMD & Water Well & -82.052389 & 28.576500 & WEBSTER & 88 & - \\
\hline 220 & 761527 & SWFWMD & Water Well & -82.054475 & 28.610097 & WEBSTER & 90 & - \\
\hline 221 & 761352 & SWFWMD & Water Well & -82.055806 & 28.708878 & BUSHNELL & 82 & - \\
\hline 222 & 771425 & SWFWMD & Water Well & -82.056194 & 28.712361 & BUSHNELL & 91 & - \\
\hline 223 & 756337 & SWFWMD & Water Well & -82.057108 & 28.666144 & BUSHNELL & 87 & - \\
\hline 224 & 756906 & SWFWMD & Water Well & -82.059583 & 28.798500 & WILDWOOD & 61 & - \\
\hline 225 & 776259 & SWFWMD & Water Well & -82.061367 & 28.687333 & BUSHNELL & 84 & - \\
\hline 226 & 763051 & SWFWMD & Water Well & -82.062389 & 28.667944 & BUSHNELL & 85 & - \\
\hline 227 & 761172 & SWFWMD & Water Well & -82.065833 & 28.734000 & BUSHNELL & 81 & - \\
\hline 228 & 772048 & SWFWMD & Water Well & -82.070425 & 28.678922 & BUSHNELL & 80 & - \\
\hline 229 & 777223 & SWFWMD & Water Well & -82.073647 & 28.664147 & BUSHNELL & 82 & - \\
\hline 230 & 766510 & SWFWMD & Water Well & -82.075583 & 28.619500 & WEBSTER & 85 & - \\
\hline 231 & 779871 & SWFWMD & Water Well & -82.078833 & 28.913928 & OXFORD & 58 & - \\
\hline 232 & 748019 & SWFWMD & Water Well & -82.079303 & 28.719644 & BUSHNELL & 78 & - \\
\hline 233 & 764791 & SWFWMD & Water Well & -82.081583 & 28.610194 & WEBSTER & 80 & - \\
\hline 234 & 780872 & SWFWMD & Water Well & -82.083006 & 28.716306 & BUSHNELL & 77 & - \\
\hline 235 & 784059 & SWFWMD & Water Well & -82.083667 & 28.717881 & BUSHNELL & 76 & - \\
\hline 236 & 782391 & SWFWMD & Water Well & -82.083803 & 28.930469 & OXFORD & 69 & - \\
\hline 237 & 768518 & SWFWMD & Water Well & -82.085222 & 28.582944 & WEBSTER & 80 & - \\
\hline 238 & 759951 & SWFWMD & Water Well & -82.085722 & 28.920806 & OXFORD & 72 & - \\
\hline 239 & 768478 & SWFWMD & Water Well & -82.086800 & 28.676567 & BUSHNELL & 78 & - \\
\hline 240 & 764178 & SWFWMD & Water Well & -82.086897 & 28.958206 & OXFORD & 64 & - \\
\hline 241 & 770435 & SWFWMD & Water Well & -82.090622 & 28.737114 & BUSHNELL & 80 & - \\
\hline
\end{tabular}


FLORIDA GEOLOGICAL SURVEY

\begin{tabular}{|c|c|c|c|c|c|c|c|c|}
\hline $\begin{array}{l}\text { Map } \\
\text { ID }\end{array}$ & Well Label & Data Source & Sample Type & Longitude & Latitude & 24K Quad & $\begin{array}{c}\text { Elevation } \\
(\mathrm{ft})\end{array}$ & $\begin{array}{c}\text { Total } \\
\text { Depth }(\mathrm{ft})\end{array}$ \\
\hline 242 & 783897 & SWFWMD & Water Well & -82.098517 & 28.611619 & WEBSTER & 72 & - \\
\hline 243 & 772800 & SWFWMD & Water Well & -82.101222 & 28.877389 & OXFORD & 55 & - \\
\hline 244 & 770616 & SWFWMD & Water Well & -82.101528 & 28.901528 & OXFORD & 60 & - \\
\hline 245 & 775383 & SWFWMD & Water Well & -82.103689 & 28.561383 & WEBSTER & 84 & - \\
\hline 246 & 750145 & SWFWMD & Water Well & -82.111614 & 28.952775 & OXFORD & 70 & - \\
\hline 247 & 764522 & SWFWMD & Water Well & -82.113944 & 28.753889 & WILDWOOD & 57 & - \\
\hline 248 & 755976 & SWFWMD & Water Well & -82.116597 & 28.983867 & OXFORD & 79 & - \\
\hline 249 & 770806 & SWFWMD & Water Well & -82.119278 & 28.671083 & BUSHNELL & 71 & - \\
\hline 250 & 764789 & SWFWMD & Water Well & -82.124556 & 28.646333 & BUSHNELL & 69 & - \\
\hline 251 & 781219 & SWFWMD & Water Well & -82.126139 & 28.657139 & WAHOO & 72 & - \\
\hline 252 & 770414 & SWFWMD & Water Well & -82.127803 & 28.767844 & RUTLAND & 51 & - \\
\hline 253 & 753001 & SWFWMD & Water Well & -82.128161 & 28.996469 & LAKE PANASOFFKEE NW & 82 & - \\
\hline 254 & 753917 & SWFWMD & Water Well & -82.128214 & 28.981872 & LAKE PANASOFFKEE NW & 61 & - \\
\hline 255 & 763808 & SWFWMD & Water Well & -82.134611 & 28.878056 & LAKE PANASOFFKEE NW & 80 & - \\
\hline 256 & 763008 & SWFWMD & Water Well & -82.136331 & 28.638081 & WAHOO & 66 & - \\
\hline 257 & 766513 & SWFWMD & Water Well & -82.137011 & 28.611300 & SAINT CATHERINE & 71 & - \\
\hline 258 & 755019 & SWFWMD & Water Well & -82.148028 & 28.654889 & WAHOO & 68 & - \\
\hline 259 & 772893 & SWFWMD & Water Well & -82.149531 & 28.565269 & SAINT CATHERINE & 74 & - \\
\hline 260 & 784753 & SWFWMD & Water Well & -82.156367 & 28.598239 & SAINT CATHERINE & 65 & - \\
\hline 261 & 769107 & SWFWMD & Water Well & -82.157194 & 28.680889 & WAHOO & 55 & - \\
\hline 262 & 761302 & SWFWMD & Water Well & -82.161583 & 28.581750 & SAINT CATHERINE & 77 & - \\
\hline 263 & 751120 & SWFWMD & Water Well & -82.162089 & 28.603117 & SAINT CATHERINE & 66 & - \\
\hline 264 & 776168 & SWFWMD & Water Well & -82.168583 & 28.523500 & SAINT CATHERINE & 65 & - \\
\hline 265 & 753693 & SWFWMD & Water Well & -82.168906 & 28.991808 & LAKE PANASOFFKEE NW & 99 & - \\
\hline 266 & 758133 & SWFWMD & Water Well & -82.170056 & 28.547139 & SAINT CATHERINE & 66 & - \\
\hline 267 & 773959 & SWFWMD & Water Well & -82.174372 & 28.841239 & RUTLAND & 50 & - \\
\hline 268 & 765347 & SWFWMD & Water Well & -82.175778 & 28.668750 & WAHOO & 52 & - \\
\hline 269 & 774755 & SWFWMD & Water Well & -82.177361 & 28.652583 & WAHOO & 56 & - \\
\hline 270 & 753294 & SWFWMD & Water Well & -82.178944 & 28.530403 & SAINT CATHERINE & 61 & - \\
\hline 271 & 772953 & SWFWMD & Water Well & -82.186250 & 28.521194 & SAINT CATHERINE & 69 & - \\
\hline 272 & 764977 & SWFWMD & Water Well & -82.186722 & 28.503389 & SAINT CATHERINE & 73 & - \\
\hline 273 & 774139 & SWFWMD & Water Well & -82.186778 & 28.576694 & SAINT CATHERINE & 58 & - \\
\hline 274 & 750639 & SWFWMD & Water Well & -82.188000 & 28.537028 & SAINT CATHERINE & 60 & - \\
\hline 275 & 763026 & SWFWMD & Water Well & -82.188444 & 28.607333 & SAINT CATHERINE & 58 & - \\
\hline 276 & 764267 & SWFWMD & Water Well & -82.190833 & 28.551444 & SAINT CATHERINE & 64 & - \\
\hline 277 & 766506 & SWFWMD & Water Well & -82.191889 & 28.562833 & SAINT CATHERINE & 68 & - \\
\hline 278 & 777981 & SWFWMD & Water Well & -82.192250 & 28.590861 & SAINT CATHERINE & 54 & - \\
\hline 279 & 771566 & SWFWMD & Water Well & -82.195058 & 28.526750 & SAINT CATHERINE & 67 & - \\
\hline 280 & 756219 & SWFWMD & Water Well & -82.202528 & 28.605444 & SAINT CATHERINE & 60 & - \\
\hline 281 & 783158 & SWFWMD & Water Well & -82.204550 & 28.626506 & WAHOO & 52 & - \\
\hline 282 & 776889 & SWFWMD & Water Well & -82.205861 & 28.507167 & SAINT CATHERINE & 68 & - \\
\hline 283 & 759149 & SWFWMD & Water Well & -82.206939 & 28.982197 & LAKE PANASOFFKEE NW & 79 & - \\
\hline 284 & 774376 & SWFWMD & Water Well & -82.213000 & 28.632806 & WAHOO & 54 & - \\
\hline 285 & 754812 & SWFWMD & Water Well & -82.215306 & 28.982786 & LAKE PANASOFFKEE NW & 64 & - \\
\hline 286 & 779251 & SWFWMD & Water Well & -82.228750 & 28.854833 & RUTLAND & 40 & - \\
\hline 287 & 771762 & SWFWMD & Water Well & -82.229361 & 28.709972 & WAHOO & 51 & - \\
\hline 288 & 780382 & SWFWMD & Water Well & -82.235344 & 28.522828 & SAINT CATHERINE & 78 & - \\
\hline 289 & 762976 & SWFWMD & Water Well & -82.236986 & 28.541197 & SAINT CATHERINE & 109 & - \\
\hline 290 & 776562 & SWFWMD & Water Well & -82.238250 & 28.861694 & RUTLAND & 39 & - \\
\hline 291 & 754728 & SWFWMD & Water Well & -82.244994 & 28.850689 & RUTLAND & 43 & - \\
\hline 292 & 783314 & SWFWMD & Water Well & -82.248622 & 28.651064 & WAHOO & 71 & - \\
\hline 293 & 749614 & SWFWMD & Water Well & -82.249611 & 28.869397 & RUTLAND & 45 & - \\
\hline 294 & 767966 & SWFWMD & Water Well & -82.254214 & 28.869781 & INVERNESS & 43 & - \\
\hline 295 & 757483 & SWFWMD & Water Well & -82.258083 & 28.744639 & NOBLETON & 45 & - \\
\hline 296 & 772332 & SWFWMD & Water Well & -82.258861 & 28.850289 & INVERNESS & 43 & - \\
\hline 297 & 772036 & SWFWMD & Water Well & -82.259111 & 28.853528 & INVERNESS & 42 & - \\
\hline 298 & 782925 & SWFWMD & Water Well & -82.263194 & 28.645472 & NOBLETON & 58 & - \\
\hline 299 & 770507 & SWFWMD & Water Well & -82.267139 & 28.530611 & BROOKSVILLE SE & 132 & - \\
\hline 300 & 764133 & SWFWMD & Water Well & -82.270453 & 28.661869 & NOBLETON & 49 & - \\
\hline 301 & 758584 & SWFWMD & Water Well & -82.270694 & 28.807639 & INVERNESS & 49 & - \\
\hline 302 & 758339 & SWFWMD & Water Well & -82.270722 & 28.826917 & INVERNESS & 59 & - \\
\hline
\end{tabular}


OPEN-FILE REPORT 96

\begin{tabular}{|c|c|c|c|c|c|c|c|c|}
\hline $\begin{array}{l}\text { Map } \\
\text { ID }\end{array}$ & Well Label & Data Source & Sample Type & Longitude & Latitude & 24K Quad & $\begin{array}{c}\text { Elevation } \\
\text { (ft) }\end{array}$ & $\begin{array}{c}\text { Total } \\
\text { Depth }(\mathrm{ft})\end{array}$ \\
\hline 303 & 772392 & SWFWMD & Water Well & -82.273014 & 28.672636 & NOBLETON & 68 & - \\
\hline 304 & 784469 & SWFWMD & Water Well & -82.276872 & 28.801433 & INVERNESS & 46 & - \\
\hline 305 & 775736 & SWFWMD & Water Well & -82.277694 & 28.661222 & NOBLETON & 56 & - \\
\hline 306 & 763078 & SWFWMD & Water Well & -82.278139 & 28.756556 & INVERNESS & 54 & - \\
\hline 307 & 772331 & SWFWMD & Water Well & -82.278350 & 28.828981 & INVERNESS & 58 & - \\
\hline 308 & 756602 & SWFWMD & Water Well & -82.278806 & 28.527611 & BROOKSVILLE SE & 138 & - \\
\hline 309 & 771433 & SWFWMD & Water Well & -82.283750 & 28.867889 & INVERNESS & 42 & - \\
\hline 310 & 780166 & SWFWMD & Water Well & -82.283806 & 28.792167 & INVERNESS & 41 & - \\
\hline 311 & 751644 & SWFWMD & Water Well & -82.295539 & 28.725436 & NOBLETON & 55 & - \\
\hline 312 & 762337 & SWFWMD & Water Well & -82.296278 & 28.771972 & INVERNESS & 49 & - \\
\hline 313 & 771503 & SWFWMD & Water Well & -82.296611 & 28.528417 & BROOKSVILLE SE & 85 & - \\
\hline 314 & 762999 & SWFWMD & Water Well & -82.296917 & 28.812500 & INVERNESS & 40 & - \\
\hline 315 & 763414 & SWFWMD & Water Well & -82.299306 & 28.730167 & NOBLETON & 58 & - \\
\hline 316 & 779782 & SWFWMD & Water Well & -82.300222 & 28.545194 & BROOKSVILLE SE & 155 & - \\
\hline 317 & 768668 & SWFWMD & Water Well & -82.301436 & 28.657989 & NOBLETON & 97 & - \\
\hline 318 & 751044 & SWFWMD & Water Well & -82.303217 & 28.777456 & INVERNESS & 32 & - \\
\hline 319 & 764393 & SWFWMD & Water Well & -82.305056 & 28.833333 & INVERNESS & 47 & - \\
\hline 320 & 765310 & SWFWMD & Water Well & -82.307139 & 28.528417 & BROOKSVILLE SE & 77 & - \\
\hline 321 & 774953 & SWFWMD & Water Well & -82.308186 & 28.874769 & INVERNESS & 44 & - \\
\hline 322 & 783632 & SWFWMD & Water Well & -82.308375 & 28.573758 & BROOKSVILLE SE & 88 & - \\
\hline 323 & 757750 & SWFWMD & Water Well & -82.310722 & 28.857694 & INVERNESS & 45 & - \\
\hline 324 & 774745 & SWFWMD & Water Well & -82.311444 & 28.874806 & INVERNESS & 43 & - \\
\hline 325 & 769852 & SWFWMD & Water Well & -82.311639 & 28.846361 & INVERNESS & 48 & - \\
\hline 326 & 774694 & SWFWMD & Water Well & -82.312083 & 28.561472 & BROOKSVILLE SE & 98 & - \\
\hline 327 & 766778 & SWFWMD & Water Well & -82.312917 & 28.567833 & BROOKSVILLE SE & 91 & - \\
\hline 328 & 758878 & SWFWMD & Water Well & -82.316417 & 28.611028 & BROOKSVILLE SE & 108 & - \\
\hline 329 & 764010 & SWFWMD & Water Well & -82.320708 & 28.603414 & BROOKSVILLE SE & 57 & - \\
\hline 330 & 766314 & SWFWMD & Water Well & -82.321033 & 28.777733 & INVERNESS & 60 & - \\
\hline 331 & 759543 & SWFWMD & Water Well & -82.322583 & 28.686972 & NOBLETON & 101 & - \\
\hline 332 & 766743 & SWFWMD & Water Well & -82.323833 & 28.592306 & BROOKSVILLE SE & 59 & - \\
\hline 333 & 763158 & SWFWMD & Water Well & -82.324508 & 28.512314 & BROOKSVILLE SE & 104 & - \\
\hline 334 & 768786 & SWFWMD & Water Well & -82.325139 & 28.559250 & BROOKSVILLE SE & 102 & - \\
\hline 335 & 753099 & SWFWMD & Water Well & -82.326314 & 28.586214 & BROOKSVILLE SE & 87 & - \\
\hline 336 & 767313 & SWFWMD & Water Well & -82.327444 & 28.524889 & BROOKSVILLE SE & 89 & - \\
\hline 337 & 783355 & SWFWMD & Water Well & -82.328228 & 28.605669 & BROOKSVILLE SE & 68 & - \\
\hline 338 & 777484 & SWFWMD & Water Well & -82.330039 & 28.835064 & INVERNESS & 46 & - \\
\hline 339 & 759411 & SWFWMD & Water Well & -82.330722 & 28.537444 & BROOKSVILLE SE & 82 & - \\
\hline 340 & 768603 & SWFWMD & Water Well & -82.331978 & 28.971675 & STOKES FERRY & 38 & - \\
\hline 341 & 765725 & SWFWMD & Water Well & -82.333528 & 28.779917 & INVERNESS & 80 & - \\
\hline 342 & 760285 & SWFWMD & Water Well & -82.336361 & 28.504639 & BROOKSVILLE SE & 127 & - \\
\hline 343 & 765220 & SWFWMD & Water Well & -82.338819 & 28.514275 & BROOKSVILLE SE & 156 & - \\
\hline 344 & 772865 & SWFWMD & Water Well & -82.340172 & 28.693344 & NOBLETON & 119 & - \\
\hline 345 & 776988 & SWFWMD & Water Well & -82.340556 & 28.597917 & BROOKSVILLE SE & 77 & - \\
\hline 346 & 767455 & SWFWMD & Water Well & -82.342694 & 28.597397 & BROOKSVILLE SE & 57 & - \\
\hline 347 & 751223 & SWFWMD & Water Well & -82.343592 & 28.838383 & INVERNESS & 90 & - \\
\hline 348 & 776836 & SWFWMD & Water Well & -82.344333 & 28.830444 & INVERNESS & 39 & - \\
\hline 349 & 773209 & SWFWMD & Water Well & -82.344556 & 28.803528 & INVERNESS & 46 & - \\
\hline 350 & 772039 & SWFWMD & Water Well & -82.345889 & 28.783889 & INVERNESS & 119 & - \\
\hline 351 & 777019 & SWFWMD & Water Well & -82.346056 & 28.525444 & BROOKSVILLE SE & 94 & - \\
\hline 352 & 779958 & SWFWMD & Water Well & -82.346381 & 28.860328 & INVERNESS & 50 & - \\
\hline 353 & 759968 & SWFWMD & Water Well & -82.349497 & 28.589650 & BROOKSVILLE SE & 100 & - \\
\hline 354 & 772047 & SWFWMD & Water Well & -82.350144 & 28.905331 & STOKES FERRY & 41 & - \\
\hline 355 & 765728 & SWFWMD & Water Well & -82.350833 & 28.822417 & INVERNESS & 115 & - \\
\hline 356 & 758224 & SWFWMD & Water Well & -82.351583 & 28.887083 & STOKES FERRY & 60 & - \\
\hline 357 & 768862 & SWFWMD & Water Well & -82.352372 & 28.897572 & STOKES FERRY & 37 & - \\
\hline 358 & 761110 & SWFWMD & Water Well & -82.355456 & 28.649161 & NOBLETON & 120 & - \\
\hline 359 & 778581 & SWFWMD & Water Well & -82.356450 & 28.573556 & BROOKSVILLE SE & 104 & - \\
\hline 360 & 767235 & SWFWMD & Water Well & -82.358083 & 28.523306 & BROOKSVILLE SE & 94 & - \\
\hline 361 & 761504 & SWFWMD & Water Well & -82.358592 & 28.671150 & NOBLETON & 123 & - \\
\hline 362 & 781135 & SWFWMD & Water Well & -82.359194 & 28.532417 & BROOKSVILLE SE & 106 & - \\
\hline 363 & 749770 & SWFWMD & Water Well & -82.359308 & 28.585800 & BROOKSVILLE SE & 105 & - \\
\hline
\end{tabular}


FLORIDA GEOLOGICAL SURVEY

\begin{tabular}{|c|c|c|c|c|c|c|c|c|}
\hline $\begin{array}{l}\text { Map } \\
\text { ID }\end{array}$ & Well Label & Data Source & Sample Type & Longitude & Latitude & 24K Quad & $\begin{array}{c}\text { Elevation } \\
(\mathrm{ft})\end{array}$ & $\begin{array}{c}\text { Total } \\
\text { Depth }(\mathrm{ft})\end{array}$ \\
\hline 364 & 772966 & SWFWMD & Water Well & -82.361142 & 28.674936 & NOBLETON & 119 & - \\
\hline 365 & 761434 & SWFWMD & Water Well & -82.361806 & 28.975333 & STOKES FERRY & 55 & - \\
\hline 366 & 756075 & SWFWMD & Water Well & -82.362056 & 28.568861 & BROOKSVILLE SE & 109 & - \\
\hline 367 & 777846 & SWFWMD & Water Well & -82.364583 & 28.948250 & STOKES FERRY & 37 & - \\
\hline 368 & 766721 & SWFWMD & Water Well & -82.365972 & 28.855861 & INVERNESS & 56 & - \\
\hline 369 & 757788 & SWFWMD & Water Well & -82.369611 & 28.554361 & BROOKSVILLE SE & 124 & - \\
\hline 370 & 768595 & SWFWMD & Water Well & -82.372519 & 28.549925 & BROOKSVILLE SE & 97 & - \\
\hline 371 & 778469 & SWFWMD & Water Well & -82.373694 & 28.714278 & NOBLETON & 66 & - \\
\hline 372 & 755687 & SWFWMD & Water Well & -82.375778 & 28.722361 & BROOKSVILLE NW & 136 & - \\
\hline 373 & 777155 & SWFWMD & Water Well & -82.376083 & 28.993250 & HOLDER & 48 & - \\
\hline 374 & 770351 & SWFWMD & Water Well & -82.377517 & 28.556433 & BROOKSVILLE & 143 & - \\
\hline 375 & 780490 & SWFWMD & Water Well & -82.381611 & 28.534806 & BROOKSVILLE & 119 & - \\
\hline 376 & 759049 & SWFWMD & Water Well & -82.384722 & 28.858389 & LECANTO & 102 & - \\
\hline 377 & 759378 & SWFWMD & Water Well & -82.385111 & 28.868528 & LECANTO & 78 & - \\
\hline 378 & 765674 & SWFWMD & Water Well & -82.387114 & 28.898414 & HOLDER & 70 & - \\
\hline 379 & 779373 & SWFWMD & Water Well & -82.388331 & 28.537806 & BROOKSVILLE & 136 & - \\
\hline 380 & 774232 & SWFWMD & Water Well & -82.389333 & 28.959917 & HOLDER & 58 & - \\
\hline 381 & 774971 & SWFWMD & Water Well & -82.391767 & 28.586106 & BROOKSVILLE & 145 & - \\
\hline 382 & 760413 & SWFWMD & Water Well & -82.393361 & 28.889694 & HOLDER & 87 & - \\
\hline 383 & 762177 & SWFWMD & Water Well & -82.398361 & 28.911083 & HOLDER & 87 & - \\
\hline 384 & 755400 & SWFWMD & Water Well & -82.400703 & 28.941308 & HOLDER & 67 & - \\
\hline 385 & 769926 & SWFWMD & Water Well & -82.402883 & 28.546200 & BROOKSVILLE & 112 & - \\
\hline 386 & 762175 & SWFWMD & Water Well & -82.406333 & 28.915861 & HOLDER & 95 & - \\
\hline 387 & 758170 & SWFWMD & Water Well & -82.411639 & 28.614694 & BROOKSVILLE & 79 & - \\
\hline 388 & 763117 & SWFWMD & Water Well & -82.411778 & 28.871139 & LECANTO & 85 & - \\
\hline 389 & 768376 & SWFWMD & Water Well & -82.412694 & 28.938028 & HOLDER & 79 & - \\
\hline 390 & 760921 & SWFWMD & Water Well & -82.415225 & 28.548392 & BROOKSVILLE & 90 & - \\
\hline 391 & 780431 & SWFWMD & Water Well & -82.418778 & 28.544361 & BROOKSVILLE & 77 & - \\
\hline 392 & 781059 & SWFWMD & Water Well & -82.421278 & 28.860389 & LECANTO & 130 & - \\
\hline 393 & 762211 & SWFWMD & Water Well & -82.422000 & 28.554169 & BROOKSVILLE & 88 & - \\
\hline 394 & 750832 & SWFWMD & Water Well & -82.423361 & 28.878611 & HOLDER & 119 & - \\
\hline 395 & 770659 & SWFWMD & Water Well & -82.424722 & 28.895139 & HOLDER & 98 & - \\
\hline 396 & 776623 & SWFWMD & Water Well & -82.426083 & 28.871194 & LECANTO & 117 & - \\
\hline 397 & 777676 & SWFWMD & Water Well & -82.427056 & 28.631556 & BROOKSVILLE NW & 107 & - \\
\hline 398 & 755692 & SWFWMD & Water Well & -82.429806 & 28.505111 & BROOKSVILLE & 78 & - \\
\hline 399 & 779516 & SWFWMD & Water Well & -82.437500 & 28.868389 & LECANTO & 151 & - \\
\hline 400 & 763733 & SWFWMD & Water Well & -82.444444 & 28.890917 & HOLDER & 194 & - \\
\hline 401 & 775957 & SWFWMD & Water Well & -82.446278 & 28.884250 & HOLDER & 95 & - \\
\hline 402 & 782246 & SWFWMD & Water Well & -82.448389 & 28.625278 & BROOKSVILLE NW & 94 & - \\
\hline 403 & 756400 & SWFWMD & Water Well & -82.451861 & 28.625500 & BROOKSVILLE NW & 91 & - \\
\hline 404 & 763022 & SWFWMD & Water Well & -82.453956 & 28.504997 & BROOKSVILLE & 66 & - \\
\hline 405 & 763734 & SWFWMD & Water Well & -82.455417 & 28.519917 & BROOKSVILLE & 72 & - \\
\hline 406 & 767421 & SWFWMD & Water Well & -82.459472 & 28.948056 & HOLDER & 98 & - \\
\hline 407 & 756954 & SWFWMD & Water Well & -82.460361 & 28.621528 & BROOKSVILLE & 112 & - \\
\hline 408 & 760670 & SWFWMD & Water Well & -82.461139 & 28.546361 & BROOKSVILLE & 114 & - \\
\hline 409 & 768695 & SWFWMD & Water Well & -82.463528 & 28.931778 & HOLDER & 83 & - \\
\hline 410 & 757655 & SWFWMD & Water Well & -82.463833 & 28.617806 & BROOKSVILLE & 159 & - \\
\hline 411 & 777591 & SWFWMD & Water Well & -82.464778 & 28.882778 & HOLDER & 88 & - \\
\hline 412 & 771151 & SWFWMD & Water Well & -82.467175 & 28.744667 & BROOKSVILLE NW & 56 & - \\
\hline 413 & 772459 & SWFWMD & Water Well & -82.471583 & 28.535306 & BROOKSVILLE & 81 & - \\
\hline 414 & 754354 & SWFWMD & Water Well & -82.472211 & 28.552939 & BROOKSVILLE & 93 & - \\
\hline 415 & 781981 & SWFWMD & Water Well & -82.475119 & 28.918781 & HOLDER & 101 & - \\
\hline 416 & 757028 & SWFWMD & Water Well & -82.477778 & 28.769194 & LECANTO & 61 & - \\
\hline 417 & 755313 & SWFWMD & Water Well & -82.478203 & 28.885328 & HOLDER & 83 & - \\
\hline 418 & 755838 & SWFWMD & Water Well & -82.479397 & 28.880706 & HOLDER & 72 & - \\
\hline 419 & 772339 & SWFWMD & Water Well & -82.481447 & 28.784489 & LECANTO & 47 & - \\
\hline 420 & 764586 & SWFWMD & Water Well & -82.481889 & 28.777500 & LECANTO & 43 & - \\
\hline 421 & 754827 & SWFWMD & Water Well & -82.483056 & 28.612000 & BROOKSVILLE & 114 & - \\
\hline 422 & 757734 & SWFWMD & Water Well & -82.483361 & 28.902806 & HOLDER & 91 & - \\
\hline 423 & 749639 & SWFWMD & Water Well & -82.485783 & 28.916842 & HOLDER & 117 & - \\
\hline 424 & 776929 & SWFWMD & Water Well & -82.488194 & 28.528111 & BROOKSVILLE & 61 & - \\
\hline
\end{tabular}


OPEN-FILE REPORT 96

\begin{tabular}{|c|c|c|c|c|c|c|c|c|}
\hline $\begin{array}{l}\text { Map } \\
\text { ID }\end{array}$ & Well Label & Data Source & Sample Type & Longitude & Latitude & 24K Quad & $\begin{array}{c}\text { Elevation } \\
(\mathrm{ft})\end{array}$ & $\begin{array}{c}\text { Total } \\
\text { Depth }(\mathrm{ft})\end{array}$ \\
\hline 425 & 759946 & SWFWMD & Water Well & -82.489067 & 28.848678 & LECANTO & 37 & - \\
\hline 426 & 749670 & SWFWMD & Water Well & -82.490139 & 28.945278 & HOLDER & 96 & - \\
\hline 427 & 764891 & SWFWMD & Water Well & -82.491750 & 28.641889 & BROOKSVILLE NW & 90 & - \\
\hline 428 & 775398 & SWFWMD & Water Well & -82.493092 & 28.897633 & HOLDER & 48 & - \\
\hline 429 & 756883 & SWFWMD & Water Well & -82.495361 & 28.626361 & BROOKSVILLE NW & 92 & - \\
\hline 430 & 754479 & SWFWMD & Water Well & -82.495417 & 28.783861 & LECANTO & 52 & - \\
\hline 431 & 759021 & SWFWMD & Water Well & -82.495417 & 28.664694 & BROOKSVILLE NW & 111 & - \\
\hline 432 & 771149 & SWFWMD & Water Well & -82.497481 & 28.763008 & LECANTO & 72 & - \\
\hline 433 & 776392 & SWFWMD & Water Well & -82.497694 & 28.529667 & BROOKSVILLE & 91 & - \\
\hline 434 & 778634 & SWFWMD & Water Well & -82.498139 & 28.578111 & BROOKSVILLE & 81 & - \\
\hline 435 & 779402 & SWFWMD & Water Well & -82.000147 & 28.831769 & WILDWOOD & 71 & - \\
\hline 436 & 769941 & SWFWMD & Water Well & -82.018750 & 28.916694 & OXFORD & 71 & - \\
\hline 437 & 755408 & SWFWMD & Water Well & -82.038931 & 28.960497 & OXFORD & 89 & - \\
\hline 438 & 773645 & SWFWMD & Water Well & -82.044639 & 28.888167 & OXFORD & 78 & - \\
\hline 439 & 783395 & SWFWMD & Water Well & -82.055369 & 28.911922 & OXFORD & 107 & - \\
\hline 440 & 769603 & SWFWMD & Water Well & -82.062083 & 28.926222 & OXFORD & 71 & - \\
\hline 441 & 758669 & SWFWMD & Water Well & -82.062500 & 28.907667 & OXFORD & 63 & - \\
\hline 442 & 764881 & SWFWMD & Water Well & -82.070775 & 28.927550 & OXFORD & 66 & - \\
\hline 443 & 782440 & SWFWMD & Water Well & -82.073619 & 28.902244 & OXFORD & 65 & - \\
\hline 444 & 783386 & SWFWMD & Water Well & -82.080400 & 28.979553 & OXFORD & 57 & - \\
\hline 445 & 766315 & SWFWMD & Water Well & -82.080472 & 28.940250 & OXFORD & 60 & - \\
\hline 446 & 773268 & SWFWMD & Water Well & -82.084056 & 28.951806 & OXFORD & 64 & - \\
\hline 447 & 772798 & SWFWMD & Water Well & -82.085286 & 28.987408 & OXFORD & 71 & - \\
\hline 448 & 780408 & SWFWMD & Water Well & -82.087386 & 28.927364 & OXFORD & 66 & - \\
\hline 449 & 762056 & SWFWMD & Water Well & -82.090306 & 28.891500 & OXFORD & 71 & - \\
\hline 450 & 756535 & SWFWMD & Water Well & -82.095767 & 28.960431 & OXFORD & 66 & - \\
\hline 451 & 780257 & SWFWMD & Water Well & -82.097592 & 28.968703 & OXFORD & 67 & - \\
\hline 452 & 762204 & SWFWMD & Water Well & -82.097653 & 28.982678 & OXFORD & 71 & - \\
\hline 453 & 771539 & SWFWMD & Water Well & -82.097722 & 28.905167 & OXFORD & 75 & - \\
\hline 454 & 752176 & SWFWMD & Water Well & -82.098000 & 28.995544 & OXFORD & 65 & - \\
\hline 455 & 754140 & SWFWMD & Water Well & -82.106075 & 28.991869 & OXFORD & 68 & - \\
\hline 456 & 775639 & SWFWMD & Water Well & -82.125778 & 28.910667 & LAKE PANASOFFKEE NW & 80 & - \\
\hline 457 & 756297 & SWFWMD & Water Well & -82.157636 & 28.985208 & LAKE PANASOFFKEE NW & 77 & - \\
\hline 458 & 776879 & SWFWMD & Water Well & -82.162047 & 28.990883 & LAKE PANASOFFKEE NW & 83 & - \\
\hline 459 & 755902 & SWFWMD & Water Well & -82.195744 & 28.970267 & LAKE PANASOFFKEE NW & 72 & - \\
\hline 460 & 772913 & SWFWMD & Water Well & -82.208422 & 28.991681 & LAKE PANASOFFKEE NW & 70 & - \\
\hline 461 & 780236 & SWFWMD & Water Well & -82.267144 & 28.995744 & STOKES FERRY & 52 & - \\
\hline 462 & 779182 & SWFWMD & Water Well & -82.301061 & 28.886772 & STOKES FERRY & 38 & - \\
\hline 463 & 768821 & SWFWMD & Water Well & -82.353028 & 28.980753 & STOKES FERRY & 42 & - \\
\hline 464 & 774351 & SWFWMD & Water Well & -82.364167 & 28.924278 & STOKES FERRY & 42 & - \\
\hline 465 & 772270 & SWFWMD & Water Well & -82.375639 & 28.906131 & HOLDER & 47 & - \\
\hline 466 & 782954 & SWFWMD & Water Well & -82.385417 & 28.928500 & HOLDER & 45 & - \\
\hline 467 & 753527 & SWFWMD & Water Well & -82.394264 & 28.938997 & HOLDER & 44 & - \\
\hline 468 & 779272 & SWFWMD & Water Well & -82.402833 & 28.967167 & HOLDER & 54 & - \\
\hline 469 & 759589 & SWFWMD & Water Well & -82.414500 & 28.995278 & HOLDER & 62 & - \\
\hline 470 & 754428 & SWFWMD & Water Well & -82.417483 & 28.980697 & HOLDER & 57 & - \\
\hline 471 & 770868 & SWFWMD & Water Well & -82.435828 & 28.994286 & HOLDER & 80 & - \\
\hline 472 & 748379 & SWFWMD & Water Well & -82.429111 & 28.905833 & HOLDER & 35 & - \\
\hline 473 & 763789 & SWFWMD & Water Well & -82.296128 & 28.652817 & NOBLETON & 87 & - \\
\hline 474 & 773743 & SWFWMD & Water Well & -82.119261 & 28.618772 & WEBSTER & 76 & - \\
\hline 475 & 772846 & SWFWMD & Water Well & -82.008619 & 28.741556 & BUSHNELL & 82 & - \\
\hline 476 & 784453 & SWFWMD & Water Well & -82.008933 & 28.649028 & BUSHNELL & 94 & - \\
\hline 477 & 771940 & SWFWMD & Water Well & -82.009317 & 28.634378 & BUSHNELL & 95 & - \\
\hline 478 & 782351 & SWFWMD & Water Well & -82.015047 & 28.795150 & WILDWOOD & 80 & - \\
\hline 479 & 783165 & SWFWMD & Water Well & -82.017697 & 28.961756 & OXFORD & 90 & - \\
\hline 480 & 778537 & SWFWMD & Water Well & -82.017889 & 28.563222 & WEBSTER & 106 & - \\
\hline 481 & 758924 & SWFWMD & Water Well & -82.019972 & 28.984206 & OXFORD & 77 & - \\
\hline 482 & 763483 & SWFWMD & Water Well & -82.022822 & 28.877167 & OXFORD & 69 & - \\
\hline 483 & 772573 & SWFWMD & Water Well & -82.024219 & 28.610181 & WEBSTER & 94 & - \\
\hline 484 & 759958 & SWFWMD & Water Well & -82.024306 & 28.781428 & WILDWOOD & 85 & - \\
\hline 485 & 773464 & SWFWMD & Water Well & -82.024839 & 28.760136 & WILDWOOD & 80 & - \\
\hline
\end{tabular}


FLORIDA GEOLOGICAL SURVEY

\begin{tabular}{|c|c|c|c|c|c|c|c|c|}
\hline $\begin{array}{l}\text { Map } \\
\text { ID }\end{array}$ & Well Label & Data Source & Sample Type & Longitude & Latitude & 24K Quad & $\begin{array}{c}\text { Elevation } \\
(\mathrm{ft})\end{array}$ & $\begin{array}{c}\text { Total } \\
\text { Depth }(\mathrm{ft})\end{array}$ \\
\hline 486 & 751728 & SWFWMD & Water Well & -82.029342 & 28.733878 & BUSHNELL & 76 & - \\
\hline 487 & 766894 & SWFWMD & Water Well & -82.029739 & 28.817561 & WILDWOOD & 69 & - \\
\hline 488 & 752343 & SWFWMD & Water Well & -82.030008 & 28.588078 & WEBSTER & 89 & - \\
\hline 489 & 763062 & SWFWMD & Water Well & -82.031972 & 28.560028 & WEBSTER & 98 & - \\
\hline 490 & 768737 & SWFWMD & Water Well & -82.034542 & 28.649503 & BUSHNELL & 93 & - \\
\hline 491 & 759962 & SWFWMD & Water Well & -82.040894 & 28.784314 & WILDWOOD & 52 & - \\
\hline 492 & 764614 & SWFWMD & Water Well & -82.041722 & 28.712056 & BUSHNELL & 83 & - \\
\hline 493 & 757203 & SWFWMD & Water Well & -82.042167 & 28.853583 & WILDWOOD & 60 & - \\
\hline 494 & 775028 & SWFWMD & Water Well & -82.044472 & 28.610978 & WEBSTER & 92 & - \\
\hline 495 & 779363 & SWFWMD & Water Well & -82.050417 & 28.644000 & BUSHNELL & 90 & - \\
\hline 496 & 776511 & SWFWMD & Water Well & -82.052514 & 28.767778 & WILDWOOD & 67 & - \\
\hline 497 & 781584 & SWFWMD & Water Well & -82.053361 & 28.549917 & WEBSTER & 87 & - \\
\hline 498 & 765219 & SWFWMD & Water Well & -82.058631 & 28.862306 & WILDWOOD & 59 & - \\
\hline 499 & 770036 & SWFWMD & Water Well & -82.059300 & 28.688014 & BUSHNELL & 85 & - \\
\hline 500 & 777246 & SWFWMD & Water Well & -82.059361 & 28.680306 & BUSHNELL & 85 & - \\
\hline 501 & 765121 & SWFWMD & Water Well & -82.060917 & 28.704000 & BUSHNELL & 83 & - \\
\hline 502 & 767417 & SWFWMD & Water Well & -82.061167 & 28.547083 & WEBSTER & 82 & - \\
\hline 503 & 778386 & SWFWMD & Water Well & -82.061478 & 28.849017 & WILDWOOD & 56 & - \\
\hline 504 & 751291 & SWFWMD & Water Well & -82.062422 & 28.748703 & BUSHNELL & 71 & - \\
\hline 505 & 775691 & SWFWMD & Water Well & -82.064358 & 28.553722 & WEBSTER & 82 & - \\
\hline 506 & 751147 & SWFWMD & Water Well & -82.071417 & 28.779750 & WILDWOOD & 58 & - \\
\hline 507 & 760409 & SWFWMD & Water Well & -82.071831 & 28.788061 & WILDWOOD & 61 & - \\
\hline 508 & 775641 & SWFWMD & Water Well & -82.074378 & 28.801119 & WILDWOOD & 57 & - \\
\hline 509 & 777192 & SWFWMD & Water Well & -82.074603 & 28.540358 & WEBSTER & 80 & - \\
\hline 510 & 781787 & SWFWMD & Water Well & -82.075033 & 28.550478 & WEBSTER & 81 & - \\
\hline 511 & 769783 & SWFWMD & Water Well & -82.078506 & 28.812450 & WILDWOOD & 50 & - \\
\hline 512 & 752535 & SWFWMD & Water Well & -82.078528 & 28.982072 & OXFORD & 64 & - \\
\hline 513 & 747257 & SWFWMD & Water Well & -82.079089 & 28.748733 & BUSHNELL & 69 & - \\
\hline 514 & 759660 & SWFWMD & Water Well & -82.079611 & 28.649417 & BUSHNELL & 81 & - \\
\hline 515 & 756697 & SWFWMD & Water Well & -82.086517 & 28.747833 & BUSHNELL & 65 & - \\
\hline 516 & 773871 & SWFWMD & Water Well & -82.086761 & 28.631106 & BUSHNELL & 80 & - \\
\hline 517 & 772766 & SWFWMD & Water Well & -82.088539 & 28.696000 & BUSHNELL & 74 & - \\
\hline 518 & 775759 & SWFWMD & Water Well & -82.089739 & 28.579133 & WEBSTER & 79 & - \\
\hline 519 & 757768 & SWFWMD & Water Well & -82.090917 & 28.543611 & WEBSTER & 84 & - \\
\hline 520 & 749724 & SWFWMD & Water Well & -82.093611 & 28.516333 & WEBSTER & 83 & - \\
\hline 521 & 768439 & SWFWMD & Water Well & -82.103556 & 28.656333 & BUSHNELL & 77 & - \\
\hline 522 & 768976 & SWFWMD & Water Well & -82.104694 & 28.745278 & BUSHNELL & 60 & - \\
\hline 523 & 759703 & SWFWMD & Water Well & -82.105197 & 28.700194 & BUSHNELL & 68 & - \\
\hline 524 & 777366 & SWFWMD & Water Well & -82.105806 & 28.612972 & WEBSTER & 75 & - \\
\hline 525 & 754049 & SWFWMD & Water Well & -82.107828 & 28.561750 & WEBSTER & 82 & - \\
\hline 526 & 762847 & SWFWMD & Water Well & -82.114194 & 28.916333 & OXFORD & 56 & - \\
\hline 527 & 774134 & SWFWMD & Water Well & -82.115611 & 28.770444 & WILDWOOD & 44 & - \\
\hline 528 & 773302 & SWFWMD & Water Well & -82.123039 & 28.642750 & BUSHNELL & 71 & - \\
\hline 529 & 753161 & SWFWMD & Water Well & -82.128217 & 28.952728 & LAKE PANASOFFKEE NW & 68 & - \\
\hline 530 & 753416 & SWFWMD & Water Well & -82.128258 & 28.879886 & LAKE PANASOFFKEE NW & 47 & - \\
\hline 531 & 767977 & SWFWMD & Water Well & -82.128408 & 28.681239 & WAHOO & 64 & - \\
\hline 532 & 753361 & SWFWMD & Water Well & -82.128797 & 28.748933 & WAHOO & 55 & - \\
\hline 533 & 759479 & SWFWMD & Water Well & -82.135167 & 28.939528 & LAKE PANASOFFKEE NW & 64 & - \\
\hline 534 & 766016 & SWFWMD & Water Well & -82.138083 & 28.773083 & RUTLAND & 47 & - \\
\hline 535 & 775427 & SWFWMD & Water Well & -82.139131 & 28.809819 & RUTLAND & 39 & - \\
\hline 536 & 779364 & SWFWMD & Water Well & -82.139389 & 28.769653 & RUTLAND & 47 & - \\
\hline 537 & 774002 & SWFWMD & Water Well & -82.140758 & 28.606669 & SAINT CATHERINE & 72 & - \\
\hline 538 & 758911 & SWFWMD & Water Well & -82.147056 & 28.805572 & RUTLAND & 46 & - \\
\hline 539 & 750868 & SWFWMD & Water Well & -82.147697 & 28.564233 & SAINT CATHERINE & 74 & - \\
\hline 540 & 776384 & SWFWMD & Water Well & -82.152117 & 28.597803 & SAINT CATHERINE & 68 & - \\
\hline 541 & 766515 & SWFWMD & Water Well & -82.155472 & 28.682267 & WAHOO & 55 & - \\
\hline 542 & 757818 & SWFWMD & Water Well & -82.157142 & 28.968386 & LAKE PANASOFFKEE NW & 84 & - \\
\hline 543 & 772949 & SWFWMD & Water Well & -82.157786 & 28.537403 & SAINT CATHERINE & 71 & - \\
\hline 544 & 763178 & SWFWMD & Water Well & -82.158650 & 28.650289 & WAHOO & 64 & - \\
\hline 545 & 760095 & SWFWMD & Water Well & -82.159181 & 28.821408 & RUTLAND & 51 & - \\
\hline 546 & 751119 & SWFWMD & Water Well & -82.162008 & 28.617650 & SAINT CATHERINE & 65 & - \\
\hline
\end{tabular}


OPEN-FILE REPORT 96

\begin{tabular}{|c|c|c|c|c|c|c|c|c|}
\hline $\begin{array}{l}\text { Map } \\
\text { ID }\end{array}$ & Well Label & Data Source & Sample Type & Longitude & Latitude & 24K Quad & $\begin{array}{c}\text { Elevation } \\
(\mathrm{ft})\end{array}$ & $\begin{array}{c}\text { Total } \\
\text { Depth }(\mathrm{ft})\end{array}$ \\
\hline 547 & 752139 & SWFWMD & Water Well & -82.162406 & 28.530372 & SAINT CATHERINE & 72 & - \\
\hline 548 & 762237 & SWFWMD & Water Well & -82.169200 & 28.508733 & SAINT CATHERINE & 75 & - \\
\hline 549 & 767318 & SWFWMD & Water Well & -82.173431 & 28.679228 & WAHOO & 49 & - \\
\hline 550 & 762952 & SWFWMD & Water Well & -82.176389 & 28.642472 & WAHOO & 59 & - \\
\hline 551 & 778938 & SWFWMD & Water Well & -82.177178 & 28.859481 & RUTLAND & 57 & - \\
\hline 552 & 757958 & SWFWMD & Water Well & -82.180722 & 28.819944 & RUTLAND & 40 & - \\
\hline 553 & 778454 & SWFWMD & Water Well & -82.182333 & 28.797722 & RUTLAND & 43 & - \\
\hline 554 & 762062 & SWFWMD & Water Well & -82.183917 & 28.826889 & RUTLAND & 42 & - \\
\hline 555 & 774345 & SWFWMD & Water Well & -82.186917 & 28.641611 & WAHOO & 52 & - \\
\hline 556 & 754656 & SWFWMD & Water Well & -82.190425 & 28.990594 & LAKE PANASOFFKEE NW & 88 & - \\
\hline 557 & 769272 & SWFWMD & Water Well & -82.193139 & 28.675444 & WAHOO & 46 & - \\
\hline 558 & 756005 & SWFWMD & Water Well & -82.195500 & 28.533083 & SAINT CATHERINE & 59 & - \\
\hline 559 & 783615 & SWFWMD & Water Well & -82.196342 & 28.649456 & WAHOO & 53 & - \\
\hline 560 & 768642 & SWFWMD & Water Well & -82.196806 & 28.619861 & SAINT CATHERINE & 53 & - \\
\hline 561 & 759397 & SWFWMD & Water Well & -82.197583 & 28.559833 & SAINT CATHERINE & 63 & - \\
\hline 562 & 767162 & SWFWMD & Water Well & -82.204111 & 28.871750 & RUTLAND & 50 & - \\
\hline 563 & 750315 & SWFWMD & Water Well & -82.204192 & 28.585467 & SAINT CATHERINE & 58 & - \\
\hline 564 & 777952 & SWFWMD & Water Well & -82.205833 & 28.642250 & WAHOO & 50 & - \\
\hline 565 & 769432 & SWFWMD & Water Well & -82.206222 & 28.857500 & RUTLAND & 50 & - \\
\hline 566 & 767343 & SWFWMD & Water Well & -82.207556 & 28.845972 & RUTLAND & 42 & - \\
\hline 567 & 777344 & SWFWMD & Water Well & -82.209583 & 28.509028 & SAINT CATHERINE & 58 & - \\
\hline 568 & 774903 & SWFWMD & Water Well & -82.216694 & 28.600336 & SAINT CATHERINE & 64 & - \\
\hline 569 & 754715 & SWFWMD & Water Well & -82.217875 & 28.729881 & WAHOO & 45 & - \\
\hline 570 & 773347 & SWFWMD & Water Well & -82.218944 & 28.838150 & RUTLAND & 43 & - \\
\hline 571 & 762650 & SWFWMD & Water Well & -82.220444 & 28.636222 & WAHOO & 61 & - \\
\hline 572 & 773543 & SWFWMD & Water Well & -82.220633 & 28.612650 & SAINT CATHERINE & 70 & - \\
\hline 573 & 758382 & SWFWMD & Water Well & -82.225694 & 28.717344 & WAHOO & 49 & - \\
\hline 574 & 774800 & SWFWMD & Water Well & -82.227083 & 28.848222 & RUTLAND & 40 & - \\
\hline 575 & 755013 & SWFWMD & Water Well & -82.227586 & 28.709817 & WAHOO & 43 & - \\
\hline 576 & 754268 & SWFWMD & Water Well & -82.228861 & 28.749669 & WAHOO & 47 & - \\
\hline 577 & 766210 & SWFWMD & Water Well & -82.231306 & 28.756167 & RUTLAND & 45 & - \\
\hline 578 & 768000 & SWFWMD & Water Well & -82.235556 & 28.642667 & WAHOO & 54 & - \\
\hline 579 & 766053 & SWFWMD & Water Well & -82.235889 & 28.651806 & WAHOO & 50 & - \\
\hline 580 & 751912 & SWFWMD & Water Well & -82.239417 & 28.515889 & SAINT CATHERINE & 93 & - \\
\hline 581 & 765097 & SWFWMD & Water Well & -82.239722 & 28.756139 & RUTLAND & 45 & - \\
\hline 582 & 752776 & SWFWMD & Water Well & -82.243139 & 28.705056 & WAHOO & 47 & - \\
\hline 583 & 763678 & SWFWMD & Water Well & -82.244250 & 28.754528 & RUTLAND & 49 & - \\
\hline 584 & 767336 & SWFWMD & Water Well & -82.246444 & 28.629500 & WAHOO & 57 & - \\
\hline 585 & 764868 & SWFWMD & Water Well & -82.250736 & 28.667678 & NOBLETON & 59 & - \\
\hline 586 & 755841 & SWFWMD & Water Well & -82.252750 & 28.561111 & BROOKSVILLE SE & 94 & - \\
\hline 587 & 769969 & SWFWMD & Water Well & -82.253136 & 28.634725 & NOBLETON & 47 & - \\
\hline 588 & 770150 & SWFWMD & Water Well & -82.254000 & 28.690111 & NOBLETON & 42 & - \\
\hline 589 & 773702 & SWFWMD & Water Well & -82.254469 & 28.526203 & BROOKSVILLE SE & 107 & - \\
\hline 590 & 759234 & SWFWMD & Water Well & -82.254750 & 28.826806 & INVERNESS & 52 & - \\
\hline 591 & 780193 & SWFWMD & Water Well & -82.255069 & 28.535417 & BROOKSVILLE SE & 92 & - \\
\hline 592 & 756480 & SWFWMD & Water Well & -82.255083 & 28.693028 & NOBLETON & 52 & - \\
\hline 593 & 776818 & SWFWMD & Water Well & -82.256167 & 28.875194 & STOKES FERRY & 41 & - \\
\hline 594 & 755271 & SWFWMD & Water Well & -82.258833 & 28.822722 & INVERNESS & 52 & - \\
\hline 595 & 771836 & SWFWMD & Water Well & -82.260017 & 28.735783 & NOBLETON & 56 & - \\
\hline 596 & 765253 & SWFWMD & Water Well & -82.261906 & 28.640547 & NOBLETON & 52 & - \\
\hline 597 & 779380 & SWFWMD & Water Well & -82.262569 & 28.995556 & STOKES FERRY & 50 & - \\
\hline 598 & 769087 & SWFWMD & Water Well & -82.265583 & 28.759694 & INVERNESS & 42 & - \\
\hline 599 & 756290 & SWFWMD & Water Well & -82.266472 & 28.512389 & BROOKSVILLE SE & 169 & - \\
\hline 600 & 775991 & SWFWMD & Water Well & -82.267019 & 28.810169 & INVERNESS & 47 & - \\
\hline 601 & 762603 & SWFWMD & Water Well & -82.277156 & 28.770703 & INVERNESS & 44 & - \\
\hline 602 & 763844 & SWFWMD & Water Well & -82.278192 & 28.678075 & NOBLETON & 46 & - \\
\hline 603 & 767226 & SWFWMD & Water Well & -82.278972 & 28.742917 & NOBLETON & 49 & - \\
\hline 604 & 764554 & SWFWMD & Water Well & -82.284603 & 28.874783 & INVERNESS & 44 & - \\
\hline 605 & 779762 & SWFWMD & Water Well & -82.284667 & 28.544500 & BROOKSVILLE SE & 87 & - \\
\hline 606 & 783163 & SWFWMD & Water Well & -82.287169 & 28.515939 & BROOKSVILLE SE & 91 & - \\
\hline 607 & 759966 & SWFWMD & Water Well & -82.288947 & 28.668281 & NOBLETON & 98 & - \\
\hline
\end{tabular}


FLORIDA GEOLOGICAL SURVEY

\begin{tabular}{|c|c|c|c|c|c|c|c|c|}
\hline $\begin{array}{l}\text { Map } \\
\text { ID }\end{array}$ & Well Label & Data Source & Sample Type & Longitude & Latitude & 24K Quad & $\begin{array}{c}\text { Elevation } \\
\text { (ft) }\end{array}$ & $\begin{array}{c}\text { Total } \\
\text { Depth }(\mathrm{ft})\end{array}$ \\
\hline 608 & 761591 & SWFWMD & Water Well & -82.293917 & 28.694750 & NOBLETON & 83 & - \\
\hline 609 & 758496 & SWFWMD & Water Well & -82.296028 & 28.689306 & NOBLETON & 73 & - \\
\hline 610 & 781590 & SWFWMD & Water Well & -82.296364 & 28.897836 & STOKES FERRY & 48 & - \\
\hline 611 & 772398 & SWFWMD & Water Well & -82.300861 & 28.567694 & BROOKSVILLE SE & 89 & - \\
\hline 612 & 761815 & SWFWMD & Water Well & -82.302639 & 28.645528 & NOBLETON & 107 & - \\
\hline 613 & 766256 & SWFWMD & Water Well & -82.305069 & 28.587164 & BROOKSVILLE SE & 170 & - \\
\hline 614 & 783725 & SWFWMD & Water Well & -82.307089 & 28.513731 & BROOKSVILLE SE & 80 & - \\
\hline 615 & 763149 & SWFWMD & Water Well & -82.308100 & 28.625444 & NOBLETON & 61 & - \\
\hline 616 & 779359 & SWFWMD & Water Well & -82.309306 & 28.552722 & BROOKSVILLE SE & 101 & - \\
\hline 617 & 775864 & SWFWMD & Water Well & -82.310425 & 28.900261 & STOKES FERRY & 40 & - \\
\hline 618 & 757551 & SWFWMD & Water Well & -82.310583 & 28.616889 & BROOKSVILLE SE & 79 & - \\
\hline 619 & 759646 & SWFWMD & Water Well & -82.311083 & 28.731333 & NOBLETON & 52 & - \\
\hline 620 & 752345 & SWFWMD & Water Well & -82.313892 & 28.757672 & INVERNESS & 72 & - \\
\hline 621 & 763868 & SWFWMD & Water Well & -82.314261 & 28.665989 & NOBLETON & 124 & - \\
\hline 622 & 775121 & SWFWMD & Water Well & -82.315222 & 28.882033 & STOKES FERRY & 47 & - \\
\hline 623 & 761136 & SWFWMD & Water Well & -82.315614 & 28.685728 & NOBLETON & 89 & - \\
\hline 624 & 781748 & SWFWMD & Water Well & -82.316283 & 28.753383 & INVERNESS & 70 & - \\
\hline 625 & 765874 & SWFWMD & Water Well & -82.318583 & 28.640828 & NOBLETON & 114 & - \\
\hline 626 & 752563 & SWFWMD & Water Well & -82.327483 & 28.571481 & BROOKSVILLE SE & 102 & - \\
\hline 627 & 776961 & SWFWMD & Water Well & -82.328639 & 28.967833 & STOKES FERRY & 42 & - \\
\hline 628 & 780195 & SWFWMD & Water Well & -82.329861 & 28.552781 & BROOKSVILLE SE & 92 & - \\
\hline 629 & 759072 & SWFWMD & Water Well & -82.330722 & 28.855583 & INVERNESS & 45 & - \\
\hline 630 & 770842 & SWFWMD & Water Well & -82.331333 & 28.621500 & BROOKSVILLE SE & 107 & - \\
\hline 631 & 769801 & SWFWMD & Water Well & -82.333106 & 28.693972 & NOBLETON & 120 & - \\
\hline 632 & 759953 & SWFWMD & Water Well & -82.338250 & 28.639936 & NOBLETON & 100 & - \\
\hline 633 & 768272 & SWFWMD & Water Well & -82.338361 & 28.579750 & BROOKSVILLE SE & 93 & - \\
\hline 634 & 761493 & SWFWMD & Water Well & -82.343417 & 28.542694 & BROOKSVILLE SE & 103 & - \\
\hline 635 & 754906 & SWFWMD & Water Well & -82.348861 & 28.874583 & INVERNESS & 40 & - \\
\hline 636 & 780163 & SWFWMD & Water Well & -82.349056 & 28.634917 & NOBLETON & 141 & - \\
\hline 637 & 772435 & SWFWMD & Water Well & -82.349361 & 28.786806 & INVERNESS & 126 & - \\
\hline 638 & 758538 & SWFWMD & Water Well & -82.351861 & 28.735000 & NOBLETON & 77 & - \\
\hline 639 & 770327 & SWFWMD & Water Well & -82.352294 & 28.695822 & NOBLETON & 111 & - \\
\hline 640 & 772564 & SWFWMD & Water Well & -82.352903 & 28.756614 & INVERNESS & 53 & - \\
\hline 641 & 755235 & SWFWMD & Water Well & -82.354553 & 28.752778 & INVERNESS & 83 & - \\
\hline 642 & 769275 & SWFWMD & Water Well & -82.354639 & 28.596028 & BROOKSVILLE SE & 94 & - \\
\hline 643 & 761114 & SWFWMD & Water Well & -82.355375 & 28.651103 & NOBLETON & 154 & - \\
\hline 644 & 759467 & SWFWMD & Water Well & -82.356611 & 28.684556 & NOBLETON & 117 & - \\
\hline 645 & 755323 & SWFWMD & Water Well & -82.356639 & 28.801803 & INVERNESS & 58 & - \\
\hline 646 & 778387 & SWFWMD & Water Well & -82.357944 & 28.666056 & NOBLETON & 91 & - \\
\hline 647 & 768940 & SWFWMD & Water Well & -82.358972 & 28.715472 & NOBLETON & 117 & - \\
\hline 648 & 753058 & SWFWMD & Water Well & -82.360861 & 28.919972 & STOKES FERRY & 43 & - \\
\hline 649 & 779074 & SWFWMD & Water Well & -82.361222 & 28.634861 & NOBLETON & 105 & - \\
\hline 650 & 768121 & SWFWMD & Water Well & -82.363028 & 28.833556 & INVERNESS & 73 & - \\
\hline 651 & 782199 & SWFWMD & Water Well & -82.364722 & 28.571333 & BROOKSVILLE SE & 116 & - \\
\hline 652 & 760705 & SWFWMD & Water Well & -82.368861 & 28.735167 & NOBLETON & 156 & - \\
\hline 653 & 755963 & SWFWMD & Water Well & -82.369222 & 28.514083 & BROOKSVILLE SE & 130 & - \\
\hline 654 & 782319 & SWFWMD & Water Well & -82.373467 & 28.501975 & BROOKSVILLE SE & 147 & - \\
\hline 655 & 780284 & SWFWMD & Water Well & -82.376194 & 28.704722 & BROOKSVILLE NW & 117 & - \\
\hline 656 & 772096 & SWFWMD & Water Well & -82.377194 & 28.648722 & BROOKSVILLE NW & 203 & - \\
\hline 657 & 750040 & SWFWMD & Water Well & -82.377219 & 28.731750 & BROOKSVILLE NW & 114 & - \\
\hline 658 & 753736 & SWFWMD & Water Well & -82.378194 & 28.678694 & BROOKSVILLE NW & 118 & - \\
\hline 659 & 762135 & SWFWMD & Water Well & -82.379222 & 28.729667 & BROOKSVILLE NW & 116 & - \\
\hline 660 & 781030 & SWFWMD & Water Well & -82.381889 & 28.599778 & BROOKSVILLE & 115 & - \\
\hline 661 & 758791 & SWFWMD & Water Well & -82.382611 & 28.531222 & BROOKSVILLE & 172 & - \\
\hline 662 & 763530 & SWFWMD & Water Well & -82.383258 & 28.603239 & BROOKSVILLE & 139 & - \\
\hline 663 & 761943 & SWFWMD & Water Well & -82.384917 & 28.828472 & LECANTO & 31 & - \\
\hline 664 & 776059 & SWFWMD & Water Well & -82.387906 & 28.698625 & BROOKSVILLE NW & 67 & - \\
\hline 665 & 778067 & SWFWMD & Water Well & -82.391664 & 28.583778 & BROOKSVILLE & 119 & - \\
\hline 666 & 765899 & SWFWMD & Water Well & -82.395333 & 28.603333 & BROOKSVILLE & 99 & - \\
\hline 667 & 780568 & SWFWMD & Water Well & -82.399111 & 28.552583 & BROOKSVILLE & 128 & - \\
\hline 668 & 780771 & SWFWMD & Water Well & -82.402972 & 28.641667 & BROOKSVILLE NW & 121 & - \\
\hline
\end{tabular}


OPEN-FILE REPORT 96

\begin{tabular}{|c|c|c|c|c|c|c|c|c|}
\hline $\begin{array}{l}\text { Map } \\
\text { ID }\end{array}$ & Well Label & Data Source & Sample Type & Longitude & Latitude & 24K Quad & $\begin{array}{c}\text { Elevation } \\
(\mathrm{ft})\end{array}$ & $\begin{array}{c}\text { Total } \\
\text { Depth }(\mathrm{ft})\end{array}$ \\
\hline 669 & 763763 & SWFWMD & Water Well & -82.406000 & 28.578333 & BROOKSVILLE & 219 & - \\
\hline 670 & 762796 & SWFWMD & Water Well & -82.408181 & 28.529478 & BROOKSVILLE & 98 & - \\
\hline 671 & 764550 & SWFWMD & Water Well & -82.408425 & 28.579333 & BROOKSVILLE & 242 & - \\
\hline 672 & 758033 & SWFWMD & Water Well & -82.412611 & 28.612972 & BROOKSVILLE & 80 & - \\
\hline 673 & 755771 & SWFWMD & Water Well & -82.414961 & 28.863161 & LECANTO & 129 & - \\
\hline 674 & 759538 & SWFWMD & Water Well & -82.417028 & 28.620417 & BROOKSVILLE & 90 & - \\
\hline 675 & 764917 & SWFWMD & Water Well & -82.418636 & 28.534181 & BROOKSVILLE & 70 & - \\
\hline 676 & 771985 & SWFWMD & Water Well & -82.420306 & 28.559500 & BROOKSVILLE & 103 & - \\
\hline 677 & 782622 & SWFWMD & Water Well & -82.421778 & 28.503739 & BROOKSVILLE & 82 & - \\
\hline 678 & 768874 & SWFWMD & Water Well & -82.426753 & 28.676444 & BROOKSVILLE NW & 60 & - \\
\hline 679 & 762132 & SWFWMD & Water Well & -82.427144 & 28.636364 & BROOKSVILLE NW & 117 & - \\
\hline 680 & 756640 & SWFWMD & Water Well & -82.429194 & 28.855250 & LECANTO & 123 & - \\
\hline 681 & 755683 & SWFWMD & Water Well & -82.439500 & 28.658222 & BROOKSVILLE NW & 111 & - \\
\hline 682 & 751058 & SWFWMD & Water Well & -82.441881 & 28.782836 & LECANTO & 46 & - \\
\hline 683 & 752956 & SWFWMD & Water Well & -82.443081 & 28.900047 & HOLDER & 154 & - \\
\hline 684 & 783367 & SWFWMD & Water Well & -82.445997 & 28.624097 & BROOKSVILLE & 90 & - \\
\hline 685 & 762232 & SWFWMD & Water Well & -82.449000 & 28.944164 & HOLDER & 64 & - \\
\hline 686 & 781041 & SWFWMD & Water Well & -82.450167 & 28.859000 & LECANTO & 122 & - \\
\hline 687 & 773288 & SWFWMD & Water Well & -82.451800 & 28.787167 & LECANTO & 64 & - \\
\hline 688 & 766371 & SWFWMD & Water Well & -82.452742 & 28.574525 & BROOKSVILLE & 93 & - \\
\hline 689 & 765349 & SWFWMD & Water Well & -82.454278 & 28.619972 & BROOKSVILLE & 105 & - \\
\hline 690 & 782195 & SWFWMD & Water Well & -82.454417 & 28.770361 & LECANTO & 72 & - \\
\hline 691 & 751659 & SWFWMD & Water Well & -82.455406 & 28.971164 & HOLDER & 121 & - \\
\hline 692 & 764101 & SWFWMD & Water Well & -82.462750 & 28.758556 & LECANTO & 70 & - \\
\hline 693 & 771145 & SWFWMD & Water Well & -82.466469 & 28.742181 & BROOKSVILLE NW & 77 & - \\
\hline 694 & 778155 & SWFWMD & Water Well & -82.467700 & 28.587592 & BROOKSVILLE & 99 & - \\
\hline 695 & 757333 & SWFWMD & Water Well & -82.469500 & 28.857278 & LECANTO & 51 & - \\
\hline 696 & 784237 & SWFWMD & Water Well & -82.471775 & 28.666161 & BROOKSVILLE NW & 86 & - \\
\hline 697 & 770191 & SWFWMD & Water Well & -82.472333 & 28.789083 & LECANTO & 50 & - \\
\hline 698 & 779513 & SWFWMD & Water Well & -82.473111 & 28.613278 & BROOKSVILLE & 113 & - \\
\hline 699 & 768146 & SWFWMD & Water Well & -82.475531 & 28.588378 & BROOKSVILLE & 134 & - \\
\hline 700 & 780080 & SWFWMD & Water Well & -82.475694 & 28.642722 & BROOKSVILLE NW & 137 & - \\
\hline 701 & 784070 & SWFWMD & Water Well & -82.476406 & 28.943572 & HOLDER & 90 & - \\
\hline 702 & 751563 & SWFWMD & Water Well & -82.476525 & 28.754253 & LECANTO & 49 & - \\
\hline 703 & 771016 & SWFWMD & Water Well & -82.478722 & 28.557778 & BROOKSVILLE & 85 & - \\
\hline 704 & 773401 & SWFWMD & Water Well & -82.478944 & 28.553111 & BROOKSVILLE & 75 & - \\
\hline 705 & 763452 & SWFWMD & Water Well & -82.484594 & 28.671850 & BROOKSVILLE NW & 79 & - \\
\hline 706 & 768361 & SWFWMD & Water Well & -82.486897 & 28.847217 & LECANTO & 46 & - \\
\hline 707 & 755158 & SWFWMD & Water Well & -82.488992 & 28.609392 & BROOKSVILLE & 137 & - \\
\hline 708 & 780143 & SWFWMD & Water Well & -82.491331 & 28.824811 & LECANTO & 74 & - \\
\hline 709 & 765348 & SWFWMD & Water Well & -82.492167 & 28.717281 & BROOKSVILLE NW & 68 & - \\
\hline 710 & 760721 & SWFWMD & Water Well & -82.493833 & 28.584111 & BROOKSVILLE & 84 & - \\
\hline 711 & 765702 & SWFWMD & Water Well & -82.494028 & 28.990528 & HOLDER & 113 & - \\
\hline 712 & 782722 & SWFWMD & Water Well & -82.498194 & 28.753472 & LECANTO & 83 & - \\
\hline 713 & Big Jones Creek & SWFWMD & Water Well & -82.114722 & 28.856944 & WILDWOOD & 43 & - \\
\hline 714 & 1563 & SWFWMD & Water Well & -82.222000 & 28.754000 & RUTLAND & 41 & - \\
\hline 715 & 744877 & SWFWMD & Water Well & -82.012108 & 28.952800 & OXFORD & 70 & - \\
\hline 716 & 750036 & SWFWMD & Water Well & -82.012197 & 28.909039 & OXFORD & 72 & - \\
\hline 717 & 749081 & SWFWMD & Water Well & -82.012242 & 28.894536 & OXFORD & 65 & - \\
\hline 718 & 753923 & SWFWMD & Water Well & -82.045353 & 28.938347 & OXFORD & 81 & - \\
\hline 719 & 753030 & SWFWMD & Water Well & -82.049925 & 28.898364 & OXFORD & 98 & - \\
\hline 720 & 760147 & SWFWMD & Water Well & -82.058228 & 28.954425 & OXFORD & 69 & - \\
\hline 721 & 769952 & SWFWMD & Water Well & -82.074306 & 28.952833 & OXFORD & 70 & - \\
\hline 722 & 773569 & SWFWMD & Water Well & -82.079444 & 28.891306 & OXFORD & 88 & - \\
\hline 723 & 775638 & SWFWMD & Water Well & -82.103056 & 28.923639 & OXFORD & 61 & - \\
\hline 724 & 765203 & SWFWMD & Water Well & -82.107389 & 28.936139 & OXFORD & 67 & - \\
\hline 725 & 768214 & SWFWMD & Water Well & -82.113906 & 28.895036 & OXFORD & 81 & - \\
\hline 726 & 782976 & SWFWMD & Water Well & -82.126278 & 28.974056 & LAKE PANASOFFKEE NW & 59 & - \\
\hline 727 & 759661 & SWFWMD & Water Well & -82.133806 & 28.897472 & LAKE PANASOFFKEE NW & 77 & - \\
\hline 728 & 761245 & SWFWMD & Water Well & -82.134500 & 28.918000 & LAKE PANASOFFKEE NW & 58 & - \\
\hline 729 & 773211 & SWFWMD & Water Well & -82.138997 & 28.952881 & LAKE PANASOFFKEE NW & 67 & - \\
\hline
\end{tabular}


FLORIDA GEOLOGICAL SURVEY

\begin{tabular}{|c|c|c|c|c|c|c|c|c|}
\hline $\begin{array}{l}\text { Map } \\
\text { ID }\end{array}$ & Well Label & Data Source & Sample Type & Longitude & Latitude & 24K Quad & $\begin{array}{c}\text { Elevation } \\
(\mathrm{ft})\end{array}$ & $\begin{array}{c}\text { Total } \\
\text { Depth }(\mathrm{ft})\end{array}$ \\
\hline 730 & 753431 & SWFWMD & Water Well & -82.144822 & 28.879825 & LAKE PANASOFFKEE NW & 77 & - \\
\hline 731 & 753619 & SWFWMD & Water Well & -82.150611 & 28.890083 & LAKE PANASOFFKEE NW & 73 & - \\
\hline 732 & 755880 & SWFWMD & Water Well & -82.166011 & 28.962297 & LAKE PANASOFFKEE NW & 86 & - \\
\hline 733 & 770329 & SWFWMD & Water Well & -82.182378 & 28.960144 & LAKE PANASOFFKEE NW & 77 & - \\
\hline 734 & 754387 & SWFWMD & Water Well & -82.193986 & 28.961164 & LAKE PANASOFFKEE NW & 87 & - \\
\hline 735 & 770207 & SWFWMD & Water Well & -82.214572 & 28.979833 & LAKE PANASOFFKEE NW & 58 & - \\
\hline 736 & 750883 & SWFWMD & Water Well & -82.227619 & 28.996836 & LAKE PANASOFFKEE NW & 60 & - \\
\hline 737 & 754517 & SWFWMD & Water Well & -82.250797 & 28.994447 & STOKES FERRY & 50 & - \\
\hline 738 & 772465 & SWFWMD & Water Well & -82.294889 & 28.993439 & STOKES FERRY & 55 & - \\
\hline 739 & 779217 & SWFWMD & Water Well & -82.320056 & 28.965389 & STOKES FERRY & 40 & - \\
\hline 740 & 760871 & SWFWMD & Water Well & -82.345944 & 28.967028 & STOKES FERRY & 38 & - \\
\hline 741 & 769827 & SWFWMD & Water Well & -82.350011 & 28.908147 & STOKES FERRY & 41 & - \\
\hline 742 & 776117 & SWFWMD & Water Well & -82.404611 & 28.893333 & HOLDER & 106 & - \\
\hline 743 & 760342 & SWFWMD & Water Well & -82.418067 & 28.925058 & HOLDER & 62 & - \\
\hline 744 & 769163 & SWFWMD & Water Well & -82.433542 & 28.977811 & HOLDER & 52 & - \\
\hline 745 & 759801 & SWFWMD & Water Well & -82.468483 & 28.918689 & HOLDER & 104 & - \\
\hline 746 & 761068 & SWFWMD & Water Well & -82.471042 & 28.892761 & HOLDER & 68 & - \\
\hline 747 & 756629 & SWFWMD & Water Well & -82.019506 & 28.999000 & OXFORD & 75 & - \\
\hline 748 & 775556 & SWFWMD & Water Well & -82.495889 & 28.975583 & HOLDER & 92 & - \\
\hline 749 & 763360 & SWFWMD & Water Well & -82.134164 & 28.882053 & LAKE PANASOFFKEE NW & 80 & - \\
\hline 750 & 768416 & SWFWMD & Water Well & -82.141306 & 28.889250 & LAKE PANASOFFKEE NW & 72 & - \\
\hline 751 & 761937 & SWFWMD & Water Well & -82.142444 & 28.883167 & LAKE PANASOFFKEE NW & 66 & - \\
\hline 752 & 755085 & SWFWMD & Water Well & -82.158692 & 28.976353 & LAKE PANASOFFKEE NW & 89 & - \\
\hline 753 & 775598 & SWFWMD & Water Well & -82.166556 & 28.973472 & LAKE PANASOFFKEE NW & 89 & - \\
\hline 754 & 752726 & SWFWMD & Water Well & -82.167586 & 28.968389 & LAKE PANASOFFKEE NW & 94 & - \\
\hline 755 & 761716 & SWFWMD & Water Well & -82.175231 & 28.964922 & LAKE PANASOFFKEE NW & 86 & - \\
\hline 756 & 754551 & SWFWMD & Water Well & -82.184003 & 28.965406 & LAKE PANASOFFKEE NW & 73 & - \\
\hline 757 & 764796 & SWFWMD & Water Well & -82.211875 & 28.985844 & LAKE PANASOFFKEE NW & 69 & - \\
\hline 758 & 741478 & SWFWMD & Water Well & -82.217519 & 28.996772 & LAKE PANASOFFKEE NW & 72 & - \\
\hline 759 & 768384 & SWFWMD & Water Well & -82.026722 & 28.894306 & OXFORD & 71 & - \\
\hline 760 & 769836 & SWFWMD & Water Well & -82.005131 & 28.996583 & OXFORD & 85 & - \\
\hline 761 & 754209 & SWFWMD & Water Well & -82.009167 & 28.988519 & OXFORD & 79 & - \\
\hline 762 & 754535 & SWFWMD & Water Well & -82.013125 & 28.988547 & OXFORD & 100 & - \\
\hline 763 & 760026 & SWFWMD & Water Well & -82.022000 & 28.901667 & OXFORD & 65 & - \\
\hline 764 & 780128 & SWFWMD & Water Well & -82.025278 & 28.931972 & OXFORD & 106 & - \\
\hline 765 & 771354 & SWFWMD & Water Well & -82.026875 & 28.887586 & OXFORD & 65 & - \\
\hline 766 & 774474 & SWFWMD & Water Well & -82.031011 & 28.885431 & OXFORD & 70 & - \\
\hline 767 & 782238 & SWFWMD & Water Well & -82.041500 & 28.890639 & OXFORD & 80 & - \\
\hline 768 & 772400 & SWFWMD & Water Well & -82.054833 & 28.949944 & OXFORD & 78 & - \\
\hline 769 & 770953 & SWFWMD & Water Well & -82.057944 & 28.947556 & OXFORD & 61 & - \\
\hline 770 & 772151 & SWFWMD & Water Well & -82.060361 & 28.914361 & OXFORD & 64 & - \\
\hline 771 & 760538 & SWFWMD & Water Well & -82.082806 & 28.897528 & OXFORD & 66 & - \\
\hline 772 & 754289 & SWFWMD & Water Well & -82.086142 & 28.924017 & OXFORD & 69 & - \\
\hline 773 & 756031 & SWFWMD & Water Well & -82.105011 & 28.971517 & OXFORD & 58 & - \\
\hline 774 & 771843 & SWFWMD & Water Well & -82.109261 & 28.961767 & OXFORD & 58 & - \\
\hline 775 & 778720 & SWFWMD & Water Well & -82.112219 & 28.967114 & OXFORD & 71 & - \\
\hline 776 & 778218 & SWFWMD & Water Well & -82.065444 & 28.914444 & OXFORD & 63 & - \\
\hline 777 & 755509 & SWFWMD & Water Well & -82.071550 & 28.936775 & OXFORD & 65 & - \\
\hline 778 & 760753 & SWFWMD & Water Well & -82.085417 & 28.902083 & OXFORD & 67 & - \\
\hline 779 & 778114 & SWFWMD & Water Well & -82.110333 & 28.979286 & OXFORD & 76 & - \\
\hline 780 & 761370 & SWFWMD & Water Well & -82.051444 & 28.810361 & WILDWOOD & 65 & - \\
\hline 781 & 765295 & SWFWMD & Water Well & -82.057878 & 28.806389 & WILDWOOD & 63 & - \\
\hline 782 & 779399 & SWFWMD & Water Well & -82.070139 & 28.800094 & WILDWOOD & 62 & - \\
\hline 783 & 778244 & SWFWMD & Water Well & -82.181250 & 28.825083 & RUTLAND & 48 & - \\
\hline 784 & 768477 & SWFWMD & Water Well & -82.274417 & 28.810222 & INVERNESS & 49 & - \\
\hline 785 & 772586 & SWFWMD & Water Well & -82.280333 & 28.844444 & INVERNESS & 46 & - \\
\hline 786 & 765168 & SWFWMD & Water Well & -82.283944 & 28.771306 & INVERNESS & 50 & - \\
\hline 787 & 770030 & SWFWMD & Water Well & -82.289750 & 28.862250 & INVERNESS & 45 & - \\
\hline 788 & 755769 & SWFWMD & Water Well & -82.298522 & 28.862553 & INVERNESS & 44 & - \\
\hline 789 & 756888 & SWFWMD & Water Well & -82.299194 & 28.776833 & INVERNESS & 50 & - \\
\hline 790 & 762815 & SWFWMD & Water Well & -82.302806 & 28.843694 & INVERNESS & 40 & - \\
\hline
\end{tabular}


OPEN-FILE REPORT 96

\begin{tabular}{|c|c|c|c|c|c|c|c|c|}
\hline $\begin{array}{l}\text { Map } \\
\text { ID }\end{array}$ & Well Label & Data Source & Sample Type & Longitude & Latitude & 24K Quad & $\begin{array}{c}\text { Elevation } \\
(\mathrm{ft})\end{array}$ & $\begin{array}{c}\text { Total } \\
\text { Depth }(\mathrm{ft})\end{array}$ \\
\hline 791 & 767308 & SWFWMD & Water Well & -82.305611 & 28.827417 & INVERNESS & 51 & - \\
\hline 792 & 763237 & SWFWMD & Water Well & -82.310972 & 28.819083 & INVERNESS & 51 & - \\
\hline 793 & 757320 & SWFWMD & Water Well & -82.320250 & 28.814611 & INVERNESS & 71 & - \\
\hline 794 & 767460 & SWFWMD & Water Well & -82.326639 & 28.804556 & INVERNESS & 61 & - \\
\hline 795 & 772772 & SWFWMD & Water Well & -82.331083 & 28.785806 & INVERNESS & 70 & - \\
\hline 796 & 756817 & SWFWMD & Water Well & -82.333194 & 28.798417 & INVERNESS & 71 & - \\
\hline 797 & 762581 & SWFWMD & Water Well & -82.333389 & 28.815361 & INVERNESS & 65 & - \\
\hline 798 & 764287 & SWFWMD & Water Well & -82.340056 & 28.781678 & INVERNESS & 116 & - \\
\hline 799 & 759140 & SWFWMD & Water Well & -82.342694 & 28.790306 & INVERNESS & 81 & - \\
\hline 800 & 766760 & SWFWMD & Water Well & -82.348889 & 28.864611 & INVERNESS & 42 & - \\
\hline 801 & 754838 & SWFWMD & Water Well & -82.355167 & 28.866111 & INVERNESS & 59 & - \\
\hline 802 & 757308 & SWFWMD & Water Well & -82.363139 & 28.868806 & INVERNESS & 65 & - \\
\hline 803 & 778610 & SWFWMD & Water Well & -82.367750 & 28.860472 & INVERNESS & 77 & - \\
\hline 804 & 757696 & SWFWMD & Water Well & -82.371583 & 28.865722 & INVERNESS & 68 & - \\
\hline 805 & 755259 & SWFWMD & Water Well & -82.377358 & 28.867319 & LECANTO & 58 & - \\
\hline 806 & 774299 & SWFWMD & Water Well & -82.377972 & 28.857833 & LECANTO & 72 & - \\
\hline 807 & 782054 & SWFWMD & Water Well & -82.415767 & 28.869733 & LECANTO & 118 & - \\
\hline 808 & 750876 & SWFWMD & Water Well & -82.442953 & 28.870728 & LECANTO & 143 & - \\
\hline 809 & 762721 & SWFWMD & Water Well & -82.458775 & 28.766667 & LECANTO & 82 & - \\
\hline 810 & 765151 & SWFWMD & Water Well & -82.464556 & 28.866194 & LECANTO & 98 & - \\
\hline 811 & 761740 & SWFWMD & Water Well & -82.470361 & 28.760750 & LECANTO & 55 & - \\
\hline 812 & 771720 & SWFWMD & Water Well & -82.477147 & 28.783661 & LECANTO & 64 & - \\
\hline 813 & 753011 & SWFWMD & Water Well & -82.497933 & 28.835444 & LECANTO & 48 & - \\
\hline 814 & 782105 & SWFWMD & Water Well & -82.035306 & 28.579956 & WEBSTER & 97 & - \\
\hline 815 & 757099 & SWFWMD & Water Well & -82.046444 & 28.593333 & WEBSTER & 88 & - \\
\hline 816 & 770206 & SWFWMD & Water Well & -82.046750 & 28.728333 & BUSHNELL & 83 & - \\
\hline 817 & 775026 & SWFWMD & Water Well & -82.051806 & 28.724028 & BUSHNELL & 84 & - \\
\hline 818 & 777447 & SWFWMD & Water Well & -82.055222 & 28.650478 & BUSHNELL & 88 & - \\
\hline 819 & 753360 & SWFWMD & Water Well & -82.062544 & 28.734133 & BUSHNELL & 82 & - \\
\hline 820 & 765801 & SWFWMD & Water Well & -82.065506 & 28.609008 & WEBSTER & 89 & - \\
\hline 821 & 763764 & SWFWMD & Water Well & -82.066367 & 28.742933 & BUSHNELL & 71 & - \\
\hline 822 & 781308 & SWFWMD & Water Well & -82.067022 & 28.618772 & WEBSTER & 87 & - \\
\hline 823 & 777076 & SWFWMD & Water Well & -82.069619 & 28.602214 & WEBSTER & 86 & - \\
\hline 824 & 767522 & SWFWMD & Water Well & -82.069967 & 28.635536 & BUSHNELL & 86 & - \\
\hline 825 & 756643 & SWFWMD & Water Well & -82.077242 & 28.593717 & WEBSTER & 80 & - \\
\hline 826 & 751148 & SWFWMD & Water Well & -82.096058 & 28.690408 & BUSHNELL & 72 & - \\
\hline 827 & 760407 & SWFWMD & Water Well & -82.098694 & 28.697861 & BUSHNELL & 67 & - \\
\hline 828 & 772946 & SWFWMD & Water Well & -82.099808 & 28.671333 & BUSHNELL & 80 & - \\
\hline 829 & 761039 & SWFWMD & Water Well & -82.109389 & 28.670389 & BUSHNELL & 76 & - \\
\hline 830 & 781000 & SWFWMD & Water Well & -82.142469 & 28.656261 & WAHOO & 65 & - \\
\hline 831 & 773377 & SWFWMD & Water Well & -82.157903 & 28.564794 & SAINT CATHERINE & 69 & - \\
\hline 832 & 761003 & SWFWMD & Water Well & -82.161528 & 28.569389 & SAINT CATHERINE & 65 & - \\
\hline 833 & 760857 & SWFWMD & Water Well & -82.164833 & 28.536139 & SAINT CATHERINE & 79 & - \\
\hline 834 & 756307 & SWFWMD & Water Well & -82.170806 & 28.568119 & SAINT CATHERINE & 67 & - \\
\hline 835 & 771218 & SWFWMD & Water Well & -82.173417 & 28.596000 & SAINT CATHERINE & 61 & - \\
\hline 836 & 771490 & SWFWMD & Water Well & -82.176806 & 28.579389 & SAINT CATHERINE & 67 & - \\
\hline 837 & 750880 & SWFWMD & Water Well & -82.178319 & 28.646983 & WAHOO & 56 & - \\
\hline 838 & 762386 & SWFWMD & Water Well & -82.178894 & 28.602392 & SAINT CATHERINE & 63 & - \\
\hline 839 & 760501 & SWFWMD & Water Well & -82.180944 & 28.566611 & SAINT CATHERINE & 61 & - \\
\hline 840 & 771644 & SWFWMD & Water Well & -82.181631 & 28.576542 & SAINT CATHERINE & 69 & - \\
\hline 841 & 759824 & SWFWMD & Water Well & -82.185472 & 28.557111 & SAINT CATHERINE & 66 & - \\
\hline 842 & 764225 & SWFWMD & Water Well & -82.185611 & 28.594556 & SAINT CATHERINE & 61 & - \\
\hline 843 & 764763 & SWFWMD & Water Well & -82.185806 & 28.553861 & SAINT CATHERINE & 55 & - \\
\hline 844 & 759700 & SWFWMD & Water Well & -82.188583 & 28.527167 & SAINT CATHERINE & 64 & - \\
\hline 845 & 757296 & SWFWMD & Water Well & -82.189944 & 28.603056 & SAINT CATHERINE & 63 & - \\
\hline 846 & 751577 & SWFWMD & Water Well & -82.194967 & 28.647047 & WAHOO & 51 & - \\
\hline 847 & 775724 & SWFWMD & Water Well & -82.206889 & 28.503639 & SAINT CATHERINE & 75 & - \\
\hline 848 & 768792 & SWFWMD & Water Well & -82.207944 & 28.611333 & SAINT CATHERINE & 77 & - \\
\hline 849 & 773542 & SWFWMD & Water Well & -82.210722 & 28.608194 & SAINT CATHERINE & 62 & - \\
\hline 850 & 776919 & SWFWMD & Water Well & -82.271806 & 28.662944 & NOBLETON & 40 & - \\
\hline 851 & 767258 & SWFWMD & Water Well & -82.271806 & 28.528306 & BROOKSVILLE SE & 138 & - \\
\hline
\end{tabular}


FLORIDA GEOLOGICAL SURVEY

\begin{tabular}{|c|c|c|c|c|c|c|c|c|}
\hline $\begin{array}{l}\text { Map } \\
\text { ID }\end{array}$ & Well Label & Data Source & Sample Type & Longitude & Latitude & 24K Quad & $\begin{array}{c}\text { Elevation } \\
(\mathrm{ft})\end{array}$ & $\begin{array}{c}\text { Total } \\
\text { Depth }(\mathrm{ft})\end{array}$ \\
\hline 852 & 777569 & SWFWMD & Water Well & -82.272111 & 28.510944 & BROOKSVILLE SE & 105 & - \\
\hline 853 & 760568 & SWFWMD & Water Well & -82.295528 & 28.534806 & BROOKSVILLE SE & 68 & - \\
\hline 854 & 754602 & SWFWMD & Water Well & -82.296111 & 28.539944 & BROOKSVILLE SE & 66 & - \\
\hline 855 & 754481 & SWFWMD & Water Well & -82.300333 & 28.652528 & NOBLETON & 111 & - \\
\hline 856 & 762870 & SWFWMD & Water Well & -82.318472 & 28.516389 & BROOKSVILLE SE & 105 & - \\
\hline 857 & 771213 & SWFWMD & Water Well & -82.319703 & 28.610403 & BROOKSVILLE SE & 130 & - \\
\hline 858 & 761829 & SWFWMD & Water Well & -82.323858 & 28.589569 & BROOKSVILLE SE & 74 & - \\
\hline 859 & 750638 & SWFWMD & Water Well & -82.327794 & 28.500586 & BROOKSVILLE SE & 209 & - \\
\hline 860 & 784099 & SWFWMD & Water Well & -82.343300 & 28.534319 & BROOKSVILLE SE & 87 & - \\
\hline 861 & 777278 & SWFWMD & Water Well & -82.348306 & 28.531806 & BROOKSVILLE SE & 117 & - \\
\hline 862 & 771441 & SWFWMD & Water Well & -82.352833 & 28.595944 & BROOKSVILLE SE & 80 & - \\
\hline 863 & 764564 & SWFWMD & Water Well & -82.355222 & 28.735806 & NOBLETON & 79 & - \\
\hline 864 & 768356 & SWFWMD & Water Well & -82.358583 & 28.589194 & BROOKSVILLE SE & 127 & - \\
\hline 865 & 755832 & SWFWMD & Water Well & -82.362667 & 28.733167 & NOBLETON & 85 & - \\
\hline 866 & 768670 & SWFWMD & Water Well & -82.408069 & 28.534681 & BROOKSVILLE & 89 & - \\
\hline 867 & 758245 & SWFWMD & Water Well & -82.459528 & 28.522778 & BROOKSVILLE & 78 & - \\
\hline 868 & 765234 & SWFWMD & Water Well & -82.462528 & 28.504417 & BROOKSVILLE & 80 & - \\
\hline 869 & 774257 & SWFWMD & Water Well & -82.470564 & 28.502886 & BROOKSVILLE & 71 & - \\
\hline 870 & 755566 & SWFWMD & Water Well & -82.485367 & 28.512144 & BROOKSVILLE & 84 & - \\
\hline 871 & 765957 & SWFWMD & Water Well & -82.486889 & 28.525056 & BROOKSVILLE & 97 & - \\
\hline 872 & 755638 & SWFWMD & Water Well & -82.495025 & 28.651256 & BROOKSVILLE NW & 74 & - \\
\hline 873 & 766519 & SWFWMD & Water Well & -82.495472 & 28.653194 & BROOKSVILLE NW & 85 & - \\
\hline 874 & 780930 & SWFWMD & Water Well & -82.497417 & 28.512028 & BROOKSVILLE & 58 & - \\
\hline 875 & 759736 & SWFWMD & Water Well & -82.498083 & 28.635611 & BROOKSVILLE NW & 88 & - \\
\hline 876 & 765054 & SWFWMD & Water Well & -82.498472 & 28.655944 & BROOKSVILLE NW & 68 & - \\
\hline 877 & 765318 & SWFWMD & Water Well & -82.291778 & 28.996342 & STOKES FERRY & 56 & - \\
\hline 878 & 778336 & SWFWMD & Water Well & -82.302597 & 28.890147 & STOKES FERRY & 43 & - \\
\hline 879 & 760367 & SWFWMD & Water Well & -82.361153 & 28.992236 & STOKES FERRY & 41 & - \\
\hline 880 & 775653 & SWFWMD & Water Well & -82.364806 & 28.901056 & STOKES FERRY & 47 & - \\
\hline 881 & 772025 & SWFWMD & Water Well & -82.367778 & 28.883667 & STOKES FERRY & 62 & - \\
\hline 882 & 770552 & SWFWMD & Water Well & -82.370139 & 28.963625 & STOKES FERRY & 51 & - \\
\hline 883 & 778440 & SWFWMD & Water Well & -82.370733 & 28.935908 & STOKES FERRY & 44 & - \\
\hline 884 & 751336 & SWFWMD & Water Well & -82.377464 & 28.930547 & HOLDER & 60 & - \\
\hline 885 & 769356 & SWFWMD & Water Well & -82.378619 & 28.968356 & HOLDER & 39 & - \\
\hline 886 & 755448 & SWFWMD & Water Well & -82.405500 & 28.923694 & HOLDER & 70 & - \\
\hline 887 & 758042 & SWFWMD & Water Well & -82.408611 & 28.970306 & HOLDER & 54 & - \\
\hline 888 & 750470 & SWFWMD & Water Well & -82.413225 & 28.951361 & HOLDER & 92 & - \\
\hline 889 & 771037 & SWFWMD & Water Well & -82.423500 & 28.962861 & HOLDER & 74 & - \\
\hline 890 & 775371 & SWFWMD & Water Well & -82.424194 & 28.975083 & HOLDER & 64 & - \\
\hline 891 & 760818 & SWFWMD & Water Well & -82.433139 & 28.891222 & HOLDER & 101 & - \\
\hline 892 & 769728 & SWFWMD & Water Well & -82.486389 & 28.932056 & HOLDER & 76 & - \\
\hline 893 & 753577 & SWFWMD & Water Well & -82.492661 & 28.917717 & HOLDER & 75 & - \\
\hline 894 & 774397 & SWFWMD & Water Well & -82.497711 & 28.901492 & HOLDER & 94 & - \\
\hline 895 & 768173 & SWFWMD & Water Well & -82.305247 & 28.897197 & STOKES FERRY & 44 & - \\
\hline 896 & 772644 & SWFWMD & Water Well & -82.359581 & 28.903339 & STOKES FERRY & 55 & - \\
\hline 897 & 774494 & SWFWMD & Water Well & -82.360917 & 28.881278 & STOKES FERRY & 65 & - \\
\hline 898 & 777823 & SWFWMD & Water Well & -82.367750 & 28.931389 & STOKES FERRY & 42 & - \\
\hline 899 & 763235 & SWFWMD & Water Well & -82.380306 & 28.879583 & HOLDER & 52 & - \\
\hline 900 & 771036 & SWFWMD & Water Well & -82.413194 & 28.944111 & HOLDER & 45 & - \\
\hline 901 & 755498 & SWFWMD & Water Well & -82.433500 & 28.879389 & HOLDER & 119 & - \\
\hline 902 & 755696 & SWFWMD & Water Well & -82.459075 & 28.940014 & HOLDER & 90 & - \\
\hline
\end{tabular}

NOTE: Elevations for the Southwest Florida Water Management District (SWFWMD) wells used in this project were acquired from an FGS-generated Digital Elevation Model (DEM). 